This document is confidential and is proprietary to the American Chemical Society and its authors. Do not copy or disclose without written permission. If you have received this item in error, notify the sender and delete all copies.

\title{
A SCAFFOLD SIMPLIFICATION STRATEGY LEADS TO A NOVEL GENERATION OF DUAL HIV AND ENTEROVIRUS-A71 ENTRY INHIBITORS
}

\begin{tabular}{|c|c|}
\hline Journal: & Journal of Medicinal Chemistry \\
\hline Manuscript ID & Draft \\
\hline Manuscript Type: & Article \\
\hline $\begin{array}{r}\text { Date Submitted by the } \\
\text { Author: }\end{array}$ & $\mathrm{n} / \mathrm{a}$ \\
\hline Complete List of Authors: & $\begin{array}{l}\text { Martínez-Gualda, Belén; Katholieke Universiteit Leuven Rega Institute for } \\
\text { Medical Research } \\
\text { Sun, Liang; Katholieke Universiteit Leuven Rega Institute for Medical } \\
\text { Research } \\
\text { Martí-Marí, Olaia; Consejo Superior de Investigaciones Cientificas, } \\
\text { QUIMICA MEDICA } \\
\text { Noppen, Sam; KU Leuven Rega Institute for Medical Research } \\
\text { Abdelnabi, Rana ; KU Leuven Rega Institute for Medical Research } \\
\text { Bator, Carol M.; Pennsylvania State University College of Medicine } \\
\text { Quesada, Ernesto; Consejo Superior de Investigaciones Cientificas, } \\
\text { QUIMICA MEDICA } \\
\text { Delang, Leen; Katholieke Universiteit Leuven Rega Institute for Medical } \\
\text { Research } \\
\text { Mirabelli, Carmen; Pennsylvania State University College of Medicine } \\
\text { Lee, Hyunwook; Pennsylvania State University College of Medicine } \\
\text { Schols, Dominique; Katholieke Universiteit Leuven Rega Institute for } \\
\text { Medical Research, } \\
\text { Neyts, Johan; KU Leuven } \\
\text { Hafenstein, Susan; Pennsylvania State University College of Medicine } \\
\text { Camarasa, María-José; Instituto de Quimica Medica, Medicinal Chemistry } \\
\text { III } \\
\text { Gago, Federico; University of Alcala, Biomedical Sciences } \\
\text { San-Felix, Ana; Consejo Superior de Investigaciones Cientificas, } \\
\text { QUIMICA MEDICA }\end{array}$ \\
\hline
\end{tabular}

\section{SCHOLARONE ${ }^{\text {m }}$ Manuscripts}




\title{
A SCAFFOLD SIMPLIFICATION STRATEGY
}

\section{LEADS TO A NOVEL GENERATION OF DUAL}

\section{HIV AND ENTEROVIRUS-A71 ENTRY}

\section{INHIBITORS}

\author{
Belén Martínez-Gualda ${ }^{1 *}$, Liang Sun ${ }^{2}$, Olaia Martí-Marí ${ }^{1}$, Sam Noppen $^{2}$, Rana Abdelnabi $^{2}$, \\ Carol M. Bator ${ }^{4}$, Ernesto Quesada ${ }^{1}$,Leen Delang 2 , Carmen Mirabelli ${ }^{2 \&}$, Hyunwook Lee ${ }^{4}$, \\ Dominique Schols ${ }^{2}$, Johan Neyts ${ }^{2}$, Susan Hafenstein ${ }^{4,5}$, María-José Camarasa ${ }^{1}$, \\ Federico Gago ${ }^{3}$, Ana San-Félix*1 \\ ${ }^{1}$ Instituto de Química Médica (IQM-CSIC), 28006 Madrid, Spain
}

\begin{abstract}
${ }^{2}$ University of Leuven, Department of Microbiology and Immunology, Rega Institute for Medical Research, Laboratory of Virology and Chemotherapy, B-3000 Leuven, Belgium

${ }^{3}$ Departamento de Ciencias Biomédicas y Unidad Asociada IQM-UAH, Universidad de Alcalá, E-28805 Alcalá de Henares, Madrid, Spain

${ }^{4}$ Department of Biochemistry and Molecular Biology, Huck Institutes of the Life Sciences, the Pennsylvania State University, University Park, Pennsylvania, USA

5 Department of Medicine, the Pennsylvania State University College of Medicine, Hershey, Pennsylvania, USA
\end{abstract}

Keywords: Antivirals; HIV; EV71; Tryptophan; indole; palladium-catalyzed C-H activation 


\begin{abstract}
The entry-fusion process is one of the most promising targets to develop new classes of effective anti-HIV drugs but currently there are only two inhibitors of this class approved by the FDA and none of them binds to the envelope glycoprotein gp120. The situation is even worse for enterovirus EV71 infection for which no antiviral therapies are available. We describe here the discovery of potent entry dual inhibitors of HIV and EV71. These compounds contain in their structure 3 or 4 tryptophan (Trp) residues linked to a central scaffold. Critical for anti-HIV/EV71 activity is the presence of extra phenyl rings, bearing one or two carboxylates, at the $\mathrm{C} 2$ position of the indole ring of each Trp residue. The most potent derivatives, 22 and 30, inhibit early steps of the replicative cycles of HIV-1 and EV-A71 by interacting with their respective viral surfaces (glycoprotein gp120 of HIV and 5-fold axis of the EV-A71 capsid). The high potency, low toxicity, facile chemical synthesis and great opportunities for chemical optimization make them useful prototypes for future medicinal chemistry studies.
\end{abstract}

\title{
INTRODUCTION
}

Human immunodeficiency virus (HIV) is a retrovirus that infects immune cells within the body. Without treatment the infection can result in the development of Acquired Immune Deficiency Syndrome (AIDS) and death. HIV infection affects more than 30 million people worldwide and caused about 1 million deaths in $2018 .{ }^{1}$ Current antiretroviral therapy consists on more than 30 approved drugs or regimens. Although this therapy has significantly improved the quality of life of infected people, there is still no cure for the HIV infection. ${ }^{2-7}$ Moreover, the combined therapy is lifelong, expensive, associated with significant side-effects/resistance, and not universally available in all regions of the world. ${ }^{1,8-12}$ These limitations highlight the need for new lead compounds and/or novel therapeutic approaches to fight HIV infection. ${ }^{13-17}$ In this regard, the initial steps in the HIV replicative cycle (entry and/or fusion with the host cells) are 
very attractive targets. ${ }^{18-23}$ Despite their intrinsic interest there are only two entry inhibitors approved by FDA, namely Fuzeon ${ }^{24,25}$, which targets the envelope glycoprotein gp41, and Maraviroc ${ }^{26}$, which targets the host cell receptor CCR5.

We have previously reported a family of tryptophan (Trp) dendrimers, exemplified by 1 (Fig. 1), that inhibit an early step in the replicative cycle of HIV by interacting with the gp120 glycoprotein of the viral envelope. ${ }^{27}$ Interestingly, these compounds also proved to be potent inhibitors of the replication of the unrelated enterovirus 71 (EV71), ${ }^{28}$ the virus responsible for most of the severe forms of hand, foot and mouth disease (HFMD). This virus is associated with neurological/cardiopulmonary complications and mortality in children below 5 years old. ${ }^{29-33}$ In the last two decades, the increasing number of EV71 cases and the spread of the virus across Asia, followed by case reports in Spain, France, Germany and other European countries, have raised major concerns about its pandemic potential. ${ }^{34-36}$

Although a sub-genogroup C4 EV71-inactivated vaccine has been recently approved in China no antiviral therapies are so far, available for the prevention or treatment of EV71 infection. ${ }^{37,38}$ Therefore, the development of effective and specific antiviral drugs is urgently needed..$^{39,40}$

Remarkably, dendrimer $\mathbf{1}$ inhibits not only the laboratory BrCr strain of EV-A71 but also a large panel of clinical isolates (belonging to each of the genogroups) in the low-nanomolar/highpicomolar range. ${ }^{28}$ Recently, it was demonstrated that $\mathbf{1}$ inhibits an early step in the replicative cycle of EV-A71 by targeting residues of the structural viral protein VP1, particularly the region that forms the 5-fold axis of the viral capsid, and thereby blocking the binding of the virus to the host cell. ${ }^{41}$

With respect to the SAR studies, modifications have been made in the central core, arms and periphery of the prototype $1 .^{27,28,42,43}$ All of these modifications led to the conclusion that a 
multivalent presentation of Trps, with their respective indole side chain and free carboxylates, is required to preserve the antiviral activity against both HIV and EV-A71.

The prototype 1 has a too high molecular weight (MW: $3576 \mathrm{Da}$ ) for drug development purposes. The aim of the present work is to develop compounds with smaller size retaining the same level of antiviral potency.

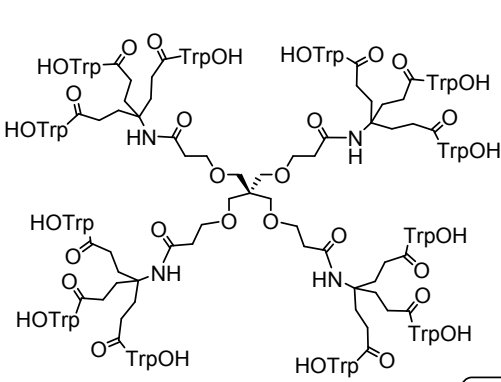

MADAL-385 (1)

$\mathrm{HIV}\left\{\mathrm{EC}_{50}: 2.3 \pm 0.3 \mu \mathrm{M}\right.$

HIV $\left\{\mathrm{CC}_{50}>100 \mu \mathrm{M}\right.$

EV71 $\left\{\begin{array}{l}\mathrm{EC}_{50}: 0.3 \pm 0.07 \mu \mathrm{M} \\ \mathrm{CC}_{50}: 30.0 \pm 2.5 \mu \mathrm{M}\end{array}\right.$

Clinical isolates $\mathrm{EC}_{50}: 0.0002-0.001 \mu \mathrm{M}$

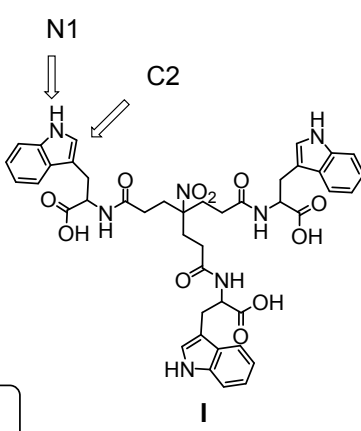

HIV: $\mathrm{EC}_{50}>100 \mu \mathrm{M}$

$\mathrm{EV} 71: \mathrm{EC}_{50}>120 \mu \mathrm{M}$

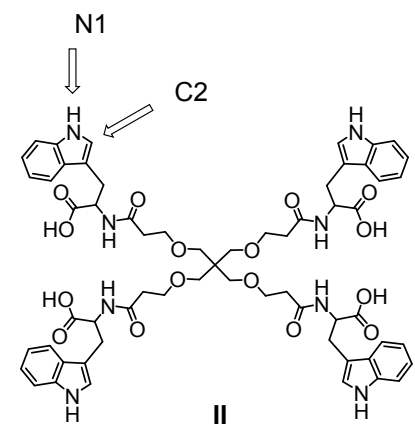

HIV: $\mathrm{EC}_{50}>250 \mu \mathrm{M}$

EV71: $\mathrm{EC}_{50}>100 \mu \mathrm{M}$

Figure 1. Structures of the prototype pentaerythritol derivative MADAL-385 (1) and "truncated" analogues I and II.

With this aim, a scaffold simplification strategy was applied and "truncated" analogues (I and II) of $\mathbf{1}$, with only 3 or 4 Trps respectively (Figure 1), were firstly synthesized. However, as it will be later discussed in the Antiviral Evaluation section, both compounds resulted inactive against HIV and EV-A71.

Next, we decided to "decorate" I and II with moieties that could potentially participate in extra interactions with protein residues in the corresponding binding site. Phenyl rings functionalized with carboxylic groups were preferentially chosen because according to previous SAR studies, both aromaticity and negatively charged moieties are beneficial for anti-HIV and anti-EV-A71 
activity. ${ }^{42}$ Moreover, these functionalized phenyl rings could potentially participate in hydrogen bonding and/or hydrophobic/aromatic interactions with protein residues of the corresponding binding site. To introduce these substituents, we exploited the particular reactivity of the indole ring of Trp. ${ }^{44}$ Thus, the $\mathrm{C} 2$ and N1 positions of the indole moiety were chosen as attachment points (Figure 1). Hereafter, we describe the synthesis, antiviral activities against HIV and EV71, and structure-activity relationships of this new generation of compounds.

\section{RESULTS AND DISCUSSION}

\section{Chemistry}

As mentioned, we designed truncated analogues of the prototype with extra functionalized aromatic rings attached to the $\mathrm{C} 2$ and $\mathrm{N} 1$ positions of the indole ring. We started with the synthesis of the tripodal derivatives 14-22 (Scheme 1), with functionalized phenyl rings on the C2 position of the indole ring of the three Trp residues. The synthesis of these compounds takes advantage of the methodology developed by Prof. Lavilla's group which allows the direct C2 arylation of Trp and proteins containing this amino acid. ${ }^{45,46}$ The reaction involves the simultaneous formation of new $\mathrm{C}-\mathrm{C}$ bonds through a metal-catalyzed (Pd II) cross-coupling reaction. 


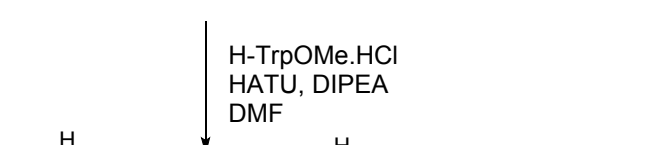

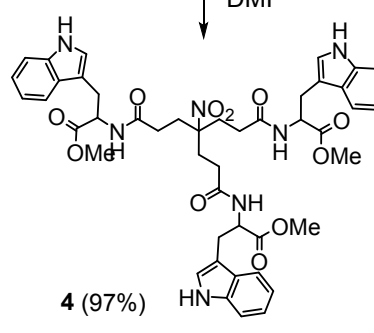

$\mid \begin{aligned} & \text { 1. } \mathrm{LiOH}, \mathrm{THF} / \mathrm{H}_{2} \mathrm{O} \\ & \text { 2. } \mathrm{HCl} 1 \mathrm{M}\end{aligned}$

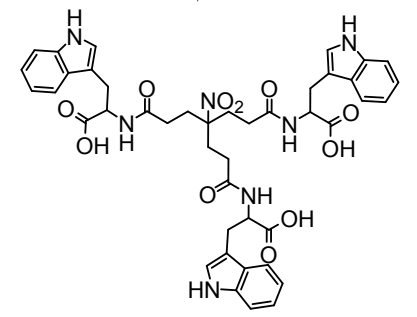

I (quant)
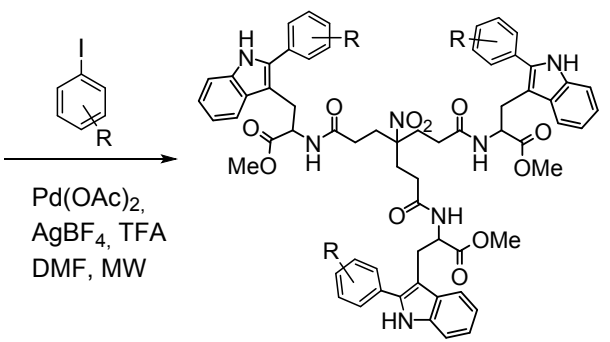

$5, \mathrm{R}=\mathrm{H}(57 \%)$

6, $\mathrm{R}=2-\mathrm{F}(29 \%)$

$7, \mathrm{R}=4-\mathrm{NO}_{2}(47 \%)$

$8, R=4-B r(37 \%)$

9, $\mathrm{R}=4-\mathrm{CF}_{3}(33 \%)$

$10, \mathrm{R}=4$-OMe $(38 \%)$

11, $\mathrm{R}=3$-COOMe $(38 \%)$

12, $\mathrm{R}=4$-COOMe $(37 \%)$

13, $R=3,5$-COOMe $(35 \%)$

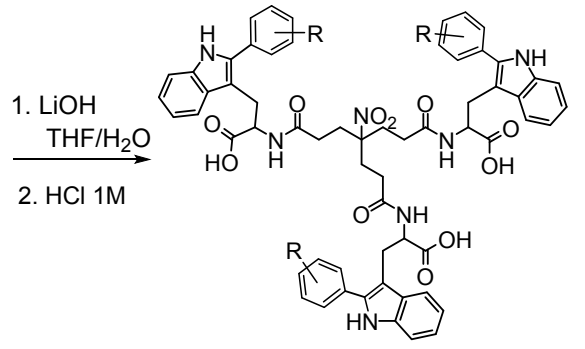

$14, \mathrm{R}=\mathrm{H}$ (quant) $15, R=2-F$ (quant) $16, \mathrm{R}=4-\mathrm{NO}_{2}$ (quant) $17, \mathrm{R}=4-\mathrm{Br}$ (quant) $18, \mathrm{R}=4-\mathrm{CF}_{3}$ (quant) 19, $\mathrm{R}=4-\mathrm{OMe}$ (quant) 20, $\mathrm{R}=3-\mathrm{COOH}$ (quant) 21, $\mathrm{R}=4-\mathrm{COOH}$ (quant) 22, $\mathrm{R}=3,5-\mathrm{COOH}$ (quant)

Scheme 1. Synthesis of the tripodal derivatives I and 14-22.

The synthesis started with the commercially available scaffold 2. Removal of the $t$-butyl protecting groups of $\mathbf{2}$, followed by condensation of the resulting triacid $(\mathbf{3})^{47}$ with $\mathrm{OMe}$ protected $\operatorname{Trp}(\mathrm{H}-\operatorname{TrpOMe} \cdot \mathrm{HCl})$ in the presence of HATU, as the coupling reagent, and DIPEA as the base, gave intermediate $4(97 \%)$. The simultaneous chemoselective arylation on the $\mathrm{C} 2$ position of the three indole moieties of $\mathbf{4}$ was first attempted with phenyl iodide following Lavilla's conditions. ${ }^{45,46}$ Overall, a mixture of 5 mol\% $\mathrm{Pd}(\mathrm{OAc})_{2}, \operatorname{AgBF}_{4}(3 \mathrm{eq}), \mathrm{TFA}(3 \mathrm{eq})$, phenyl iodide (3 eq) in $N, N^{\prime}$-dimethylformamide (DMF) was microwave (MW) irradiated at 80 ${ }^{\circ} \mathrm{C}$ for 15 min. However, HPLC analysis revealed that only $5 \%$ of the desired compound 5 was present in the reaction mixture. The less lipophilic peaks were attributed to partial reaction in only one or two of the three Trps present in the starting compound 4. However, the use of higher 
temperatures $\left(120^{\circ} \mathrm{C}\right)$, longer reaction times $(30 \mathrm{~min})$, excess of aryl iodide and $\mathrm{AgBF}_{4}$ ( 2 eq for each Trp), allowed to finally obtain the desired methyl ester intermediate 5 with $57 \%$ yield. Saponification of the protecting ester moieties using $\mathrm{LiOH} \cdot \mathrm{H}_{2} \mathrm{O}$ afforded the final compound $\mathbf{1 4}$ in quantitative yield (Scheme 1).

Next, and based on the good results obtained with phenyl iodide, the same synthetic methodology was applied with the other aryl iodides to afford compounds 6 (29\%), 7 (47\%), 8 (37\%), $9(33 \%), 10(38 \%), 11(38 \%), 12(37 \%)$ and $13(35 \%)$. These reactions proceed in remarkably short times (30 minutes), are completely selective (only reaction at $\mathrm{C} 2$ was observed) and compatible with ambient air/moisture. Methyl ester deprotection $\left(\mathrm{LiOH} / \mathrm{H}_{2} \mathrm{O}\right)$ of $\mathbf{6}-\mathbf{1 3}$ afforded the final tripodal derivatives $\mathbf{1 5 - 2 2}$ in quantitative yields. In addition, the unsubstituted Trp derivative I was also prepared by deprotection of 4 .

The synthesis of the tetrapodal derivatives 28-30 was accomplished following a similar methodology as described for the tripodal series (Scheme 2). Again, the key step of the reaction involves the simultaneous formation of new $\mathrm{C}-\mathrm{C}$ bonds through a metal-catalyzed (Pd II) crosscoupling reaction. In this case, the tetrapodal Trp derivative $\mathbf{2 4}$ was used as the starting material. In turn, this compound was obtained by condensation of the tetraacid $\mathbf{2 3}^{48,49}$ with OMe-protected $\operatorname{Trp}(\mathrm{H}-\mathrm{TrpOMe} \cdot \mathrm{HCl})$ in the presence of HATU as the coupling reagent and DIPEA as the base. Reaction of $\mathbf{2 4}$ with the corresponding aryl iodide, under the previously mentioned optimized conditions, afforded intermediates 25 (39\%), 26 (32\%) and 27 (26\%), the subsequent deprotection $\left(\mathrm{LiOH} / \mathrm{H}_{2} \mathrm{O}\right)$ gave the desired final compounds $\mathbf{2 8}-\mathbf{3 0}$ in quantitative yields. The $\mathrm{C} 2$ unsubstituted Trp derivative II was also prepared by deprotection $\left(\mathrm{LiOH} / \mathrm{H}_{2} \mathrm{O}\right)$ of $\mathbf{2 4}$. 


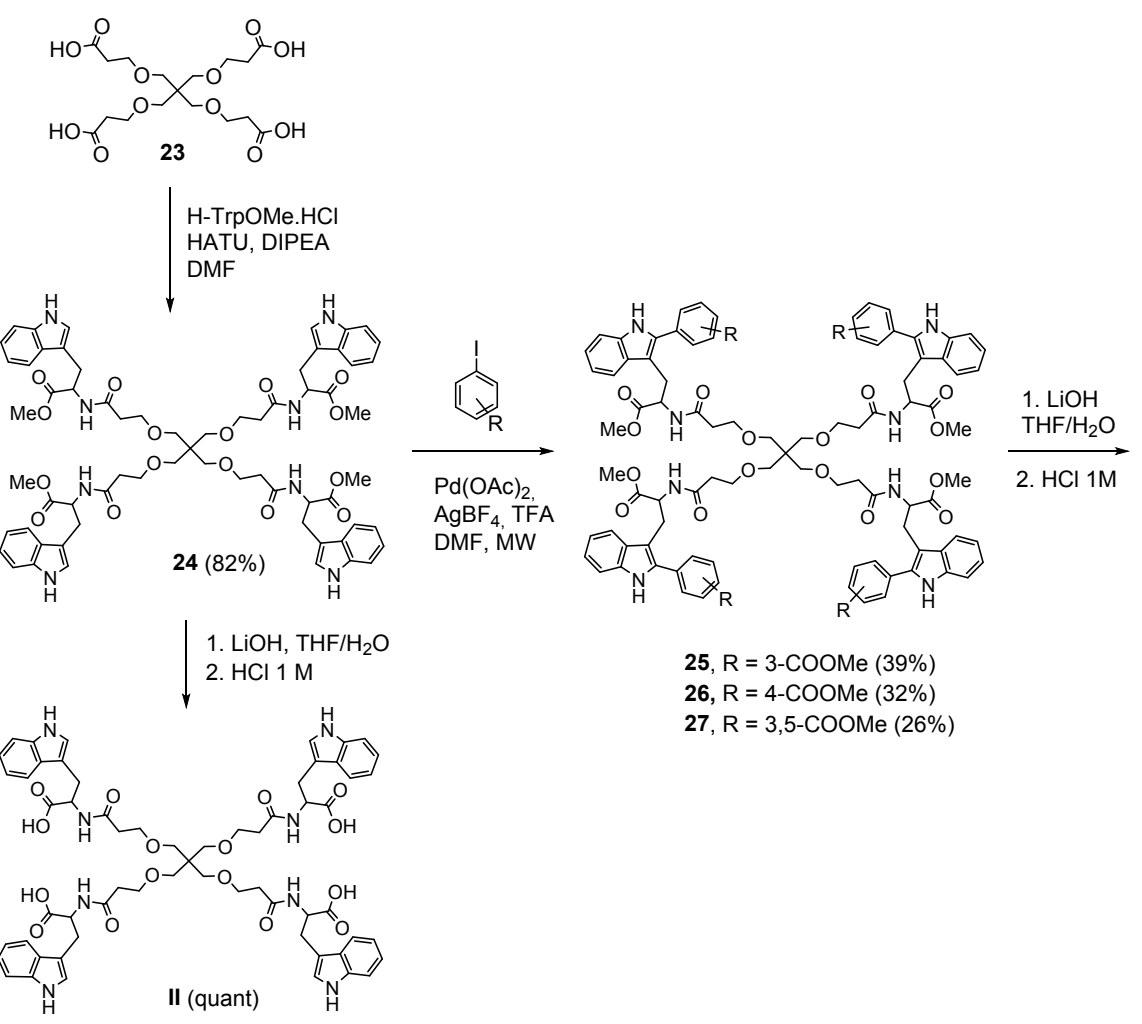

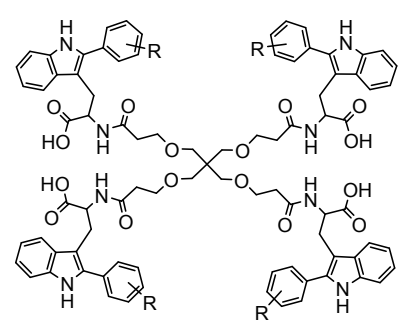

28, $\mathrm{R}=3-\mathrm{COOH}$ (quant) 29, $\mathrm{R}=4-\mathrm{COOH}$ (quant) $30, \mathrm{R}=3,5-\mathrm{COOH}$ (quant)

Scheme 2. Synthesis of the tetrapodal derivatives II and 28-30.

Finally, to complete the SAR studies functionalized aromatic substituents at the N1 position of the indole moiety were introduced. Starting from 4, the N1-substituted analogues 34-36 were synthesized by reaction with the corresponding benzyl bromides, in the presence of $\mathrm{Cs}_{2} \mathrm{CO}_{3}$ at 80 ${ }^{\circ} \mathrm{C}$ followed by subsequent deprotection $\left(\mathrm{LiOH} / \mathrm{H}_{2} \mathrm{O}\right)$ of intermediates 31-33 (Scheme 3). The same synthetic methodology was applied to the synthesis of the tetrapodal analogue $\mathbf{3 8}$ which was obtained in $31 \%$ overall yield (Scheme 3 ). 

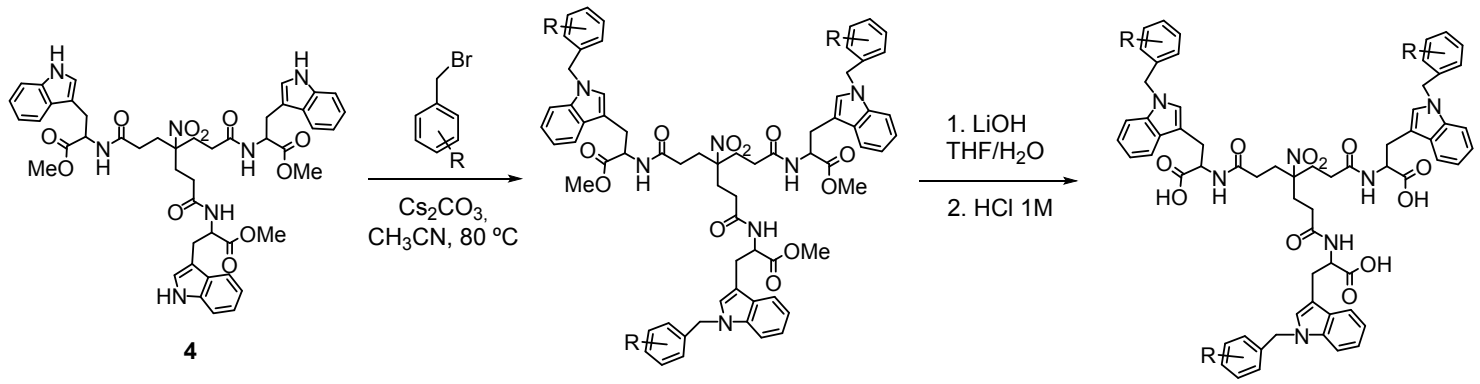

$31, \mathrm{R}=\mathrm{H}(33 \%)$ $32, R=4-F(42 \%)$

33, $R=4-$ COOMe $(33 \%)$

34, $\mathrm{R}=\mathrm{H}$ (quant) $35, R=4-F$ (quant) 36, $\mathrm{R}=4-\mathrm{COOH}$ (quant)
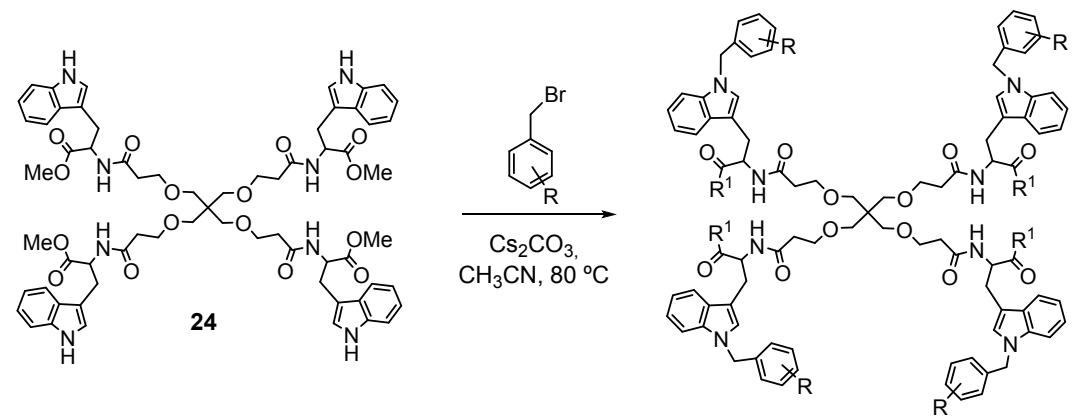

37, $\left.\mathrm{R}=4-\mathrm{COOMe} ; \mathrm{R}^{1}=\mathrm{OMe}(31 \%)\right)$ 1. $\mathrm{LiOH}, \mathrm{THF} / \mathrm{H}_{2} \mathrm{O}$

38, $\mathrm{R}=4-\mathrm{COOH} ; \mathrm{R}^{1}=\mathrm{OH}$ (quant) 2 . $\mathrm{HCl} 1 \mathrm{M}$

Scheme 3. Synthesis of the N1 substituted tripodal (34-36) and tetrapodal (38) derivatives.

As will be discussed later, compounds 22 and 30, with isophthaloyl moieties at $\mathrm{C} 2$, were promising as anti-HIV and EV71 agents. To have access to higher amount of these compounds for further biological studies and structural modifications we explored a novel convergent synthetic strategy (Scheme 4) in which a C-2 arylated Trp derivative 41, with a free amino group, was used as a key common intermediate. 


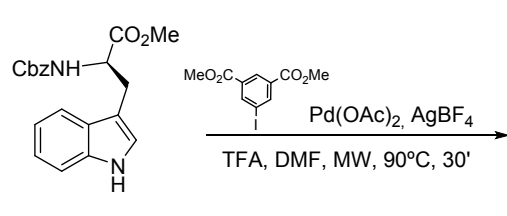

39

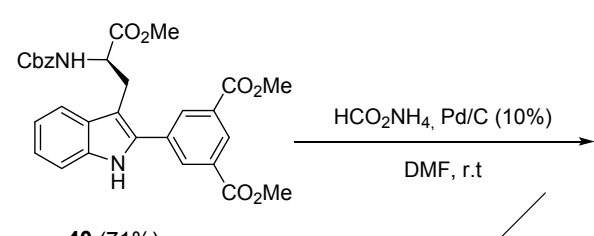

$40(71 \%)$

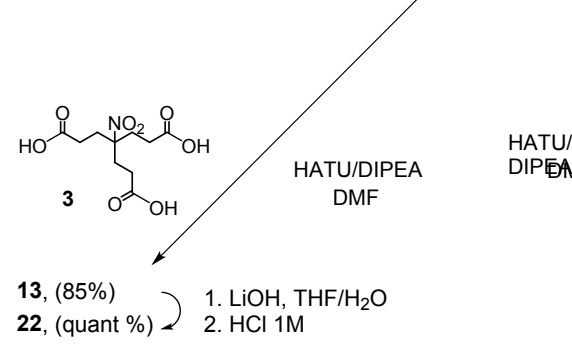

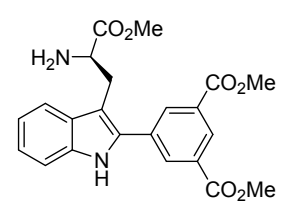

$41(89 \%)$

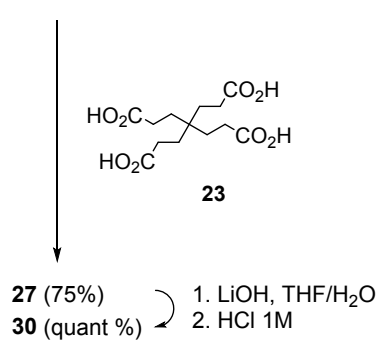

Scheme 4. Alternative synthetic route for the synthesis of $\mathbf{2 2}$ and $\mathbf{3 0 .}$

The synthesis of 41 started with the commercially available $N^{\alpha}-\mathrm{CBz}$ tryptophan methyl ester (39) that was C-2 arylated with dimethyl 5-iodoisophthlate. The reaction was carried out in DMF as before, $5 \mathrm{~mol} \% \mathrm{Pd}(\mathrm{OAc})_{2}, \mathrm{AgBF}_{4}, \mathrm{TFA}$, microwave irradiation during $30 \mathrm{~min}$ at $120{ }^{\circ} \mathrm{C}$, to afford intermediate 40 in good yield (71\%). Subsequent carboxybenzyl (CBz) deprotection, was attempted first using hydrogen and $10 \% \mathrm{Pd} / \mathrm{C}$. However, the starting compound was recovered intact. Instead, catalytic transfer hydrogenation using dry ammonium formate and $10 \% \mathrm{Pd} / \mathrm{C}^{50}$ afforded the amino intermediate 41 in very good yield (89\%). Further attachment of 41, through the formation of amide bonds, to the tripodal (3) or tetrapodal (23) central scaffols afforded intermediates $13(85 \%)$ and $27(75 \%)$ respectively. Finally, methyl esther deprotection $\left(\mathrm{LiOH} / \mathrm{H}_{2} \mathrm{O}\right)$ afforded the desired final compounds 22 and 30 (structure in Scheme 1) in quantitative yields.

Compared to the divergent approach (Scheme 1), this convergent methodology enables de synthesis of $\mathbf{2 2}$ and $\mathbf{3 0}$ in a very simple and straightforward form. Moreover, the global yields of 22 and 30 improved considerably (54\% versus $34 \%$ for 22 ) and (47\% versus $21 \%$ for $\mathbf{3 0}$ ). Based 
on these results we consider this second synthetic strategy as a general and more efficient approach for the synthesis of this type of tricyclic and tetracyclic Trp derivatives.

All the synthesized compounds were characterized by ${ }^{1} \mathrm{H}$ and ${ }^{13} \mathrm{C}$ NMR spectroscopies and High Resolution Mass Spectrometry (HRMS).

\section{Antiviral evaluation}

\section{Antiviral activity against HIV}

Compounds substituted at C2 (14-22 and 28-30) and N1 (34-36 and 38) positions of the indole moiety, together with the unsubstituted trimer I and tetramer II, were first evaluated for their inhibitory effects against HIV-1 and HIV-2 replication in cultured CD4 ${ }^{+} \mathrm{T}$ cells (Table 1 ). The antiviral data of the prototype 1, with 12 unsubstituted Trp residues on the periphery, is also included as a reference compound, as well as that of dextran sulfate-5000 (DS-5000) and pradimicin A (PRM-A). DS-5000 is a negatively charged HIV adsorption inhibitor ${ }^{51}$ and PRM-A represents a gp120 carbohydrate-binding entry inhibitor. ${ }^{52}$ These control compounds showed antiviral activities in the range previously reported..$^{51,52}$

As shown in Table 1, the unsubstituted dendrimers I and II did not show any anti-HIV activity up to $100 \mu \mathrm{M}$. Besides, compounds 17 and 19, with 4-Br-phenyl and 4-OMe-phenyl moieties, respectively, at $\mathrm{C} 2$ were also inactive at sub-toxic concentrations. However, compounds 14-16 and 18, bearing phenyl, 2-F-phenyl, 4-NO - -phenyl and 4-CF - phenyl moieties, respectively, at C2 showed modest but significant anti-HIV activity. Although the activity of these compounds was only moderate these data were important because they represented a first hint of activity in this series of compounds. Moreover, and taking into consideration that I and II did not exhibit 
any antiviral activity against HIV, this result suggests that the $\mathrm{C} 2$ substituent may play an important role in the eventual antiviral activity.

Interestingly, the tripodal derivative $\mathbf{2 1}$, with one $\mathrm{COOH}$ substituent in the para position of the phenyl ring $\left(\mathrm{EC}_{50}=2.4 \mu \mathrm{M}\right)$, was as active as the prototype $\left(\mathrm{EC}_{50}=2.3 \mu \mathrm{M}\right)$ while the tripodal derivative 22, with $2 \mathrm{COOHs}$ at positions 3 and 5 of the phenyl ring (isophthaloyl moiety) was even better $\left(\mathrm{EC}_{50}=0.27 \mu \mathrm{M}\right)$. These data clearly demonstrate that the phenyl rings with free carboxylic acids on C2 play an important role in the anti-HIV activity.

Shifting the position of the substituted aromatic ring on the indole side-chain to N1 (compounds 34-36 and 38) led to a substantial decrease of antiviral activity. This effect was especially pronounced when comparing the activity of the pentaerythritol derivatives $\mathbf{2 9}$ and $\mathbf{3 8}$, with para-COOH arylated Trp residues, in $\mathrm{C} 2$ (compound 29) or in $\mathrm{N} 1$ (compound 38) positions. Compound $29\left(\mathrm{EC}_{50}=0.73 \mu \mathrm{M}\right)$ was 3 -fold more active than the prototype $\left(\mathrm{EC}_{50}=2.3 \mu \mathrm{M}\right)$ while 38 was devoid of antiviral activity. This data indicates that the position of the aromatic substituent is also crucial for anti-HIV activity.

Within the series of tetramers (28-30), the most active compound was $\mathbf{3 0}\left(\mathrm{EC}_{50}=0.07 \mu \mathrm{M}\right)$, with two COOHs at positions 3 and 5 of the phenyl ring, followed by $29\left(\mathrm{EC}_{50}=0.73 \mu \mathrm{M}\right)$ and $28\left(\mathrm{EC}_{50}=2.0 \mu \mathrm{M}\right)$, with one $\mathrm{COOH}$ substituent in either the para- or meta- position, respectively, of the phenyl ring.

It should be emphasized that the anti-HIV-1 activity $\left(\mathrm{EC}_{50}=0.07-2.4 \mu \mathrm{M}\right)$ of the trimers $(\mathbf{2 1}$, 22) and tetramers (28-30), bearing at the $\mathrm{C} 2$ position of the indole ring phenyl substituents with one or two COOHs, was above that of the prototype $1\left(\mathrm{EC}_{50}=2.3 \mu \mathrm{M}\right)($ Table 1$)$, although their molecular weight is considerably smaller (approximately 1500 Da versus $3576 \mathrm{Da}$ ). Moreover, the activities displayed by some of these compounds $(\mathbf{2 2}, \mathbf{2 9}$ and $\mathbf{3 0})$ are far below their toxicity 
threshold $\left(\mathrm{CC}_{50}>100 \mu \mathrm{M}\right)$, resulting in compounds with improved selectivity indices $\left(\mathrm{CC}_{50} / \mathrm{EC}_{50}\right.$ ratios, $\mathrm{SI}>370,137$ and 1429 , respectively) with respect to the prototype (SI $>43$ ). Interestingly, tetramer $\mathbf{3 0}$ also shows a 330 -fold improvement of activity against $\mathrm{HIV}-2\left(\mathrm{EC}_{50}=\right.$ $0.02 \mu \mathrm{M})$ with respect to the prototype $\left(\mathrm{EC}_{50}=6.6 \mu \mathrm{M}\right)$.

Table 1. Anti-HIV-1 and anti-HIV-2 activity of the selected group of compounds

\begin{tabular}{|c|c|c|c|c|c|}
\hline Compound & $\begin{array}{c}\mathrm{EC}_{50}^{\mathrm{a}}(\mu \mathrm{M}) \\
\text { HIV-1 }\end{array}$ & $\begin{array}{c}\mathrm{EC}_{50}^{\mathrm{a}}(\mu \mathrm{M}) \\
\text { HIV-2 }\end{array}$ & $\mathrm{CC}_{50}{ }^{\mathrm{b}}(\mu \mathrm{M})$ & $\mathrm{SI}^{\mathrm{c}}$ & $\mathrm{MW}^{\mathrm{d}}(\mathrm{Da})$ \\
\hline 14 & $19 \pm 10$ & $>83$ & $83 \pm 4$ & 4.4 & 1064.14 \\
\hline 15 & $35 \pm 10$ & $>100$ & $>100$ & $>3$ & 1118.12 \\
\hline 16 & $41 \pm 3.8$ & $43 \pm 11$ & $>100$ & $>2$ & 1199.14 \\
\hline 17 & $>30$ & $>30$ & $30 \pm 4.3$ & ND & 1300.83 \\
\hline 18 & $26 \pm 10$ & $68 \pm 6.0$ & $>100$ & $>4$ & 1268.14 \\
\hline 19 & $>9.3$ & $>9.3$ & $9.3 \pm 0.29$ & ND & 1154.22 \\
\hline 20 & $16 \pm 5.7$ & $64 \pm 28$ & $>100$ & $>6$ & 1196.17 \\
\hline 21 & $2.4 \pm 1.3$ & $>71$ & 71 & 29.6 & 1196.17 \\
\hline 22 & $0.27 \pm 0.12$ & $0.63 \pm 0.83$ & $>100$ & $>370$ & 1328.20 \\
\hline 28 & $2.0 \pm 0.56$ & $0.76 \pm 0.53$ & $>100$ & $>50$ & 1649.66 \\
\hline 29 & $0.73 \pm 0.51$ & $0.75 \pm 0.83$ & $>100$ & $>137$ & 1649.66 \\
\hline 30 & $0.07 \pm 0.04$ & $0.02 \pm 0.09$ & $>100$ & $>1429$ & 1825.69 \\
\hline 34 & 49 & 38 & $>100$ & $>2$ & 1106.24 \\
\hline 35 & 43 & 34 & $>100$ & $>2.3$ & 1160.22 \\
\hline 36 & 41 & 47 & $>100$ & $>2.4$ & 1238.27 \\
\hline 38 & $>76$ & $>76$ & 76 & ND & 1705.76 \\
\hline I & $>100$ & $>100$ & $>100$ & ND & 835.86 \\
\hline
\end{tabular}




\begin{tabular}{|c|c|c|c|c|c|}
\hline II & $>250$ & $>250$ & $>250$ & ND & 1169.24 \\
\hline $\mathbf{1}$ & $2.3 \pm 0.30$ & $6.6 \pm 7.7$ & $>100$ & $>43$ & 3575.84 \\
\hline DS-5000 & $0.07 \pm 0.02$ & $0.03 \pm 0.01$ & $>20$ & $>285.7$ & $\sim 5000$ \\
\hline PRM-A & $3.3 \pm 1.2$ & $5.9 \pm 3.7$ & $>100$ & $>30.3$ & 842.80 \\
\hline
\end{tabular}

Data are the mean \pm S.D. of at least 2 to 3 independent experiments ND: No Determined

${ }^{a} \mathrm{EC}_{50}: 50 \%$ Effective concentration, or the concentration required to inhibit HIV-induced cytopathicity by $50 \%$

${ }^{\mathrm{b}} \mathrm{CC}_{50}: 50 \%$ Cytostatic concentration, or the compound concentration required to inhibit $\mathrm{CD}^{+} \mathrm{T}$ cell proliferation by $50 \%$

${ }^{\mathrm{c}}$ SI: Selectivity Index $\left(\mathrm{CC}_{50} / \mathrm{EC}_{50}\right)$

${ }^{\mathrm{d}} \mathrm{MW}$ : Molecular weight of the molecules expressed as Da

\section{Mode of action in the context of HIV infection}

\subsection{Time-of-drug-addition (TOA) experiment}

To determine at which stage of the HIV replication cycle the compounds act, a time-of-drugaddition study ${ }^{53,54}$ was performed with the most potent derivatives 22 and $\mathbf{3 0}$. The HIV entry/fusion inhibitor DS5000 (DS) and the HIV reverse transcriptase inhibitor AZT were used as references. Similar to DS, HIV-1 replication, as measured by p24 antigen production, could be inhibited only if $\mathbf{2 2}$ and $\mathbf{3 0}$ were added to the cells prior to or at the moment of infection. However, addition of AZT, an inhibitor of the reverse transcription step, could be delayed up to $3 \mathrm{~h}$ after infection without loss of the inhibitory activity. These experiments clearly show that the compounds need to be present in $\mathrm{T}$ cell cultures at the start of the virus infection process (binding/adsorption period). Thus, it can be concluded that compounds $\mathbf{2 2}$ and $\mathbf{3 0}$ interfere with early event(s) of the replicative HIV cycle, very likely by inhibiting the entry of HIV into its susceptible human $\mathrm{CD} 4^{+} \mathrm{T}$ cells. 


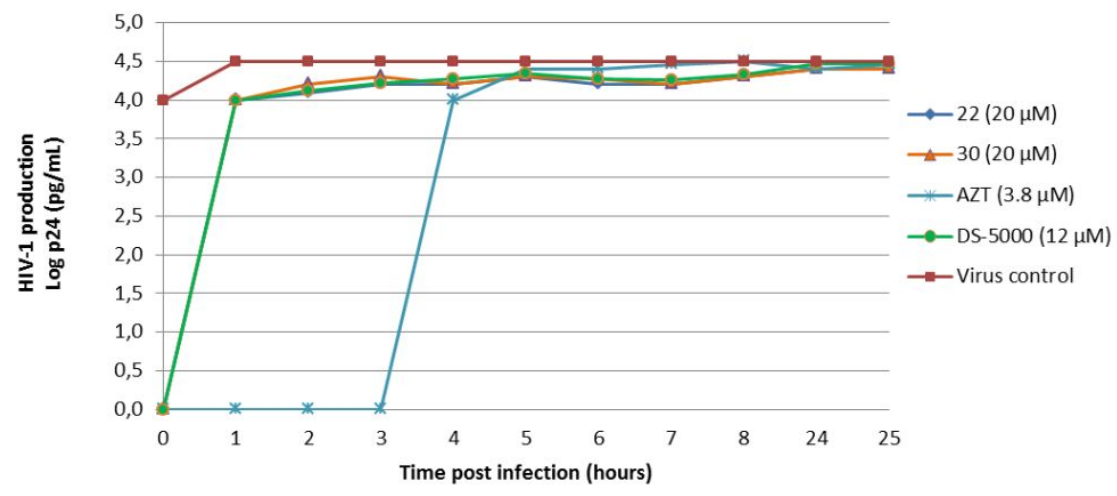

Figure 2. Results of the time-of-drug-addition experiment for compounds 22 and $\mathbf{3 0}$. CD4 ${ }^{+} \mathrm{T}$ cells were treated with the compounds at selected times before, during or after infection with HIV-1. 8h post-infection, cells were harvested and p24 was isolated and quantified by means of RT-qPCR. Data for DS-5000 and AZT are given as reference.

\subsection{Surface plasmon resonance (SPR) analysis (HIV)}

As mentioned, the prototype compound $\mathbf{1}$ inhibits an early step in the replicative cycle of HIV by interacting with the gp120 glycoprotein of the HIV envelope. ${ }^{27}$ To investigate if this glycoprotein is also the potential target of $\mathbf{2 2}$ and 30, a Surface Plasmon Resonance (SPR) experiment was carried out. First, a direct binding experiment, where gp120 was immobilized to the sensorchip, was used. Both compounds dose-dependently bound to immobilized gp120 but we could not fit the experimental data with an existing binding model, nor could steady-state affinity be measured (data not shown).

Because the sensorgrams obtained from these first direct binding experiments were inconclusive, we turned to an indirect experiment in which the inhibitory effects of 22 and $\mathbf{3 0}$ on the heparin-gp120 interaction, were determined. In this experiment heparin, as mimic of the host cell membrane glycosaminoglycans (GAGs), was bound to the sensorchip. ${ }^{55}$ Both 22 and 30 were able to block the binding of gp120 onto immobilized heparin in a dose-dependent manner 
(figs $3 \mathrm{~A}, \mathrm{~B}$ ). Compound $\mathbf{3 0}$ was the most potent inhibitor of gp120-heparin binding with an $\mathrm{IC}_{50}$ of $210.9 \pm 30.2 \mathrm{nM}$ (fig $3 \mathrm{C}$ ). Compound $\mathbf{2 2}$ was approximately 5 times less active than $\mathbf{3 0}\left(\mathrm{IC}_{50}\right.$ $=981.7 \pm 197.0 \mathrm{nM}$ ), which correlates with the weaker anti-HIV-1 activity that was observed in the antiviral assay.

Overall, these data indicate that the observed in vitro anti-HIV activity of the Trp derivatives may be explained by their ability to specifically block the interaction between gp120 and the polysulfated polysaccharides on the host cell membranes. The tetramer $\mathbf{3 0}$ resulted more potent than the trimer 22.
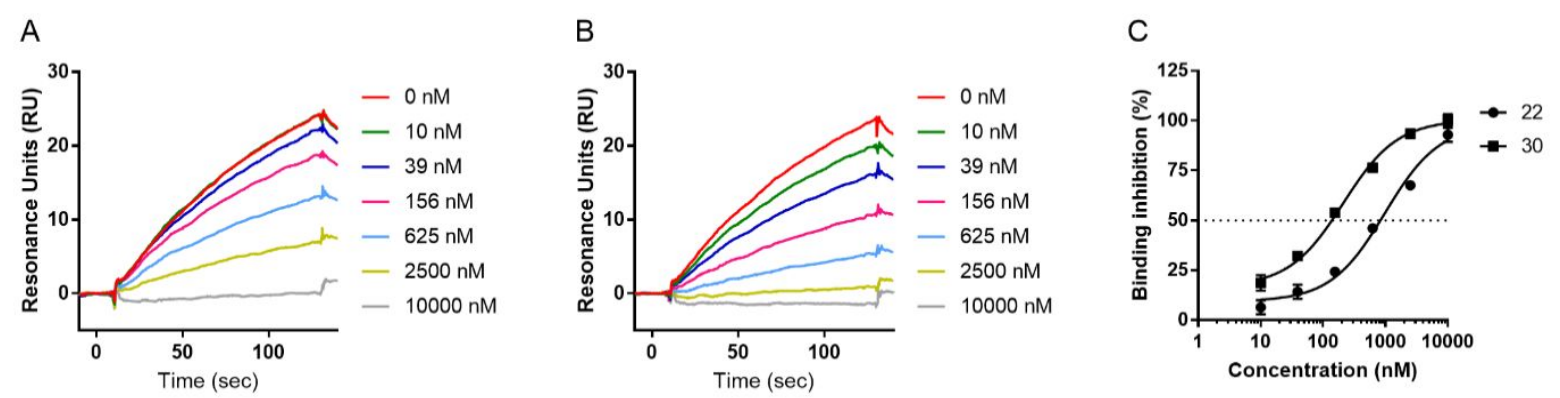

Figure 3. Inhibition of gp120-heparin binding by 22 and $\mathbf{3 0}$ as measured by SPR. Biotinylated heparin was captured on a Streptavidin Sensor Chip. Gp120 (10 nM) was mixed with a concentration range of compound 22 (A) or 30 (B). One representative sensorgram per compound out of three independent experiments is shown. Binding levels (RU) were converted into percentage inhibition relative to gp120 binding without compound. Mean (+SEM) and nonlinear fit of three independent experiments are shown (C). 


\section{Antiviral activity against EV71}

The newly synthesized compounds were also evaluated for their in vitro inhibitory effects against EV-A71 (Table 2). Tryptophan prototype 1 and pirodavir, a potent EV-A71 capsid binder, were used as reference compounds. ${ }^{56,57}$

First, we performed an antiviral activity assay against EV-A71 $\mathrm{BrCr}$, a laboratory-adapted strain, on rhabdomyosarcoma (RD) cells, which are known for their high susceptibility to EVA71 infection. ${ }^{58}$ For each analogue, the $\mathrm{EC}_{50}$ value was determined as the concentration of the drug protecting $50 \%$ of cells from EV-A71-induced cell death. Cell viability $\left(\mathrm{CC}_{50}\right)$ was also assessed on compound-treated, uninfected cells.

Interestingly, the SAR studies for EV-A71 revealed a similar profile to that observed for HIV. Compound 14, bearing a phenyl ring at $\mathrm{C} 2$ position, and compounds 15, 16, 17, 18 and 19, bearing phenyl rings substituents different than $\mathrm{COOH}\left(2-\mathrm{F}, 4-\mathrm{NO}_{2}, 4-\mathrm{Br}, 4-\mathrm{CF}_{3}, 4-\mathrm{OMe}\right.$, respectively), were inactive or more than 80 -fold less active than the prototype at sub-toxic concentrations. Similar to HIV, the unsubstituted tripodal and tetrapodal derivatives I and II, also proved inactive. However, the C2-arylated tryptophan derivatives 20, 22, 28-30, with phenyl rings substituted with one or two COOHs were as active or even more active than the prototype, indicating the importance of the carboxylic acids on the aromatic ring as a necessary requisite for antiviral activity. Notably, compound $\mathbf{3 0}$ resulted approximately eight-fold more potent than the prototype $\left(\mathrm{EC}_{50}: 0.04 \mu \mathrm{M} v s 0.3 \mu \mathrm{M}\right.$, respectively).

Interestingly, the antiviral potency of $\mathbf{2 0}\left(\mathrm{EC}_{50}: 0.99 \mu \mathrm{M}\right)$, bearing a $\mathrm{COOH}$ substituent at the meta-position of the phenyl ring, was 12-fold that of $21\left(\mathrm{EC}_{50}: 12.2 \mu \mathrm{M}\right)$, which carried the same substituent in the para position. These activity data suggest that the position of the $\mathrm{COOH}$ substituent on the phenyl ring is crucial for antiviral activity. Furthermore, similarly to HIV, no 
anti-EV-A71 activity was observed with compound 38, possessing the aromatic substituent at $\mathrm{N} 1$, while the closely related analog $29\left(\mathrm{EC}_{50}: 0.37 \mu \mathrm{M}\right)$, with the aromatic substituent at $\mathrm{C} 2$, was as active as the prototype $\left(\mathrm{EC}_{50}: 0.3 \mu \mathrm{M}\right)$. This result clearly demonstrates that the position of the aromatic substituent also plays an important role in the anti-EV-A71 and anti-HIV activity.

Several compounds (i.e., 22, 28, 29) showed selectivity indices higher $($ SI $>203,>336,161)$ than those found for the prototype (SI: 83) and comparable to those found for the reference compound, pirodavir (i.e., 28: SI >336; pirodavir: SI >333). This increase in the selectivity index is particularly due to a lower cytotoxic activity.

Notably, compound $\mathbf{3 0}$ is not toxic for the host cell. This compound turned out to have the highest selectivity index yet reported from the Trp class of compounds (SI $>2500$ for 30 vs SI: 83 for the prototype).

Table 2. Antiviral activity of dendrimers against the $\mathrm{BrCr}$ lab strain of EV-A71 virus in $\mathrm{RD}$ cells.

\begin{tabular}{|c|c|c|c|c|c|}
\hline Compound & $\begin{array}{c}\mathrm{EC}_{50} \mathrm{a}(\boldsymbol{\mu M}) \mathrm{EV}- \\
\mathrm{A} 71\end{array}$ & $\begin{array}{c}\mathbf{E C}_{90} \mathbf{b}(\boldsymbol{\mu M}) \\
\mathbf{E V}-\mathbf{A} 71\end{array}$ & $\mathrm{CC}_{50} \mathrm{c}(\boldsymbol{\mu M})$ & $\mathbf{S I}^{\mathbf{d}}$ & MWe $^{\mathrm{e}}$ (Da) \\
\hline 14 & $>100$ & ND & ND & ND & 1064.14 \\
\hline 15 & $>89.4$ & ND & ND & ND & 1118.12 \\
\hline 16 & $28.8 \pm 4.9$ & $58.2 \pm 16.3$ & $>83.4$ & ND & 1199.14 \\
\hline 17 & 65.2 & ND & ND & ND & 1300.83 \\
\hline 18 & $>78.9$ & ND & ND & ND & 1268.14 \\
\hline 19 & $>86.6$ & ND & ND & ND & 1154.22 \\
\hline 20 & $0.99 \pm 0.01$ & $1.35 \pm 0.1$ & $>83.6$ & $>73.4$ & 1196.17 \\
\hline
\end{tabular}




\begin{tabular}{|c|c|c|c|c|c|}
\hline $\mathbf{2 1}$ & $12.2 \pm 0.3$ & $\mathrm{ND}$ & $>33$ & $\mathrm{ND}$ & 1196.17 \\
\hline $\mathbf{2 2}$ & $0.35 \pm 0.03$ & $0.55 \pm 0.02$ & $>75.3$ & $>203$ & 1328.20 \\
\hline $\mathbf{2 8}$ & $0.19 \pm 0.01$ & $0.30 \pm 0.01$ & $>60.6$ & $>336$ & 1649.66 \\
\hline $\mathbf{2 9}$ & $0.37 \pm 0.08$ & $0.63 \pm 0.1$ & 56.4 & 161 & 1649.66 \\
\hline $\mathbf{3 0}$ & $0.04 \pm 0.01$ & $0.16 \pm 0.01$ & $>100$ & $>2500$ & 1825.69 \\
\hline $\mathbf{3 8}$ & $>19.5$ & $\mathrm{ND}$ & $\mathrm{ND}$ & $\mathrm{ND}$ & 1705.76 \\
\hline $\mathbf{I}$ & $>120$ & $\mathrm{ND}$ & $>120$ & $\mathrm{ND}$ & 835.86 \\
\hline $\mathbf{I I}$ & $>100$ & $\mathrm{ND}$ & $\mathrm{ND}$ & $\mathrm{ND}$ & 1169.24 \\
\hline $\mathbf{1}$ & $0.3 \pm 0.1$ & $0.5 \pm 0.06$ & 24.9 & 83 & 3573.84 \\
\hline Pirodavir & $0.3 \pm 0.1$ & $0.6 \pm 0.2$ & $>100$ & $>333$ & 369.47 \\
\hline
\end{tabular}

All values are in micromolar $(\mu \mathrm{M})$ and are a summary of multiple dose-response curves $(>2)$ in multiple independent $(>1)$ experiments.

ND: Not Determined

${ }^{\mathrm{a}} \mathrm{EC}_{50}$ : concentration of compound at which the virus-induced cytopathic effect is reduced by $50 \%$

${ }^{\mathrm{b}} \mathrm{EC}_{90}$ : concentration of compound at which the virus-induced cytopathic effect is reduced by $90 \%$

${ }^{\mathrm{c}} \mathrm{CC}_{50}$ : concentration of compound at which a $50 \%$ reduction in cell viability is observed

${ }^{\mathrm{d}} \mathrm{SI}$ : selectivity index $\left(\mathrm{CC}_{50} / \mathrm{EC}_{50}\right)$

e MW: Molecular weight of the molecules expressed as Da

The compounds with the best activity/toxicity profile, $\mathbf{2 2}, \mathbf{2 8}$ and $\mathbf{3 0}$, were evaluated in viruscell-based assays against a panel of clinical isolates representatives of the different (sub)genogroups of EV71 (B2, B5, C2 and C4) (Table 3). The prototype 1 was included as a reference. As previously observed for the prototype, the activity of compounds $\mathbf{2 2}, \mathbf{2 8}$ and $\mathbf{3 0}$ on the clinical isolates was improved with respect to those found for the $\mathrm{BrCr}$ lab strain (subgenogroup A). In particular, the greatest enhancement in antiviral activity was observed against sub-genogroup C4: 9-fold, 88-fold and 78-fold higher than the $\mathrm{BrCr}$ strain, respectively; whereas the lowest improvement was detected in the context of the infection with sub-genogroup B2 (only 2-fold, 4-fold and 6-fold improvement, respectively). It should be highlighted that the 
improvement was higher for the prototype $\mathbf{1}$ than for the new compounds 22, 28, 30 and among them for tetramers $\mathbf{2 8 ,} \mathbf{3 0}$ than for the trimer $\mathbf{2 2}$.

Table 3. Evaluation of the broad-spectrum antiviral effect of compounds 22, 28 and $\mathbf{3 0}$ against a representative panel of clinical EV71 isolates in RD cells.

\begin{tabular}{|c|c|c|c|c|c|}
\hline \multirow{2}{*}{$\begin{array}{c}\text { EV71 } \\
\text { Genogroup }\end{array}$} & Virus strain & $\mathbf{4}$ & EC $_{\mathbf{5 0}}(\mathbf{n M})^{\mathbf{a}}$ \\
\cline { 3 - 6 } & & $\mathbf{1}$ & $\mathbf{2 2}$ & $\mathbf{2 8}$ & $\mathbf{3 0}$ \\
\hline A & $\mathrm{BrCr}$ & $285 \pm 70$ & $353 \pm 31$ & $175 \pm 22$ & $109 \pm 34$ \\
\hline B2 & 11316 & $0.4 \pm 0.0$ & $179 \pm 11$ & $52 \pm 1$ & $19 \pm 0.6$ \\
\hline B5 & $\mathrm{TW} / 70902 / 08$ & $0.2 \pm 0.1$ & $81 \pm 13$ & $18 \pm 1$ & $5.9 \pm 0.7$ \\
\hline C2 & $\mathrm{H} 08300461 \# 812$ & $1.1 \pm 0.3$ & $57 \pm 0.2$ & $7.3 \pm 0.8$ & $2.6 \pm 0.6$ \\
\hline C4 & $\mathrm{TW} / 1956 / 05$ & $0.2 \pm 0.2$ & $38 \pm 3$ & $2.0 \pm 0.2$ & $1.4 \pm 0.7$ \\
\hline
\end{tabular}

${ }^{\mathrm{a} A l l}$ values are in nanomolar $(\mathrm{nM})$ and are obtained in multiple $(>2)$ independent $(>1)$ experiments.

Following microscopic quality control, at least at one concentration of compound, no virusinduced cell death was observed and the compound did not cause an adverse effect on the host cell or monolayer morphology.

\section{Mode of action in the context of EV-A71 infection}

\subsection{Time-of-drug-addition (TOA) experiment (EV-A71)}

To determine whether the reduced size of the newly synthetized analogues affects their mechanism of inhibition of EV-A71 replication, we performed a TOA assay with a representative member, compound $\mathbf{2 2}$. In order to confirm the activity of compound $\mathbf{2 2}$ as an early stage inhibitor, we included the capsid binder pirodavir as a control (Figure 4). ${ }^{56,59}$ 


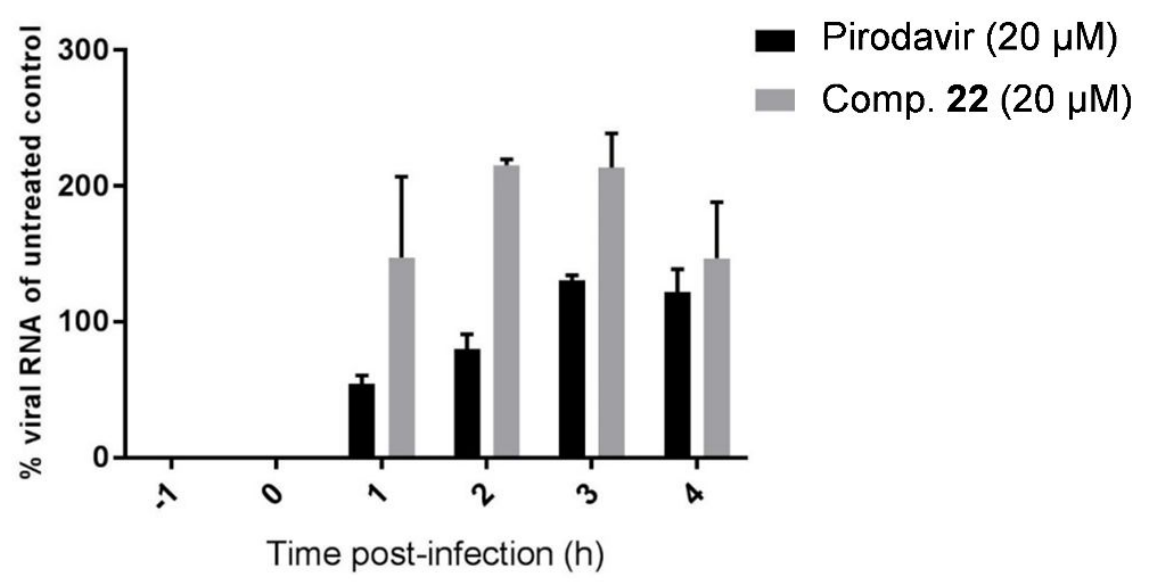

Figure 4. Time-of-drug-addition for compound 22. RD cells were treated with the compounds at selected times before, during or after infection with EV-A71. 8h post-infection, cells were harvested and intracellular viral RNA was isolated and quantified by means of RT-qPCR.

Similar to pirodavir, only the addition of compound 22, prior to or at the moment of infection resulted in a complete inhibition of viral replication whereas the addition after infection was associated with a complete loss of protection. This experiment clearly shows that $\mathbf{2 2}$, as previously observed for prototype $1,{ }^{28}$ inhibits early step(s) of the replicative cycle of EV-A71.

\subsection{Cross-resistance studies}

Two of the most active anti-EV-A71 compounds $\mathbf{2 2}$ and 30, were also evaluated for their inhibitory activity against single mutant EV-A71 strains VP1_S184T and VP1_P246S and the double mutant VP1_S184T_P246S that confer resistance to the prototype 1 (Table 4). Interestingly, $\mathbf{2 2}$ and $\mathbf{3 0}$ retain some antiviral activity $\left(\mathrm{EC}_{50}: 1.96-2.35 \mu \mathrm{M}\right)$ against these mutant virus strains, although this activity is at least 5.6 to 6.7 -fold lower than against the wild-type virus. These data point to the fact that the resistant viruses emerging under the selective pressure of $\mathbf{1}$ are also cross-resistant to $\mathbf{2 2}$ and $\mathbf{3 0}$ suggesting that these compounds are likely to share an 
overall similar mechanism of antiviral activity (and resistance) and a binding site with the parent prototype 1, namely the five-fold axis of the capsid. However, it cannot be excluded that $\mathbf{2 2}$ and 30, which show some residual activity against the mutant viral strains and are the most active Trp derivatives ever reported, may give rise to additional interactions with amino acids at the five-fold axis, thus accounting for the residual activity against EV-A71 mutant viruses.

Table 4. Susceptibility of reverse-engineered EV-A71 variants to prototype $\mathbf{1}$ and compounds $\mathbf{2 2}$ and $\mathbf{3 0}$

\begin{tabular}{|cccc|}
\hline Virus & $\begin{array}{c}\mathbf{1} \\
\mathbf{E C}_{\mathbf{5 0}}^{\mathbf{a}}(\boldsymbol{\mu M})\end{array}$ & $\begin{array}{c}\mathbf{2 2} \\
\mathbf{E C}_{\mathbf{5 0}}{ }^{\mathbf{a}}(\boldsymbol{\mu M})\end{array}$ & $\begin{array}{c}\mathbf{3 0} \\
\mathbf{E C}_{\mathbf{5 0}}^{\mathbf{a}}(\boldsymbol{\mu M})\end{array}$ \\
\hline EV-A71 BrCr & $0.28 \pm 0.01$ & $0.35 \pm 0.03$ & $0.1 \pm 0.03$ \\
VP1_S184T & $1.99 \pm 0.10(7.1)$ & $2.35 \pm 0.60(6.7)$ & $0.9 \pm 0.05(8.5)$ \\
VP1_P246S & $4.71 \pm 0.18(16.8)$ & $1.96 \pm 0.04(5.6)$ & $0.2 \pm 0.09(1.8)$ \\
VP1_S184T_P246S & $8.93 \pm 0.53(31.9)$ & $2.18 \pm 0.08(6.2)$ & $0.3 \pm 0.04(3.1)$ \\
\hline
\end{tabular}

Averages and SD (standard deviation) were calculated from data obtained from three independent antiviral assays; (xxxxxx), fold resistance.

\subsection{Cryo-electron microscopy studies}

To identify the binding sites of $\mathbf{2 2}$ and 30, purified capsids of EV-A71 strain 11319 were incubated with each drug and vitrified for cryo-electron microscopy (cryo-EM) reconstructions. Refinement with icosahedral symmetry averaging imposed generated $2.98 \AA$ and $2.87 \AA$ resolution maps for $\mathbf{2 2}$ and $\mathbf{3 0}$ complexes respectively (Figure 5 and S1 Table). Sharpened maps of the two EV-A71-22 and 30 complexes were almost identical with the map of the EV-A71 strain $11319^{41}$ (Figure 5A) and no extra densities on the 5-fold vertexes, where the drugs are predicted to bind, were found. However, unsharpened maps of both virus-drug complexes revealed thin extra densities covering the 5-fold axis (Fig 5B and C). This finding indicates that 
A
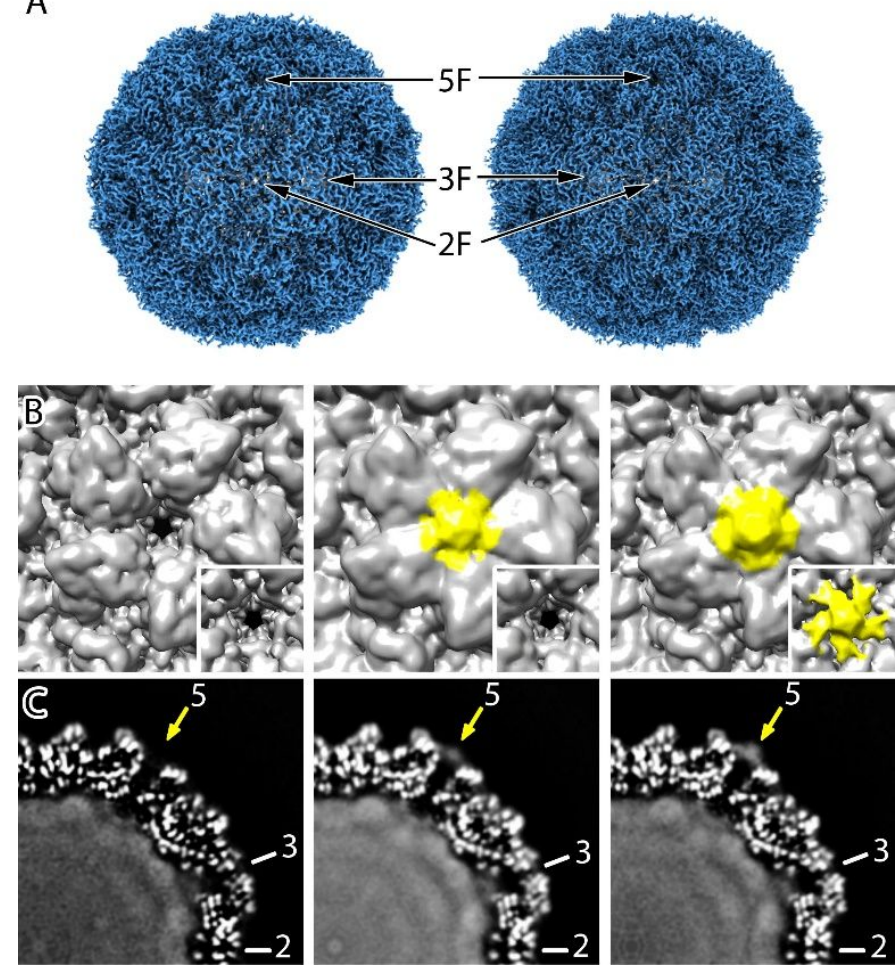

Figure 5. Cryo-EM 3D maps identified the MADAL compounds on the capsid 5-fold axis. (A) Surface rendering of the sharpened 3D maps for EV-A71 incubated with 22 (left) and $\mathbf{3 0}$ (right) showed canonical features of the capsid. Icosahedral symmetry axes were marked with arrows. (B) Comparison of the unsharpened maps (gray) of $\mathbf{2 2}$ and $\mathbf{3 0}$ complexes with EV-A71 showed extra densities (yellow) on the 5 -fold axis. The surface rendered at $1 \sigma$ and $1.9 \sigma$ (insets) for EV-A71 (left), 22 (middle) and 30 (right). (C) Central sections of the three cryo-EM maps showed extra densities on the 5-fold-vertex covering the hole at the symmetry axis. Icosahedral symmetry axes were marked.

Compound 30 showed a stronger drug density compared to 22 (Fig 5B inlets), suggesting higher affinity of the former with respect to the latter since both compounds were incubated at the same concentration. The significant density for $\mathbf{3 0}$ appeared to cover the 5-fold axis like a lid and did not penetrate into the pore (Figure 5C) although it cannot be excluded the possibility that 
a part of the drug might have lodged into it but its density was averaged out. The density intensity of the bound molecule in an icosahedral map is directly related to the occupancy and/or structural heterogeneity (multiple conformations) of the molecules. As shown in our previous study using prototype $\mathbf{1}$, multiple conformations of the bound drug would decrease its density intensity. ${ }^{41}$ This may be a common observation for drugs bound at the 5 -fold axis.

Atomic models of the viral capsids were refined using the two complex maps (Figure 6A). Densities attributable to residue backbones and side chains were recognizable in the maps (Figure 6B). The capsid proteins VP1-4 did not show any significant conformational differences or rigid body movements from the atomic model of EV-A71 (RMSD $0.719 \AA$ and $0.838 \AA$ for 22 and 30, respectively). Cryo-EM densities corresponding to the pocket factor were also observed in both maps (Figure 6B and data not shown). The capsid interactions with RNA genome also did not change (data not shown). Thus, binding of $\mathbf{2 2}$ and $\mathbf{3 0}$ on EV-A71 did not induce any significant conformational changes on the capsids, including pocket factor release.

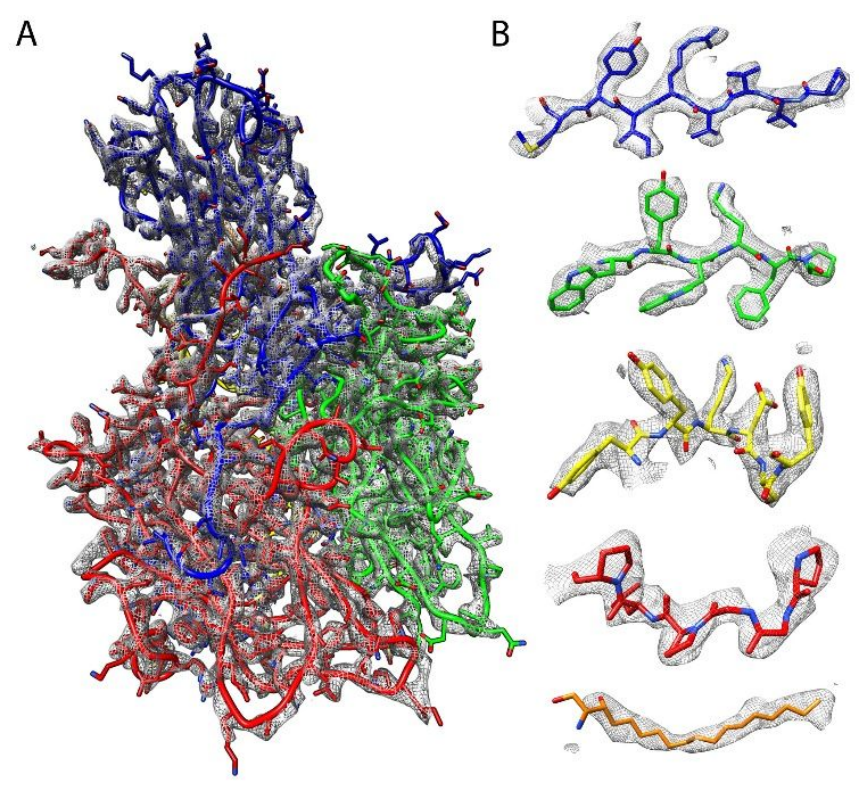

Figure 6. Atomic model built into the cryo-EM map. (A) The atomic models for EV-A71 VP1 (blue), VP2 (green), VP3 (red), VP4 (yellow), and the pocket factor (orange) were built into the cryo-EM map of the virus-30 complex (gray mesh). (B) Representative residues of each VP and 

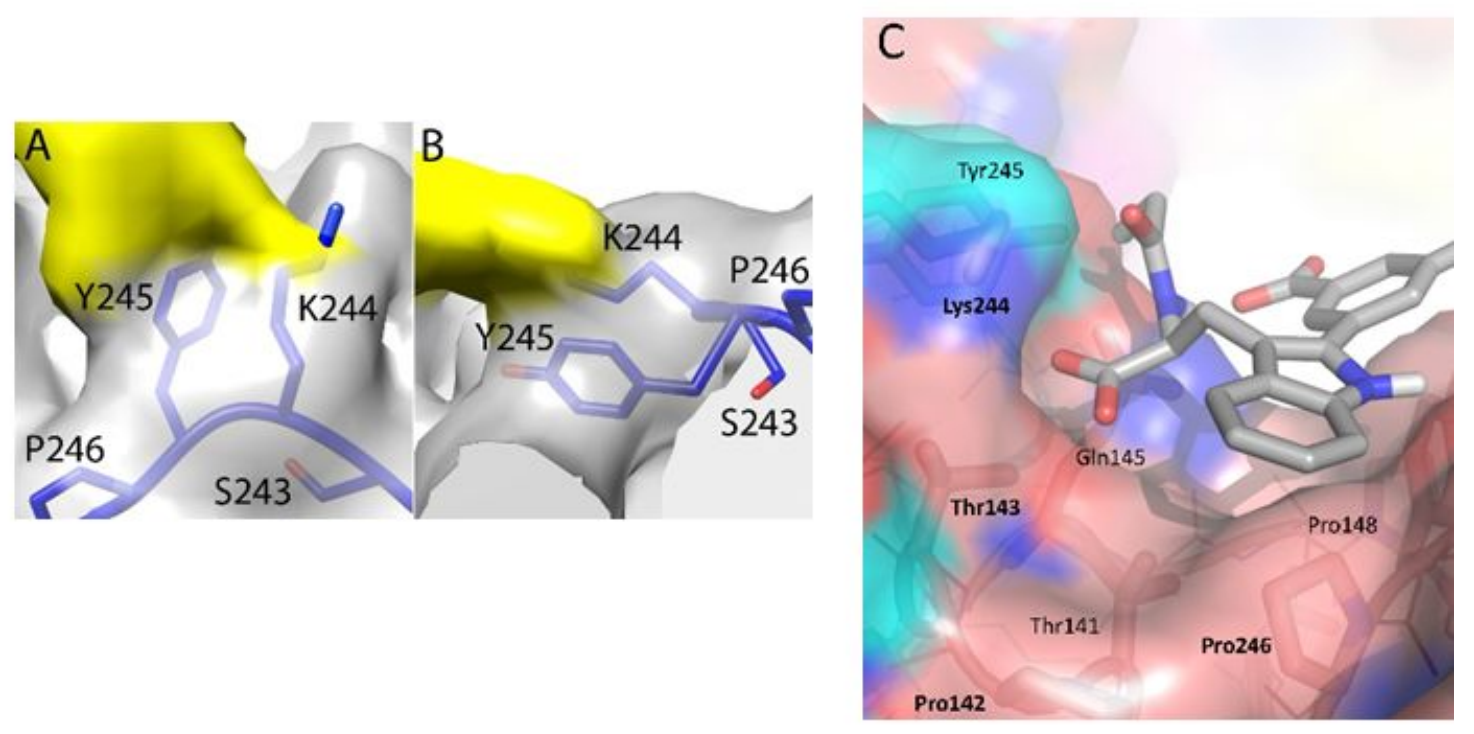

the pocket-factor are shown within the corresponding cryo-EM density envelopes to illustrate the quality of the 3D map.

The superimposition of the atomic model in the unsharpened maps showed that the extra densities are strongly connected to Lys244 (K244) and Tyr245 (Y245) residues of VP1 (Figure 7).

Figure 7. The drug densities are connected to two VP1 residues. (A) The icosahedrally averaged drug density (yellow, 30) was connected mostly with Lys244 and Tyr245 on the VP1 surface (grey). The atomic model of VP1 is depicted as a blue ribbon and the side-chains are shown as sticks. The surface is rendered at $1.9 \sigma$. Neighboring residues are also labeled. (B) Sideview of the interaction site shows the thin drug density connected to the two VP1 residues. (C) Binding pose proposed by the automated docking program for the substituted Trp residue in $\mathbf{3 0}$ at the interface between chains E (cyan) and Q (pink).

Further atomistic detail about the complex formed between $\mathbf{3 0}$ and the VP1 pentamer was gained by performing automated docking calculations with the decorated Trp moiety attached to each of its four 'legs' (Scheme 2). In the best-scored and most populated pose (Figure 7C and Supporting Information, Figure 1) the Trp is lodged at the interface between two VP1 monomers 
in a cavity lined by the adjoined ${ }^{141} \mathrm{TPTGQVVP}{ }^{148}$ and ${ }^{242} \mathrm{QSKYP}^{246}$ stretches from one subunit and the ${ }^{242} \mathrm{QSKYP}{ }^{246}$ stretch from a neighboring subunit. In this orientation, (i) the indole ring of Trp and the phenyl ring of the isophthalate moiety stack on Pro246 and Tyr245, respectively, the latter in an edge-to-face arrangement; (ii) the Trp carboxylate establishes a hydrogen bond with the side-chain hydroxyl of Thr143 and a strong ionic interaction with the charged amino group of Lys244 from a neighboring subunit; (iii) the carboxamide nitrogen of Gln145 hydrogen bonds to one of the isophthalate carboxylates; and (iv) the other isophthalate carboxylate points to the positively charged Lys244 that is vicinal to the Tyr243 on which the phenyl ring stacks. Importantly, this pose is compatible not only with the electron density (Figure 7) but also with the fact that the ethylene linker connecting this decorated Trp to the pentaerythritol core points towards the central pore. Thus, one can figure out that one of the tetrapod's legs fits snugly into the proposed intersubunit cavity whereas the other three, which cannot bind in a similar fashion simultaneously, establish less specific van der Waals and electrostatic interactions with the residues lining the pore. Since all five VP1 subunits are identical, as are all of the dendrimer's protrusions, the overall binding mode is an average of all five combinations that is also in consonance with the average experimental electron density (Figure 8 and Supporting Information, Figure 2). Thus, it can be assumed that binding of $\mathbf{3 0}$ within this region prevents the interaction of the virus with its cellular (co-)receptors P-selectin glycoprotein ligand-1 (PSGL-1) and heparan sulfate thereby blocking attachment of EV-A71 to the host cells. 
A

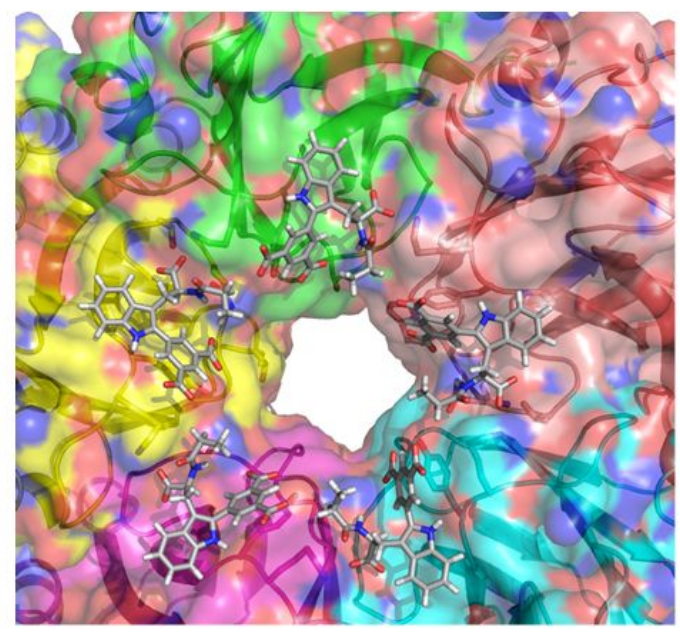

B

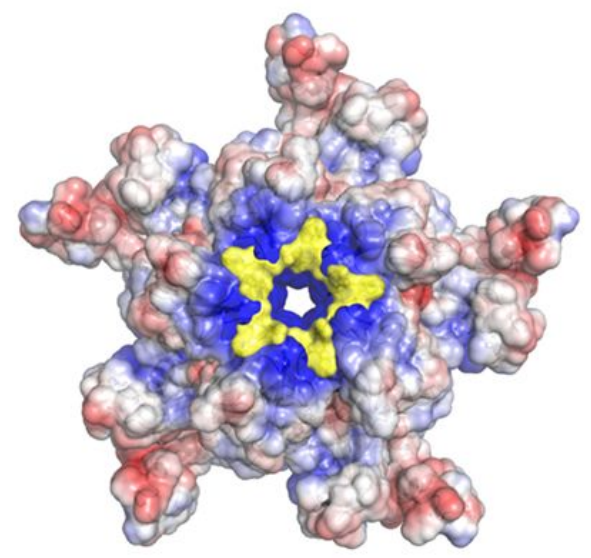

Figure 8. Proposed binding mode of the decorated Trp moiety of 30 around the 5-fold axis of the EV-A71 capsid. (A) A semitransparent surface envelops the five VP1 chains making up the pore. C atoms in chains A, E, I, M, and Q are colored in green, cyan, magenta, yellow and pink, respectively. Note that the ethylene linker points towards the central pore. (B) Solventaccessible surface of the VP1 pentamer color-coded according to the molecular electrostatic potential calculated with APBS (red, $-3.0 \mathrm{kT} / \mathrm{e}$; blue, $+3.0 \mathrm{kT} / \mathrm{e}$ ). The yellow surface filling the subunit interfaces corresponds to the van der Waals surface of the five docked fragments shown in $(\mathbf{A})$.

\section{CONCLUSIONS}

Using a scaffold simplification strategy, a novel generation of dual HIV and enterovirus-A71 entry inhibitors has been synthesized. These compounds contain three or four tryptophan (Trp) residues bearing at the $\mathrm{C} 2$ position of their indole side-chains a substituted phenyl ring. A highly efficient and scalable method has been developed for the synthesis of these compounds.

SAR studies showed that the presence of one or two carboxylates on the C2 extra phenyl rings is critical for anti-HIV and EV-A71 activity. The most potent, 22 and 30, showed enhanced activity ( $\sim 10$ and 100-fold) against HIV-1 compared to the former dendrimer prototype discovered in our group. Notably, $\mathbf{3 0}$ is the only congener within this series that showed potent anti-HIV-2 activity. Time-of-drug-addition (TOA) experiments, followed by SPR studies 
revealed that $\mathbf{2 2}$ and $\mathbf{3 0}$ act at early stages of the viral replication cycle of HIV by binding to the viral envelope glycoprotein gp120. Moreover, they also proved to be potent inhibitors of EV71, inhibiting not only the laboratory $\mathrm{BrCr}$ strain of EV-A71 but also clinical isolates of enteroviruses A, B and C. By means of cross-resistance studies, followed by cryo-EM, we mapped the binding region of $\mathbf{2 2}$ and $\mathbf{3 0}$ to the 5-fold axis of the EV-A71 capsid. Further details about the binding mode were provided by computer-assisted modeling studies that included docking of the common isophthaloyl-decorated Trp residue and molecular dynamics simulations. All in all, the structures presented herein provide a very consistent picture about the mode of binding of these compounds to the VP1 pentamer making up the pore region.

Compounds 22 and $\mathbf{3 0}$ are non-toxic for different types of host cells and show the highest selectivity indices yet reported for the Trp class of compounds. Moreover, these compounds specifically inhibit replication of HIV (HIV-1 and HIV-2) and EV71 (laboratory-adapted strain $\mathrm{BrCr}$ and different EV71 clinical isolates from different genogroups and geographic origins).

Taken together, these results show that this new type of Trp derivatives are important leads as dual HIV and EV71 entry inhibitors. The higher potency, lower toxicity, half-size, easy of chemical synthesis and greater opportunities for chemical optimization make them more useful than the former Trp dendrimers discovered in our group for future medicinal chemistry studies.

\section{EXPERIMENTAL SECTION}

Synthesis. General Chemical Procedures. Commercial reagents and solvents were used as received from the suppliers without further purification unless otherwise stated. The solvents used in some reactions were dried prior to use. DMF dry was commercially available (Aldrich). 
A microwave reactor Emrys ${ }^{\mathrm{TM}}$ Synthesizer (Biotage $\mathrm{AB}$ ) was used for the reactions which needed microwave irradiation.

Analytical thin-layer chromatography (TLC) was performed on aluminum plates precoated with silica gel $60\left(\mathrm{~F}_{254}, 0.20 \mathrm{~mm}\right)$. Products were visualized using an ultraviolet lamp (254 $\mathrm{nm}$ and $365 \mathrm{~nm}$ ) or by heating after treatment with a 5\% solution of phosphomolybdic acid (PMA) or vanillin in ethanol.

The compounds were purified by: a) high performance flash chromatography (HPFC) with a system "Isolera One" (Biotage) in reverse phase using water/acetonitrile (100:0 to 0:100) as eluent, b) flash column chromatography on silica gel (60 Merck 230-400 mesh), c) preparative centrifugal circular thin layer chromatography (CCTLC) on a chromatotron ${ }^{\circledR}$ (Kiesegel 60 PF254 gipshaltig, Merck) layer thickness $1 \mathrm{~mm}$, flow rate $2-4 \mathrm{~mL} / \mathrm{min}$.

The purity of final compounds was at least $95 \%$ as determined by microanalyses with a Heraeus CHN-O-RAPID instrument. Analyses indicated by the symbols of the elements or functions were within $\pm 0.4 \%$ of the theoric value.

For HPLC analysis an Agilent Technologies 1120 Compact LC with a reverse phase column ACE 5 C18-300 (4.6 mm $\times 150 \mathrm{~mm}, 3.5 \mu \mathrm{m})$ equipped with a PDA (Photo Diode Array) detector was used. Acetonitrile was used as mobile phase A, and water $0.05 \%$ of TFA was used as mobile phase $\mathrm{B}$ with at a flow rate of $1 \mathrm{~mL} \cdot \mathrm{min}^{-1}$. All retention times are quoted in minutes and the gradients are specified for each compound in the experimental data.

For high resolution mass spectrometry (HRMS) was used an Agilent 6520 Accurate Mass QTOF (quadrupole time of flight) coupled with LC/MS using an electrospray interface (ESI) working in the positive-ion $\left(\mathrm{ESI}^{+}\right)$and negative-ion $\left(\mathrm{ESI}^{-}\right)$mode. 
NMR spectra $\left({ }^{1} \mathrm{H},{ }^{13} \mathrm{C}\right.$ NMR) were recorded on a Varian UNIT INOVA-300 (300 MHz), Bruker AVANCE 300 (300 and 75 MHz), Varian INOVA-400 (400 and $100 \mathrm{MHz}$ ), Varian MERCURY-400 (400 and $100 \mathrm{MHz}$ ) and Varian-500 (500 and $125 \mathrm{MHz}$ ) spectrometers, using $\left(\mathrm{CD}_{3}\right)_{2} \mathrm{SO}$ and $\mathrm{CDCl}_{3}$ as solvents. Chemical shift $(\delta)$ values are reported in parts per million (ppm) relative to tetramethylsilane (TMS) in ${ }^{1} \mathrm{H}$ and $\mathrm{CDCl}_{3}(\delta=77.0)$ in ${ }^{13} \mathrm{C} \mathrm{NMR}$. Coupling constant $(J$ values) are reported in hertz $(\mathrm{Hz})$ and multiplicities of signals are indicated by the following symbol: s (singlet), d (doublet), t (triplet), q (quadruplet), m (multiplet) and bs (broad singlet). Some two-dimensional spectra (COSY, HSQC and HMBC) were performed to identify the structure.

Final compounds were lyophilized using a Telstar 6-80 system.

\section{General coupling procedure for the synthesis of the trimer 4 and tetramer 24 . To a} solution containing triacid $\mathbf{3}^{47}$ or $\mathbf{2 3}^{48,49}$ ( $1 \mathrm{mmol}$ ), HATU (1.2 eq each carboxylic acid group) and $\mathrm{H}-\mathrm{TrpOMe} \cdot \mathrm{HCl}(1.2$ eq each carboxylic acid group) in DMF (20 mL), DIPEA (3.4 eq each carboxylic acid group) were added. The reaction mixture was stirred at $30{ }^{\circ} \mathrm{C}$ for $48 \mathrm{~h}$ and then evaporated to dryness. The residue was dissolved in dichloromethane $(20 \mathrm{~mL})$ and washed successively with aqueous solutions of citric acid (10\%) $(3 \times 20 \mathrm{~mL})$, saturated $\mathrm{NaHCO}_{3}(3 \times 20$ $\mathrm{mL})$, and brine $(3 \times 20 \mathrm{~mL})$. The organic phase was dried over anhydrous $\mathrm{Na}_{2} \mathrm{SO}_{4}$, filtered and evaporated to dryness. The residue was purified on a Biotage HPFC (High Performance Flash Chromatography) purification system on reverse phase using water/acetonitrile (100:0 to 0:100) as eluent to give the corresponding compound.

Trimer 4. Following the general coupling procedure, compound $\mathbf{3}^{47}$ (500 $\mathrm{mg}, 1.80 \mathrm{mmol}$ ), HATU (2.47 g, $6.49 \mathrm{mmol}), \mathrm{H}-\mathrm{TrpOMe} \cdot \mathrm{HCl}(1.65 \mathrm{mg}, 6.49 \mathrm{mmol}$ ), DIPEA (3.14 mL, 18.03 
mmol) afforded $1.53 \mathrm{~g}(97 \%)$ of 4 as an amorphous solid of cream color. ${ }^{1} \mathrm{H}$ NMR (400 MHz, $\left.\mathrm{CDCl}_{3}\right) \delta: 8.59\left(\mathrm{~d}, J=6.3 \mathrm{~Hz}, 3 \mathrm{H}, \mathrm{NH}-1^{\mathrm{i} T r p}\right), 7.43(\mathrm{~d}, J=7.9 \mathrm{~Hz}, 3 \mathrm{H}, \mathrm{Ar}), 7.27-7.24(\mathrm{~m}, 3 \mathrm{H}$, Ar), 7.11 (ddt, $J=8.0,7.0,0.9 \mathrm{~Hz}, 3 \mathrm{H}, \mathrm{Ar}), 7.03$ (ddt, $J=7.9,7.0,1.0 \mathrm{~Hz}, 3 \mathrm{H}, \mathrm{Ar}), 6.87$ (d, $J=$ $2.3 \mathrm{~Hz}, 3 \mathrm{H}, \mathrm{Ar}), 6.40$ (t, $J=8.1 \mathrm{~Hz}, 3 \mathrm{H}, \mathrm{NHCO}$ ), 4.87-4.80 (m, 3H, $\alpha$-CHTrp), 3.27 (dd, $J=$ 14.9, $5.1 \mathrm{~Hz}, 3 \mathrm{H}, \beta$-CH2Trp), 3.15 (dd, $\left.J=14.9,6.8 \mathrm{~Hz}, 3 \mathrm{H}, \beta-\mathrm{CH}_{2} \mathrm{Trp}\right), 1.92-1.70$ (m, $12 \mathrm{H}$, $\mathrm{CH}_{2}$ ). HPLC [gradient: A:B, 10-100\% of A in $10 \mathrm{~min}$ ]: $6.865 \mathrm{~min}$. HRMS $\left(\mathrm{ESI}^{+}\right) \mathrm{m} / \mathrm{z}$ : Cald for $\mathrm{C}_{46} \mathrm{H}_{51} \mathrm{~N}_{7} \mathrm{O}_{11}$ 877.3177; found 877.3163.

Tetramer 24. Following the general coupling procedure, compound $\mathbf{2 3}^{48,49}$ (200 $\mathrm{mg}, 0.47$ mmol), HATU (0.85 g, $2.26 \mathrm{mmol}), \mathrm{H}-\mathrm{TrpOMe} \cdot \mathrm{HCl}(0.55 \mathrm{mg}, 2.26 \mathrm{mmol}$,), DIPEA (0.82 mL, $4.71 \mathrm{mmol})$ afforded $470 \mathrm{mg}(82 \%)$ of $\mathbf{2 4}$ as an amorphous solid of cream color. ${ }^{1} \mathrm{H}$ NMR (300 $\left.\mathrm{MHz}, \mathrm{CDCl}_{3}\right) \delta: 9.29$ (d, $\left.J=2.4 \mathrm{~Hz}, 4 \mathrm{H}, \mathrm{NH}-1^{\mathrm{i}} \mathrm{Trp}\right), 7.48$ (dd, $\left.J=6.9,1.9 \mathrm{~Hz}, 4 \mathrm{H}, \mathrm{Ar}\right), 7.25-$ 7.19 (m, 4H, Ar), 7.13-7.01 (m, 8H, Ar), 6.96 (d, $J=2.3 \mathrm{~Hz}, 4 \mathrm{H}, \mathrm{Ar}), 6.79$ (d, $J=7.8 \mathrm{~Hz}, 4 \mathrm{H}$, NHCO), 5.03-4.95 (m, 4H, $\alpha$-CHTrp), $3.71\left(\mathrm{~s}, 12 \mathrm{H}, \mathrm{OCH}_{3}\right), 3.36$ (d, $\left.J=5.0 \mathrm{~Hz}, 8 \mathrm{H}, \beta-\mathrm{CH}_{2} \mathrm{Trp}\right)$, 3.26-3.17 (m, 4H, $\left.\mathrm{OCH}_{2}\right), 3.13-3.03\left(\mathrm{~m}, 4 \mathrm{H}, \mathrm{OCH}_{2}\right), 2.86\left(\mathrm{~d}, J=9.2 \mathrm{~Hz}, 4 \mathrm{H}, \mathrm{OCH}_{2}\right), 2.47(\mathrm{~d}, J$ $\left.=9.2 \mathrm{~Hz}, 4 \mathrm{H}, \mathrm{OCH}_{2}\right), 2.32-2.16\left(\mathrm{~m}, 8 \mathrm{H}, \mathrm{CH}_{2}\right) . \mathrm{HPLC}$ [gradient: A:B, $10-100 \%$ of A in $10 \mathrm{~min}$ ]: 5.483 min. HRMS (ESI ${ }^{+}$) m/z: Cald for $\mathrm{C}_{65} \mathrm{H}_{76} \mathrm{~N}_{8} \mathrm{O}_{16}$ 1224.4857; found 1224.4836.

\section{General procedure for the synthesis of the C2 arylated trimers 5-13 and tetramers}

25-27. The corresponding starting compound $\mathbf{4}$ or $\mathbf{2 4}$ ( $1 \mathrm{mmol})$, aryl iodide ( 2 eq for each Trp), $\mathrm{AgBF}_{4}\left(2\right.$ eq for each Trp), TFA ( 1 eq for each Trp) and $\mathrm{Pd}(\mathrm{OAc})_{2}(5 \%$ mol $)$ were placed in a microwave reactor vessel in dry DMF $(2 \mathrm{~mL})$. The mixture was heated under microwave irradiation $(250 \mathrm{~W})$ at $120{ }^{\circ} \mathrm{C}$ for $30 \mathrm{~min}$. The resulting suspension was filtered through Whatman ${ }^{\circledR}$ filter paper 42 , and the solvent was removed under vacuum. The residue was dissolved in ethyl acetate $(20 \mathrm{~mL})$ and washed successively with saturated $\mathrm{NaHCO}_{3}(3 \times 20 \mathrm{~mL})$, 
and brine $(3 \times 20 \mathrm{~mL})$. The organic phase was dried over anhydrous $\mathrm{Na}_{2} \mathrm{SO}_{4}$, filtered and evaporated to dryness. The residue was purified by CCTLC using dichloromethane/methanol (20:1) as eluent.

Trimer 5. Following the general procedure, compound 4 (50 $\mathrm{mg}, 0.057 \mathrm{mmol})$, iodobenzene (38.3 $\mu \mathrm{L}, 0.342 \mathrm{mmol}), \mathrm{Pd}(\mathrm{OAc})_{2}\left(0.6 \mathrm{mg}, 0.003 \mathrm{mmol}\right.$ ), $\mathrm{AgBF}_{4}(66.5 \mathrm{mg}, 0.342 \mathrm{mmol})$ and TFA $(13.1 \mu \mathrm{L}, 0.171 \mathrm{mmol})$ afforded $35.9 \mathrm{mg}(56.9 \%)$ of $\mathbf{5}$ as an amorphous solid of cream color. ${ }^{1} \mathrm{H}$ NMR (500 MHz, $\left.\mathrm{CDCl}_{3}\right) \delta: 8.45$ (bs, 3H, NH-1 $\left.{ }^{\mathrm{i}} \mathrm{Trp}\right), 7.53-7.48$ (m, 9H, Ar), 7.41 (t, $J$ $=7.6 \mathrm{~Hz}, 6 \mathrm{H}, \mathrm{Ar}), 7.35-7.30(\mathrm{~m}, 3 \mathrm{H}, \mathrm{Ar}), 7.25(\mathrm{~d}, J=2.9 \mathrm{~Hz}, 3 \mathrm{H}, \mathrm{Ar}), 7.16-7.11(\mathrm{~m}, 3 \mathrm{H}, \mathrm{Ar})$, 7.10-7.05 (m, 3H, Ar), 5.81 (d, J=7.9 Hz, 3H, NHCO), 4.79-4.74 (m, 3H, $\alpha$-CHTrp), 3.51 (dd, $\left.J=14.7,5.7 \mathrm{~Hz}, 3 \mathrm{H}, \beta-\mathrm{CH}_{2} \mathrm{Trp}\right), 3.44\left(\mathrm{dd}, J=14.8,6.0 \mathrm{~Hz}, 3 \mathrm{H}, \beta-\mathrm{CH}_{2} \mathrm{Trp}\right), 3.37$ (s, 9H, $\mathrm{OCH}_{3}$ ), 1.74-1.62 (m, 6H, $\left.\mathrm{CH}_{2}\right), 1.57-1.49\left(\mathrm{~m}, 3 \mathrm{H}, \mathrm{CH}_{2}\right), 1.43-1.33\left(\mathrm{~m}, 3 \mathrm{H}, \mathrm{CH}_{2}\right)$. HPLC [gradient: A:B, $10-100 \%$ of $A$ in $10 \mathrm{~min}$ ]: $4.999 \mathrm{~min}$. HRMS $\left(\mathrm{ESI}^{+}\right) \mathrm{m} / \mathrm{z}$ : Cald for $\mathrm{C}_{64} \mathrm{H}_{63} \mathrm{~N}_{7} \mathrm{O}_{11} 1105.4116$; found 1105.4102 .

Trimer 6. Following the general procedure, compound 4 (100 $\mathrm{mg}, 0.114 \mathrm{mmol})$, 2fluoroiodobenzene (79 $\mu \mathrm{L}, 0.683 \mathrm{mmol}), \mathrm{Pd}(\mathrm{OAc})_{2}\left(1.3 \mathrm{mg}, 0.006 \mathrm{mmol}\right.$ ), $\mathrm{AgBF}_{4}(132.97 \mathrm{mg}$, $0.683 \mathrm{mmol})$ and TFA $(26 \mu \mathrm{L}, 0.342 \mathrm{mmol})$ afforded $38.2 \mathrm{mg}(29 \%)$ of $\mathbf{6}$ as an amorphous solid of cream color. ${ }^{1} \mathrm{H}$ NMR (300 MHz, $\left.\mathrm{CDCl}_{3}\right) \delta: 8.45$ (bs, 3H, NH-1 $\left.{ }^{\mathrm{i}} \mathrm{Trp}\right), 7.58-7.47$ (m, 6H, Ar), 7.42-7.34 (m, 3H, Ar), 7.30-7.06 (m, 15H, Ar), 5.87 (d, $J=7.9$ Hz, 3H, NHCO), 4.84-4.75 (m, $3 \mathrm{H}, \alpha$-CHTrp), $3.51-3.31\left(\mathrm{~m}, 15 \mathrm{H}, \beta-\mathrm{CH}_{2} \operatorname{Trp}\right.$ and $\left.\mathrm{OCH}_{3}\right), 1.82-1.60\left(\mathrm{~m}, 9 \mathrm{H}, \mathrm{CH}_{2}\right), 1.56-1.42$ (m, $3 \mathrm{H}, \mathrm{CH}_{2}$ ). HPLC [gradient: A:B, 10-100\% of A in $10 \mathrm{~min}$ ]: $7.406 \mathrm{~min}$. HRMS (ESI ${ }^{+}$) m/z: Cald for $\mathrm{C}_{64} \mathrm{H}_{60} \mathrm{~F}_{3} \mathrm{~N}_{7} \mathrm{O}_{11} 1159.3833$; found 1159.3829.

Trimer 7. Following the general procedure, compound 4 (50 mg, $0.057 \mathrm{mmol})$, 1-iodo-4nitrobenzene ( $85.2 \mathrm{mg}, 0.342 \mathrm{mmol}), \mathrm{Pd}(\mathrm{OAc})_{2}(0.6 \mathrm{mg}, 0.003 \mathrm{mmol}), \mathrm{AgBF}_{4}(66.6 \mathrm{mg}, 0.342$ 
mmol) and TFA (13 $\mu \mathrm{L}, 0.171 \mathrm{mmol})$ afforded $33.4 \mathrm{mg}(47 \%)$ of 7 as an amorphous solid of cream color. ${ }^{1} \mathrm{H}$ NMR (300 MHz, DMSO) $\delta$ : 11.51 (bs, 3H, NH-1 $\left.{ }^{\mathrm{T}} \mathrm{Trp}\right), 8.48$ (d, J=7.7 Hz, 3H, NHCO), 8.37-8.26 (m, 6H, Ar), 7.96-7.83 (m, 6H, Ar), 7.59 (d, J=7.9 Hz, 3H, Ar), 7.40-7.32 (m, 3H, Ar), 7.14 (t, $J=7.6 \mathrm{~Hz}, 3 \mathrm{H}, \mathrm{Ar}), 7.02$ (t, $J=7.4 \mathrm{~Hz}, 3 \mathrm{H}, \mathrm{Ar}), 4.59-4.56(\mathrm{~m}, 3 \mathrm{H}, \alpha-$ CHTrp), 3.52-3.20 (m, 15H, $\mathrm{OCH}_{3}$ and $\left.\beta-\mathrm{CH}_{2} \operatorname{Trp}\right), 1.97-1.72\left(\mathrm{~m}, 12 \mathrm{H}, \mathrm{CH}_{2}\right)$. HPLC [gradient: $\mathrm{A}: \mathrm{B}, 10-100 \%$ of $\mathrm{A}$ in $10 \mathrm{~min}]: 6.825 \mathrm{~min}$. HRMS $\left(\mathrm{ESI}^{+}\right) \mathrm{m} / \mathrm{z}$ : Cald for $\mathrm{C}_{64} \mathrm{H}_{60} \mathrm{~N}_{10} \mathrm{O}_{17}$ 1240.3668; found 1240.3657.

Trimer 8. Following the general procedure, compound 4 (100 mg, $0.114 \mathrm{mmol}$ ), 1-bromo-4iodobenzene (193 mg, $0.683 \mathrm{mmol}), \mathrm{Pd}(\mathrm{OAc})_{2}\left(1.3 \mathrm{mg}, 0.006 \mathrm{mmol}\right.$ ), $\mathrm{AgBF}_{4}(132.97 \mathrm{mg}, 0.683$ mmol) and TFA (26 $\mu \mathrm{L}, 0.342 \mathrm{mmol})$ afforded $57.3 \mathrm{mg}(37 \%)$ of $\mathbf{8}$ as an amorphous solid of cream color. ${ }^{1} \mathrm{H}$ NMR $\left(300 \mathrm{MHz}, \mathrm{CDCl}_{3}\right) \delta: 8.51-8.44\left(\mathrm{~m}, 3 \mathrm{H}, \mathrm{NH}-1^{\mathrm{i}} \mathrm{Trp}\right), 7.61-7.47$ (m, 9H, Ar), $7.40(\mathrm{~d}, J=8.0 \mathrm{~Hz}, 6 \mathrm{H}, \mathrm{Ar}), 7.30-7.23(\mathrm{~m}, 3 \mathrm{H}, \mathrm{Ar}), 7.16(\mathrm{t}, J=7.2 \mathrm{~Hz}, 3 \mathrm{H}, \mathrm{Ar}), 7.08(\mathrm{t}, J=$ $7.4 \mathrm{~Hz}, 3 \mathrm{H}, \mathrm{Ar}), 5.95$ (d, $J=7.9 \mathrm{~Hz}, 3 \mathrm{H}, \mathrm{NHCO}), 4.83-4.74$ (m, 3H, $\alpha-\mathrm{CHTrp}), 3.52-3.31$ (m, $15 \mathrm{H}, \mathrm{OCH}_{3}$ and $\left.\beta-\mathrm{CH}_{2} \mathrm{Trp}\right), 1.81-1.40\left(\mathrm{~m}, 12 \mathrm{H}, \mathrm{CH}_{2}\right)$. HPLC [gradient: A:B, 10-100\% of A in $10 \mathrm{~min}$ ]: $8.590 \mathrm{~min} . \mathrm{HRMS}\left(\mathrm{ESI}^{+}\right) \mathrm{m} / \mathrm{z}$ : Cald for $\mathrm{C}_{64} \mathrm{H}_{60} \mathrm{Br}_{3} \mathrm{~N}_{7} \mathrm{O}_{11}$ 1339.7731; found 1339.7728.

Trimer 9. Following the general procedure, compound 4 (100 mg, $0.114 \mathrm{mmol})$, 4iodobenzotrifluoride (186 mg, $0.683 \mathrm{mmol}), \mathrm{Pd}(\mathrm{OAc})_{2}(1.3 \mathrm{mg}, 0.006 \mathrm{mmol}),, \mathrm{AgBF}_{4}(132.97$ $\mathrm{mg}, 0.683 \mathrm{mmol})$ and TFA $(26 \mu \mathrm{L}, 0.342 \mathrm{mmol})$ afforded $48.6 \mathrm{mg}(33 \%)$ of 9 as an amorphous solid of cream color. ${ }^{1} \mathrm{H}$ NMR $\left(300 \mathrm{MHz}, \mathrm{CDCl}_{3}\right) \delta: 8.47$ (bs, 3H, NH-1 ${ }^{\mathrm{i}}$ Trp), 7.82 (s, 3H, Ar), $7.76(\mathrm{~d}, J=7.4 \mathrm{~Hz}, 3 \mathrm{H}, \mathrm{Ar}), 7.66-7.50$ (m, 9H, Ar), 7.31-7.25 (m, 3H, Ar), 7.20-7.06 (m, 6H, Ar), $5.97(\mathrm{~d}, J=8.1 \mathrm{~Hz}, 3 \mathrm{H}, \mathrm{NHCO}), 4.83-4.74(\mathrm{~m}, 3 \mathrm{H}, \alpha-\mathrm{CHTrp}), 3.54-3.31$ (m, 15H, $\mathrm{OCH}_{3}$ and $\left.\beta-\mathrm{CH}_{2} \mathrm{Trp}\right), 1.80-1.42\left(\mathrm{~m}, 12 \mathrm{H}, \mathrm{CH}_{2}\right)$. HPLC [gradient: $\mathrm{A}: \mathrm{B}, 10-100 \%$ of $\mathrm{A}$ in $10 \mathrm{~min}$ ]: 8.741 min. HRMS (ESI ${ }^{+}$) m/z: Cald for $\mathrm{C}_{67} \mathrm{H}_{60} \mathrm{~F}_{9} \mathrm{~N}_{7} \mathrm{O}_{11}$ 1309.3738; found 1309.3759. 
Trimer 10. Following the general procedure, compound 4 (100 mg, $0.114 \mathrm{mmol})$, 4iodoanisole (159.9 mg, $0.683 \mathrm{mmol}), \mathrm{Pd}(\mathrm{OAc})_{2}(1.3 \mathrm{mg}, 0.006 \mathrm{mmol}),, \mathrm{AgBF}_{4}(132.97 \mathrm{mg}$, $0.683 \mathrm{mmol})$ and TFA $(26 \mu \mathrm{L}, 0.342 \mathrm{mmol})$ afforded $51.4 \mathrm{mg}(38 \%)$ of $\mathbf{1 0}$ as an amorphous solid of cream color. ${ }^{1} \mathrm{H}$ NMR $\left(300 \mathrm{MHz}, \mathrm{CDCl}_{3}\right) \delta$ : 8.36 (bs, 3H, NH-1 $\left.{ }^{\mathrm{i}} \mathrm{Trp}\right), 7.52-7.42$ (m, 9H, Ar), 7.28-7.23 (m, 3H, Ar), 7.17-7.03 (m, 6H, Ar), 7.01-6.93 (m, 6H, Ar), 5.87 (d, J=7.9 Hz, 3H, NHCO), 4.82-4.72 (m, 3H, $\alpha$-CHTrp), 3.85-3.76 (m, 9H, $\left.\mathrm{OCH}_{3}\right), 3.53-3.35\left(\mathrm{~m}, 15 \mathrm{H}, \mathrm{OCH}_{3}\right.$ and $\left.\beta-\mathrm{CH}_{2} \mathrm{Trp}\right), 1.83-1.40\left(\mathrm{~m}, 12 \mathrm{H}, \mathrm{CH}_{2}\right)$. HPLC [gradient: $\mathrm{A}: \mathrm{B}, 10-100 \%$ of $\mathrm{A}$ in $10 \mathrm{~min}$ ]: 7.447 min. HRMS (ESI ${ }^{+}$) m/z: Cald for $\mathrm{C}_{67} \mathrm{H}_{69} \mathrm{~N}_{7} \mathrm{O}_{14}$ 1195.4433; found 1195.4447.

Trimer 11. Following the general procedure, compound 4 (100 mg, $0.114 \mathrm{mmol})$, methyl 3iodobenzoate $(179.1 \mathrm{mg}, 0.683 \mathrm{mmol}), \mathrm{Pd}(\mathrm{OAc})_{2}(1.3 \mathrm{mg}, 0.006 \mathrm{mmol}), \mathrm{AgBF}_{4}(132.97 \mathrm{mg}$, $0.683 \mathrm{mmol})$ and TFA $(26 \mu \mathrm{L}, 0.342 \mathrm{mmol})$ afforded $56 \mathrm{mg}(38 \%)$ of 11 as an amorphous solid of cream color. ${ }^{1} \mathrm{H}$ NMR $\left(300 \mathrm{MHz}, \mathrm{CDCl}_{3}\right) \delta: 8.58$ (s, 3H, NH-1 $\left.{ }^{\mathrm{i} T r p}\right), 8.24-8.20$ (m, 3H, Ar), $8.01(\mathrm{dt}, J=7.8,1.4 \mathrm{~Hz}, 3 \mathrm{H}, \mathrm{Ar}), 7.77$ (dt, $J=7.9 \mathrm{~Hz}, 1.5 \mathrm{~Hz}, 3 \mathrm{H}, \mathrm{Ar}), 7.56-7.48$ (m, 6H, Ar), 7.31-7.27 (m, 3H, Ar), 7.19-7.05 (m, 6H, Ar), 6.01 (d, J=8.1 Hz, 3H, NHCO), 4.84-4.74 (m, $3 \mathrm{H}, \alpha-\mathrm{CHTrp}), 3.90\left(\mathrm{~s}, 9 \mathrm{H}, \mathrm{OCH}_{3}\right), 3.55-3.33\left(\mathrm{~m}, 15 \mathrm{H}, \mathrm{OCH}_{3}\right.$ and $\left.\beta-\mathrm{CH}_{2} \mathrm{Trp}\right), 1.82-1.42(\mathrm{~m}$, 12H, $\mathrm{CH}_{2}$ ). HPLC [gradient: A:B, 10-100\% of A in $10 \mathrm{~min}$ ]: $6.026 \mathrm{~min} . \mathrm{HRMS}\left(\mathrm{ESI}^{+}\right.$) m/z: Cald for $\mathrm{C}_{70} \mathrm{H}_{69} \mathrm{~N}_{7} \mathrm{O}_{17} 1279.3811$; found 1279.3808 .

Trimer 12. Following the general procedure, compound 4 (100 mg, $0.114 \mathrm{mmol})$, methyl 4iodobenzoate $(179.2 \mathrm{mg}, 0.684 \mathrm{mmol}), \mathrm{Pd}(\mathrm{OAc})_{2}(1.3 \mathrm{mg}, 0.006 \mathrm{mmol}), \mathrm{AgBF}_{4}(132.97 \mathrm{mg}$, $0.683 \mathrm{mmol})$ and TFA $(26 \mu \mathrm{L}, 0.342 \mathrm{mmol})$ afforded $54.1 \mathrm{mg}(37 \%)$ of 12 as an amorphous solid of cream color. ${ }^{1} \mathrm{H}$ NMR $\left(400 \mathrm{MHz}, \mathrm{CDCl}_{3}\right) \delta: 8.73$ (s, 3H. NH-1 $\left.{ }^{\mathrm{i}} \mathrm{Trp}\right), 8.06$ (d, J=8.5 Hz, 6H, Ar), 7.62 (d, $J=8.5 \mathrm{~Hz}, 6 \mathrm{H}, \mathrm{Ar}), 7.52$ (d, $J=7.9 \mathrm{~Hz}, 3 \mathrm{H}, \mathrm{Ar}), 7.32-7.27$ (m, 3H, Ar), 7.18$7.12(\mathrm{~m}, 3 \mathrm{H}, \mathrm{Ar}), 7.10-7.04(\mathrm{~m}, 3 \mathrm{H}, \mathrm{Ar}), 6.07$ (d, $J=8.0 \mathrm{~Hz}, 3 \mathrm{H}, \mathrm{NHCO}), 4.83-4.76(\mathrm{~m}, 3 \mathrm{H}, \alpha-$ 
CHTrp), 3.89 (s, 9H, $\mathrm{OCH}_{3}$ ), 3.52 (dd, $J=14.7,6.2 \mathrm{~Hz}, 3 \mathrm{H}, \beta-\mathrm{CH}_{2}$ Trp), 3.46-3.40 (m, 3H, $\beta$ $\left.\mathrm{CH}_{2} \operatorname{Trp}\right), 3.39\left(\mathrm{~s}, 9 \mathrm{H}, \mathrm{OCH}_{3}\right), 1.73-1.57\left(\mathrm{~m}, 8 \mathrm{H}, \mathrm{CH}_{2}\right), 1.51-1.41\left(\mathrm{~m}, 4 \mathrm{H}, \mathrm{CH}_{2}\right)$. HPLC [gradient: A:B, $10-100 \%$ of $A$ in $10 \mathrm{~min}$ ]: $6.222 \mathrm{~min}$. HRMS (ESI ${ }^{+}$) m/z: Cald for $\mathrm{C}_{70} \mathrm{H}_{69} \mathrm{~N}_{7} \mathrm{O}_{17}$ 1279.3811; found 1279.3808 .

Trimer 13. Following the general procedure, compound 4 (100 mg, $0.114 \mathrm{mmol})$, dimethyl 5iodoisophthalate (218 mg, $0.684 \mathrm{mmol}), \mathrm{Pd}(\mathrm{OAc})_{2}(1.3 \mathrm{mg}, 0.006 \mathrm{mmol}), \mathrm{AgBF}_{4}(132.97 \mathrm{mg}$, $0.683 \mathrm{mmol})$ and TFA (26 $\mu \mathrm{L}, 0.342 \mathrm{mmol})$ afforded $57.3 \mathrm{mg}(35 \%)$ of $\mathbf{1 3}$ as an amorphous solid of cream color. ${ }^{1} \mathrm{H}$ NMR (300 MHz, $\mathrm{CDCl}_{3}$ ) $\delta: 8.89$ (bs, 3H, NH-1 ${ }^{\mathrm{i} T r p}$ ), 8.56 (bs, 3H, Ar), $8.38(\mathrm{~d}, J=1.6 \mathrm{~Hz}, 6 \mathrm{H}, \mathrm{Ar}), 7.54$ (d, $J=7.8 \mathrm{~Hz}, 3 \mathrm{H}, \mathrm{Ar}), 7.30-7.24$ (m, 3H, Ar), 7.19-7.03 (m, 6H, Ar), 6.19 (d, $J=8.2 \mathrm{~Hz}, 3 \mathrm{H}, \mathrm{NHCO}), 4.84-4.74$ (m, 3H, $\alpha$-CHTrp), 3.90 (s, 18H, $\mathrm{OCH}_{3}$ ), 3.51-3.29 (m, 15H, $\mathrm{OCH}_{3}$ and $\left.\beta-\mathrm{CH}_{2} \mathrm{Trp}\right), 1.78-1.47\left(\mathrm{~m}, 12 \mathrm{H}, \mathrm{CH}_{2}\right)$. HPLC [gradient: A:B, 10100\% of A in $10 \mathrm{~min}$ ]: 7.239 min. HRMS (ESI ${ }^{+}$) m/z: Cald for $\mathrm{C}_{76} \mathrm{H}_{75} \mathrm{~N}_{7} \mathrm{O}_{23}$ 1453.3506; found 1453.3498 .

Tetramer 25. Following the general procedure, compound 24 (120 mg, $0.098 \mathrm{mmol})$, methyl 3-iodobenzoate (205.3 mg, $0.783 \mathrm{mmol}), \mathrm{Pd}(\mathrm{OAc})_{2}(2.2 \mathrm{mg}, 0.01 \mathrm{mmol}), \mathrm{AgBF}_{4}(152.4 \mathrm{mg}$, $0.783 \mathrm{mmol})$ and TFA (30 $\mu \mathrm{L}, 0.392 \mathrm{mmol})$ afforded $67.4 \mathrm{mg}(39 \%)$ of $\mathbf{2 5}$ as an amorphous solid of cream color. ${ }^{1} \mathrm{H}$ NMR (300 MHz, $\mathrm{CDCl}_{3}$ ) $\delta: 9.31$ (bs, 4H, NH-1 ${ }^{\mathrm{i} T r p}$ ), 8.26 (bs, 4H, Ar), 7.99-7.92 (m, 4H, Ar), 7.79-7.72 (m, 4H, Ar), 7.56-7.48 (m, 4H, Ar), 7.44 (t, J= 7.7 Hz, 3H, Ar), 7.22-7.14 (m, 4H, Ar), 7.11-6.98 (m, 8H, Ar), 6.58 (d, $J=7.9$ Hz, 4H, NHCO), 4.95-4.84 (m, 4H, $\alpha$-CHTrp), 3.90 (bs, 12H, OCH ${ }_{3}$ ), 3.58-3.41 (m, 8H, $\beta$ - $\mathrm{CH}_{2} \mathrm{Trp}$ ), 3.31 (bs, $12 \mathrm{H}, \mathrm{OCH}_{3}$ ), 3.04-2.93 (m, 4H, OCH $), 2.92-2.82\left(\mathrm{~m}, 4 \mathrm{H}, \mathrm{OCH}_{2}\right), 2.58\left(\mathrm{~d}, J=9.3 \mathrm{~Hz}, 4 \mathrm{H}, \mathrm{OCH}_{2}\right), 2.40(\mathrm{~d}, J$ $\left.=9.3 \mathrm{~Hz}, 4 \mathrm{H}, \mathrm{OCH}_{2}\right), 2.05-1.95\left(\mathrm{~m}, 8 \mathrm{H}, \mathrm{CH}_{2}\right) . \mathrm{HPLC}$ [gradient: A:B, $10-100 \%$ of A in $10 \mathrm{~min}$ ]: 6.382 min. HRMS (ESI ${ }^{+}$) m/z: Cald for $\mathrm{C}_{97} \mathrm{H}_{100} \mathrm{~N}_{8} \mathrm{O}_{24}$ 1760.5598; found 1760.5602 . 
Tetramer 26. Following the general procedure, compound 24 (100 mg, $0.082 \mathrm{mmol})$, methyl 4-iodobenzoate $(171.1 \mathrm{mg}, 0.653 \mathrm{mmol}), \mathrm{Pd}(\mathrm{OAc})_{2}(1.8 \mathrm{mg}, 0.008 \mathrm{mmol}), \mathrm{AgBF}_{4}(127.1 \mathrm{mg}$, $0.653 \mathrm{mmol})$ and TFA $(25 \mu \mathrm{L}, 0.326 \mathrm{mmol})$ gave $46.2 \mathrm{mg}(32 \%)$ of 26 as an amorphous solid of cream color. ${ }^{1} \mathrm{H}$ NMR (300 MHz, $\left.\mathrm{CDCl}_{3}\right) \delta: 9.39$ (s, 4H, NH-1 $\left.{ }^{\mathrm{i}} \mathrm{Trp}\right), 8.07-7.98$ (m, 8H, Ar), 7.68-7.58 (m, 8H, Ar), 7.56-7.47 (m, 4H, Ar), 7.16-6.99 (m, 12H, Ar), 6.55 (d, J= 7.7 Hz, 3H, NHCO), 4.93-4.84 (m, 4H, $\alpha-\mathrm{CHTrp}), 3.90$ (s, 12H, $\left.\mathrm{OCH}_{3}\right), 3.63-3.43$ (m, 8H, $\left.\beta-\mathrm{CH}_{2} \mathrm{Trp}\right), 3.36$ $\left(\mathrm{d}, J=3.9 \mathrm{~Hz}, 12 \mathrm{H}, \mathrm{OCH}_{3}\right), 2.98-2.88\left(\mathrm{~m}, 4 \mathrm{H}, \mathrm{OCH}_{2}\right), 2.87-2.76\left(\mathrm{~m}, 4 \mathrm{H}, \mathrm{OCH}_{2}\right), 2.62(\mathrm{~d}, J=$ $\left.9.3 \mathrm{~Hz}, 4 \mathrm{H}, \mathrm{OCH}_{2}\right), 2.47\left(\mathrm{~d}, J=9.2 \mathrm{~Hz}, 4 \mathrm{H}, \mathrm{OCH}_{2}\right), 2.03-1.82\left(\mathrm{~m}, 8 \mathrm{H}, \mathrm{CH}_{2}\right)$. HPLC [gradient: $\mathrm{A}: \mathrm{B}, 10-100 \%$ of $\mathrm{A}$ in $10 \mathrm{~min}]: 8.246 \mathrm{~min}$. $\mathrm{HRMS}\left(\mathrm{ESI}^{+}\right) \mathrm{m} / \mathrm{z}$ : Cald for $\mathrm{C}_{97} \mathrm{H}_{100} \mathrm{~N}_{8} \mathrm{O}_{24}$ 1760.5598; found 1760.5600 .

Tetramer 27. Following the general procedure, compound 24 (120 mg, $0.098 \mathrm{mmol}$ ), dimethyl 5-iodoisophthalate $(251 \mathrm{mg}, 0.783 \mathrm{mmol}), \mathrm{Pd}(\mathrm{OAc})_{2}(2.2 \mathrm{mg}, 0.010 \mathrm{mmol}), \mathrm{AgBF}_{4}$ (152.4 $\mathrm{mg}, 0.783 \mathrm{mmol})$ and TFA $(30 \mu \mathrm{L}, 0.392 \mathrm{mmol})$ gave $51.7 \mathrm{mg}(26 \%)$ of 27 as an amorphous solid of cream color. ${ }^{1} \mathrm{H}$ NMR $\left(300 \mathrm{MHz}, \mathrm{CDCl}_{3}\right) \delta: 9.45$ (bs, 4H, NH-1 $\left.{ }^{\mathrm{i}} \mathrm{Trp}\right), 8.57$ (bs, 4H, Ar), 8.43 (d, $J=1.6 \mathrm{~Hz}, 8 \mathrm{H}, \mathrm{Ar}), 7.56-7.50$ (m, 4H, Ar), 7.21-7.15 (m, 4H, Ar), 7.10$6.98(\mathrm{~m}, 8 \mathrm{H}, \mathrm{Ar}), 6.62$ (d, $J=8.0 \mathrm{~Hz}, 4 \mathrm{H}, \mathrm{NHCO}), 4.99-4.87$ (m, 4H, $\alpha-\mathrm{CHTrp}), 3.91$ (s, 24H, $\left.\mathrm{OCH}_{3}\right), 3.59-3.39\left(\mathrm{~m}, 8 \mathrm{H}, \beta-\mathrm{CH}_{2} \mathrm{Trp}\right), 3.31$ (bs, 12H, $\left.\mathrm{OCH}_{3}\right), 3.03-2.91\left(\mathrm{~m}, 4 \mathrm{H}, \mathrm{OCH}_{2}\right), 2.90-$ $2.82\left(\mathrm{~m}, 4 \mathrm{H}, \mathrm{OCH}_{2}\right), 2.49\left(\mathrm{~d}, J=9.3 \mathrm{~Hz}, 4 \mathrm{H}, \mathrm{OCH}_{2}\right), 2.31\left(\mathrm{~d}, J=9.3 \mathrm{~Hz}, 4 \mathrm{H}, \mathrm{OCH}_{2}\right), 2.12-1.96$ (m, 8H, $\mathrm{CH}_{2}$ ). HPLC [gradient: A:B, 10-100\% of A in $10 \mathrm{~min}$ ]: $9.368 \mathrm{~min} . \mathrm{HRMS}\left(\mathrm{ESI}^{+}\right) \mathrm{m} / \mathrm{z}$ : Cald for $\mathrm{C}_{105} \mathrm{H}_{108} \mathrm{~N}_{8} \mathrm{O}_{32}$ 1992. 5192; found 1760.5199 .

General procedure for the deprotection of the methyl esters. To a solution containing the corresponding methyl ester derivative $(1.0 \mathrm{mmol})$ in $\mathrm{THF}(10 \mathrm{~mL})$ at $0{ }^{\circ} \mathrm{C}$ (ice-bath), a solution of $\mathrm{LiOH} \cdot \mathrm{H}_{2} \mathrm{O}$ (2 eq for each methyl ester group) in water $(2 \mathrm{~mL})$ was added, and the mixture was 
stirred at room temperature overnight. Then $1 \mathrm{~N}$ hydrochloric acid aqueous solution was added to reach $\mathrm{pH}=2$, and volatiles were evaporated to dryness. The residue was dissolved in ethyl acetate $(15 \mathrm{~mL})$ and washed with $\mathrm{H}_{2} \mathrm{O}(3 \times 10 \mathrm{~mL})$. The organic phase was dried over anhydrous $\mathrm{Na}_{2} \mathrm{SO}_{4}$, filtered and evaporated to dryness. The compounds were precipitated with diethyl ether to afford the pure deprotected derivatives.

Trimer I. Following the general procedure for the deprotection of methyl esters, compound 4 (100 mg, $0.11 \mathrm{mmol}$ ) gave $95 \mathrm{mg}$ (quant) of I as an amorphous white solid. ${ }^{1} \mathrm{H}$ NMR (500 MHz, DMSO- $\left.d_{6}\right) \delta: 10.79$ (bs, 3H, NH-1 Trp), 8.15 (d, $J=7.9 \mathrm{~Hz}, 3 \mathrm{H}, \mathrm{NHCO}$ ), 7.50 (d, $J=7.8 \mathrm{~Hz}$, 3H, Ar), 7.29 (d, $J=8.1 \mathrm{~Hz}, 3 \mathrm{H}, \mathrm{Ar}), 7.10$ (d, $J=7.8 \mathrm{~Hz}, 3 \mathrm{H}, \mathrm{Ar}), 7.01$ (m, 3H, Ar), 6.94 (m, 3H, Ar), 4.51-4.45 (m, 3H, $\alpha$-CHTrp), 3.13 (dd, $\left.J=14.6,5.2 \mathrm{~Hz}, 3 \mathrm{H}, \beta-\mathrm{CH}_{2} \operatorname{Trp}\right), 2.97$ (dd, $J=$ 14.6, $\left.8.5 \mathrm{~Hz}, 3 \mathrm{H}, \beta-\mathrm{CH}_{2} \mathrm{Trp}\right), 1.97$ (m, 12H. $\left.\mathrm{CH}_{2}\right) .{ }^{13} \mathrm{C}$ NMR (125 MHz, DMSO) $\delta: 174.0,170.1$, 136.5, 127.7, 124.0, 121.3, 118.7, 118.6, 111.8, 110.6, 54.0, 31.0, 29.9, 27.6. HPLC [gradient: $\mathrm{A}: \mathrm{B}, 10-100 \%$ of $\mathrm{A}$ in $10 \mathrm{~min}$ ]: $7.020 \mathrm{~min}$. HRMS $\left(\mathrm{ESI}^{+}\right) \mathrm{m} / \mathrm{z}$ : calculated for $\mathrm{C}_{43} \mathrm{H}_{45} \mathrm{~N}_{7} \mathrm{O}_{11}$ 835.3177; found 835.3165. Anal. Cal. for $\mathrm{C}_{43} \mathrm{H}_{45} \mathrm{~N}_{7} \mathrm{O}_{11}$ : C, 61.79; H, 5.43. Found: C, 61.43; H, 5.69 .

Tetramer II. Following the general procedure for the deprotection of methyl esters, compound 24 (100 mg, $0.082 \mathrm{mmol}$ ) gave $95.3 \mathrm{mg}$ (quant) of II as an amorphous white solid. ${ }^{1} \mathrm{H}-\mathrm{NMR}$ (300 MHz, DMSO-d 6 , ) $\delta: 10.79$ (d, $\left.J=2.4 \mathrm{~Hz}, 4 \mathrm{H}, \mathrm{NH}-1^{\mathrm{i} T r p}\right), 8.13$ (d, $J=7.8 \mathrm{~Hz}, 4 \mathrm{H}, \mathrm{NHCO}$ ), $7.52(\mathrm{~d}, J=7.8 \mathrm{~Hz}, 4 \mathrm{H}, \mathrm{Ar}), 7.31$ (d, $J=8.0 \mathrm{~Hz}, 4 \mathrm{H}, \mathrm{Ar}), 7.12$ (d, $J=2.3 \mathrm{~Hz}, 4 \mathrm{H}, \mathrm{Ar}), 7.1-7.0$ (m, 4H, Ar), 7.0-6.9 (m, 4H, Ar), 4.55-4.48 (m, 4H, $\alpha$-CHTrp), 3.39 (t, $J=6.8 \mathrm{~Hz}, 4 \mathrm{H}, \mathrm{OCH}_{2}$ ), 3.24-2.90 (m, $12 \mathrm{H}, \beta-\mathrm{CH}_{2} \operatorname{Trp}$ and $\left.\mathrm{OCH}_{2}\right), 2.35-2.18\left(\mathrm{~m}, 4 \mathrm{H}, \mathrm{CH}_{2}\right) .{ }^{13} \mathrm{C}$ NMR $(126 \mathrm{MHz}$, $\left.\mathrm{CD}_{3} \mathrm{OD}\right) \delta: 175.3,174.2,138.0,129.0,124.5,122.5,119.9,119.3,112.5,110.9,70.6,68.0,45.8$ 40.5, 37.4, 28.6. HPLC [gradient: A:B, 10-100\% of A in $10 \mathrm{~min}$ ]: $7.700 \mathrm{~min} . \mathrm{HRMS}\left(\mathrm{ESI}^{+}\right) \mathrm{m} / \mathrm{z}$ : 
calculated for $\mathrm{C}_{61} \mathrm{H}_{68} \mathrm{~N}_{8} \mathrm{O}_{16}$ 1169.2550; found 1170.4815. Anal. Cal. for $\mathrm{C}_{61} \mathrm{H}_{69} \mathrm{~N}_{8} \mathrm{O}_{16}$ : C, 62.66; H, 5.86. Found: C, 62.43; H, 5.69.

Trimer 14. Following the general procedure for the deprotection of methyl esters, compound 5 (60 mg, $0.0542 \mathrm{mmol}$ ) gave $57 \mathrm{mg}$ (quant) of $\mathbf{1 4}$ as an amorphous white solid. ${ }^{1} \mathrm{H}$ NMR (400 MHz, DMSO- $\left.d_{6}\right) \delta: 11.16$ (s, 3H, NH-1 $\left.{ }^{\mathrm{i} T r p}\right), 8.27$ (d, $\left.J=8.2 \mathrm{~Hz}, 3 \mathrm{H}, \mathrm{NHCO}\right), 7.62$ (d, $J=7.7$ $\mathrm{Hz}, 9 \mathrm{H}, \mathrm{Ar}), 7.44$ (t, $J=7.6 \mathrm{~Hz}, 6 \mathrm{H}, \mathrm{Ar}), 7.36-7.26(\mathrm{~m}, 6 \mathrm{H}, \mathrm{Ar}), 7.04(\mathrm{t}, J=7.5 \mathrm{~Hz}, 3 \mathrm{H}, \mathrm{Ar})$, $6.96(\mathrm{t}, J=7.4 \mathrm{~Hz}, 3 \mathrm{H}, \mathrm{Ar}), 4.57-4.49$ (m, 3H, $\alpha$-CHTrp), 3.30 (dd, $J=14.4,6.7 \mathrm{~Hz}, 3 \mathrm{H}, \beta-$ $\left.\mathrm{CH}_{2} \mathrm{Trp}\right), 3.12\left(\mathrm{dd}, J=14.4,7.7 \mathrm{~Hz}, 3 \mathrm{H}, \beta-\mathrm{CH}_{2} \mathrm{Trp}\right), 1.88-1.70$ (m, $\left.12 \mathrm{H} . \mathrm{CH}_{2}\right) .{ }^{13} \mathrm{C}$ NMR $(100$ MHz, DMSO- $\left.d_{6}\right) \delta: 174.0,171.0,136.5,135.9,133.5,129.6,129.3,128.6,128.1,122.1,119.62$, 119.4, 111.7, 108.2, 93.6, 53.8, 31.2, 29.9, 28.0. HPLC [gradient: A:B, 10-100\% of A in 10 min]: 5.150 min. HRMS (ESI-) m/z: Cald for $\mathrm{C}_{61} \mathrm{H}_{57} \mathrm{~N}_{7} \mathrm{O}_{11}$ : 1063.4116; found 1063.4102. Anal. Cal. for $\mathrm{C}_{61} \mathrm{H}_{57} \mathrm{~N}_{7} \mathrm{O}_{11} \mathrm{C}, 68.85 ; \mathrm{H}$, 5.40. Found: $\mathrm{C}, 68.64 ; \mathrm{H}, 5.20$.

Trimer 15. Following the general procedure for the deprotection of methyl esters, compound 6 (58 mg, $0.05 \mathrm{mmol}$ ) gave $55 \mathrm{mg}$ (quant) of 15 as an amorphous white solid. ${ }^{1} \mathrm{H}$ NMR (400 MHz, DMSO- $\left.d_{6}\right) \delta: 11.24$ (s, 3H, NH-1 $\left.{ }^{\mathrm{i} T r p}\right), 8.18$ (d, $\left.J=8.1 \mathrm{~Hz}, 3 \mathrm{H}, \mathrm{NHCO}\right), 7.71(\mathrm{~d}, J=7.9 \mathrm{~Hz}, 3 \mathrm{H}$, Ar), 7.62-7.56 (m, 3H, Ar), 7.53-7.46 (m, 3H, Ar), 7.42-7.32 (m, 9H, Ar), 7.15 (t, $J=7.5 \mathrm{~Hz}$ 3H, Ar), 7.07 (t, $J=7.4 \mathrm{~Hz}, 3 \mathrm{H}, \mathrm{Ar}), 4.54-4.46$ (m, 3H, $\alpha$-CHTrp), 3.22 (dd, $J=14.4,6.6 \mathrm{~Hz}$, $\left.3 \mathrm{H}, \beta-\mathrm{CH}_{2} \mathrm{Trp}\right), 3.11\left(\mathrm{dd}, J=14.4,7.5 \mathrm{~Hz}, 3 \mathrm{H}, \beta-\mathrm{CH}_{2} \operatorname{Trp}\right), 1.95-1.77$ (m, $\left.12 \mathrm{H}, \mathrm{CH} 2\right) .{ }^{13} \mathrm{C}$ NMR $\left(100 \mathrm{MHz}, \mathrm{DMSO}-d_{6}\right) \delta: 173.6,170.6,161.0,158.5,136.5,132.4,132.4,130.6,130.6,130.1$, $128.4,125.4,124.9,124.9,122.0,121.1,121.0,119.4,119.2,116.5,116.3,111.6,109.6,93.3$ 53.4, 34.9, 31.0, 30.9, 29.6, 29.5, 27.6. HPLC [gradient: A:B, 10-100\% of A in $10 \mathrm{~min}$ ]: 6.131 min. HRMS (ESI-) m/z: Cald for $\mathrm{C}_{61} \mathrm{H}_{54} \mathrm{~F}_{3} \mathrm{~N}_{7} \mathrm{O}_{11}$ : 1117.3833; found 1117.3828. Anal. Cal. for $\mathrm{C}_{61} \mathrm{H}_{54} \mathrm{~F}_{3} \mathrm{~N}_{7} \mathrm{O}_{11}:$ C, 65.53; H, 4.87. Found: C, 65.28; H, 4.69. 
Trimer 16. Following the general procedure for the deprotection of methyl esters, compound 7 (53 mg, $0.043 \mathrm{mmol}$ ) gave $51 \mathrm{mg}$ (quant) of $\mathbf{1 6}$ as an amorphous white solid. ${ }^{1} \mathrm{H}$ NMR (400 MHz, DMSO- $\left.d_{6}\right) \delta: 11.48\left(\mathrm{~s}, 3 \mathrm{H}, \mathrm{NH}-1^{\mathrm{i}} \mathrm{Trp}\right), 8.36-8.39(\mathrm{~m}, 9 \mathrm{H}, \mathrm{NHCO}$ and Ar), $7.94(\mathrm{~d}, J=8.8$ $\mathrm{Hz}, 6 \mathrm{H}, \mathrm{Ar}), 7.70$ (d, $J=8.0 \mathrm{~Hz}, 3 \mathrm{H}, \mathrm{Ar}), 7.38$ (d, $J=8.1 \mathrm{~Hz}, 3 \mathrm{H}, \mathrm{Ar}), 7.14$ (t, $J=7.5 \mathrm{~Hz}, 3 \mathrm{H}$, Ar), 7.03 (t, $J=7.4 \mathrm{~Hz}, 3 \mathrm{H}, \mathrm{Ar}), 4.61-4.53$ (m, 3H, $\alpha$-CHTrp), 3.40 (dd, $J=14.6,6.8 \mathrm{~Hz}, 3 \mathrm{H}, \beta$ $\left.\mathrm{CH}_{2} \mathrm{Trp}\right), 3.24\left(\mathrm{dd}, J=14.5,7.7 \mathrm{~Hz}, 3 \mathrm{H}, \beta-\mathrm{CH}_{2} \mathrm{Trp}\right), 1.94-1.71\left(\mathrm{~m}, 12 \mathrm{H}, \mathrm{CH}_{2}\right) .{ }^{13} \mathrm{C}$ NMR $(100$ $\left.\mathrm{MHz}, \mathrm{DMSO}-d_{6}\right) \delta: 173.5,170.9,146.4,139.8,139.6,137.0,133.2,129.3,128.9,125.4,124.3$, 123.2, 119.9, 119.7, 111.9, 111.1, 93.4, 53.4, 34.9, 30.9, 29.7, 29.7, 29.5, 27.8. HPLC [gradient: $\mathrm{A}: \mathrm{B}, 10-100 \%$ of $\mathrm{A}$ in $10 \mathrm{~min}]: 6.456 \mathrm{~min} . \mathrm{HRMS}\left(\mathrm{ESI}^{-}\right) \mathrm{m} / \mathrm{z}$ : Cald for $\mathrm{C}_{61} \mathrm{H}_{54} \mathrm{~N}_{10} \mathrm{O}_{17} 1198.3668$; found 1198.3655. Anal. Cal. for $\mathrm{C}_{61} \mathrm{H}_{54} \mathrm{~N}_{10} \mathrm{O}_{17}$ : C, 61.10; H, 4.54. Found: C, 61.03; H, 4.39.

Trimer 17. Following the general procedure for the deprotection of methyl esters, compound $\mathbf{8}$ (61 mg, $0.045 \mathrm{mmol}$ ) gave $59 \mathrm{mg}$ (quant) of 17 as an amorphous white solid. ${ }^{1} \mathrm{H}$ NMR (400 MHz, DMSO- $\left.d_{6}\right) \delta: 11.24\left(\mathrm{~s}, 3 \mathrm{H}, \mathrm{NH}-1^{\mathrm{i} T r p}\right), 8.30$ (d, $\left.J=8.2 \mathrm{~Hz}, 3 \mathrm{H}, \mathrm{NHCO}\right), 7.70-7.64$ (m, 9H, Ar), 7.63-7.59 (m, 6H, Ar), 7.34 (d, J=8.0 Hz, 3H, Ar), 7.09 (t, $J=7.5 \mathrm{~Hz}, 3 \mathrm{H}, \mathrm{Ar}), 7.00$ (t, $J=7.5 \mathrm{~Hz}, 3 \mathrm{H}, \mathrm{Ar}), 4.59-4.52(\mathrm{~m}, 3 \mathrm{H}, \alpha-\mathrm{CHTrp}), 3.31$ (dd, $\left.J=14.5,6.9 \mathrm{~Hz}, 3 \mathrm{H}, \beta-\mathrm{CH}_{2} \operatorname{Trp}\right)$, 3.19-3.10 (m, 3H, $\left.\beta-\mathrm{CH}_{2} \mathrm{Trp}\right), 1.95-1.74\left(\mathrm{~m}, 12 \mathrm{H}, \mathrm{CH}_{2}\right) .{ }^{13} \mathrm{C}$ NMR (100 MHz, DMSO- $\left.d_{6}\right) \delta$ : $173.6,170.8,139.6,136.4,134.4,132.5,132.0,130.4,129.3,128.5,125.4,122.2,121.1,119.51$ 119.4, 111.6, 108.6, 93.4, 53.5, 49.1, 34.9, 31.0, 30.9, 29.8, 29.7, 27.8, 21.5. HPLC [gradient: $\mathrm{A}: \mathrm{B}, 10-100 \%$ of $\mathrm{A}$ in $10 \mathrm{~min}]: 7.242 \mathrm{~min}$. HRMS (ESI-) $\mathrm{m} / \mathrm{z}$ : Cald for $\mathrm{C}_{61} \mathrm{H}_{54} \mathrm{Br}_{3} \mathrm{~N}_{7} \mathrm{O}_{11}$ 1297.1431; found 1297.1388. Anal. Cal. for $\mathrm{C}_{61} \mathrm{H}_{54} \mathrm{Br}_{3} \mathrm{~N}_{7} \mathrm{O}_{11}$ : C, 56.32; H, 4.18. Found: C, 56.20; H, 4.03.

Trimer 18. Following the general procedure for the deprotection of methyl esters, compound 9 (57.2 mg, $0.044 \mathrm{mmol}$ ) gave $55 \mathrm{mg}$ (quant) of 18 as an amorphous white solid. ${ }^{1} \mathrm{H}$ NMR (400 
MHz, DMSO- $\left.d_{6}\right) \delta: 11.38$ (s, 3H, NH-1 $\left.{ }^{\mathrm{i} T r p}\right), 8.34$ (d, $\left.J=8.3 \mathrm{~Hz}, 3 \mathrm{H}, \mathrm{NHCO}\right), 8.01-7.94$ (m, 6H, Ar), 7.74-7.67 (m, 9H, Ar), $7.36(\mathrm{~d}, J=8.1 \mathrm{~Hz}, 3 \mathrm{H}, \mathrm{Ar}), 7.11(\mathrm{t}, J=7.5 \mathrm{~Hz}, 3 \mathrm{H}, \mathrm{Ar}), 7.02$ (t, $J=7.5 \mathrm{~Hz}, 3 \mathrm{H}, \mathrm{Ar}), 4.61-4.54(\mathrm{~m}, 3 \mathrm{H}, \alpha-\mathrm{CHTrp}), 3.35$ (dd, $\left.J=14.5,6.8 \mathrm{~Hz}, 3 \mathrm{H}, \beta-\mathrm{CH}_{2} \operatorname{Trp}\right)$, $3.18\left(\mathrm{dd}, J=14.5,7.5 \mathrm{~Hz}, 3 \mathrm{H}, \beta-\mathrm{CH}_{2} \mathrm{Trp}\right), 1.93-1.73\left(\mathrm{~m}, 12 \mathrm{H}, \mathrm{CH}_{2}\right) .{ }^{13} \mathrm{C} \mathrm{NMR}(100 \mathrm{MHz}$, DMSO- $\left.d_{6}\right) \delta: 173.6,170.8,162.8,139.6,136.5,134.2,133.8,132.2,130.5,130.2,129.9,129.5$ $129.2,128.7,126.0,125.4,124.7,124.6,124.3,124.3,123.3,122.5,120.6,119.7,119.5,111.7$, 109.3, 93.4, 53.5, 36.2, 34.9, 31.2, 30.9, 29.7, 28.2, 27.8. HPLC [gradient: A:B, 10-100\% of A in $10 \mathrm{~min}$ ]: $7.619 \mathrm{~min}$. HRMS (ESI-) m/z: Cald for $\mathrm{C}_{64} \mathrm{H}_{54} \mathrm{~F}_{9} \mathrm{~N}_{7} \mathrm{O}_{11}$ 1267.3738; found 1267.3761. Anal. Cal. for $\mathrm{C}_{64} \mathrm{H}_{54} \mathrm{~F}_{9} \mathrm{~N}_{7} \mathrm{O}_{11}$ : C, 60.62; H, 4.29. Found: C, 60.43; H, 4.13.

Trimer 19. Following the general procedure for the deprotection of methyl esters, compound 10 (50 mg, $0.04 \mathrm{mmol}$ ) gave $46 \mathrm{mg}$ (quant) of 19 as an amorphous white solid. ${ }^{1} \mathrm{H}$ NMR (400 MHz, DMSO- $\left.d_{6}\right) \delta: 11.13\left(\mathrm{~s}, 3 \mathrm{H}, \mathrm{NH}-1^{\mathrm{i}} \mathrm{Trp}\right), 8.33(\mathrm{~d}, J=8.3 \mathrm{~Hz}, 3 \mathrm{H}, \mathrm{NHCO}), 7.68(\mathrm{~d}, J=7.9$ Hz, 3H, Ar), 7.64 (d, $J=8.5 \mathrm{~Hz}, 6 \mathrm{H}, \mathrm{Ar}), 7.36$ (d, $J=7.9 \mathrm{~Hz}, 3 \mathrm{H}, \mathrm{Ar}), 7.14-7.06$ (m, 9H, Ar), $7.03(\mathrm{t}, J=7.4 \mathrm{~Hz}, 3 \mathrm{H}, \mathrm{Ar}), 4.65-4.57(\mathrm{~m}, 3 \mathrm{H}, \alpha-\mathrm{CHTrp}), 3.85\left(\mathrm{~s}, 9 \mathrm{H}, \mathrm{OCH}_{3}\right), 3.41-3.30(\mathrm{~m}$, $\left.3 \mathrm{H}, \beta-\mathrm{CH}_{2} \mathrm{Trp}\right), 3.16\left(\mathrm{dd}, J=14.4,7.6 \mathrm{~Hz}, 3 \mathrm{H}, \beta-\mathrm{CH}_{2} \mathrm{Trp}\right), 2.03-1.82\left(\mathrm{~m}, 12 \mathrm{H}, \mathrm{CH}_{2}\right) .{ }^{13} \mathrm{C}$ NMR $\left(100 \mathrm{MHz}, \mathrm{DMSO}-d_{6}\right) \delta: 173.8,170.8,159.1,136.1,135.7,129.7,129.5,125.7,121.5,119.2$, 119.1, 114.6, 111.3, 107.1, 93.4, 55.6, 53.6, 31.2, 31.0, 30.9, 29.8, 29.7, 27.9. HPLC [gradient: $\mathrm{A}: \mathrm{B}, 10-100 \%$ of $\mathrm{A}$ in $10 \mathrm{~min}]: 5.999 \mathrm{~min} . \mathrm{HRMS}\left(\mathrm{ESI}^{-}\right) \mathrm{m} / \mathrm{z}$ : Cald for $\mathrm{C}_{64} \mathrm{H}_{63} \mathrm{~N}_{7} \mathrm{O}_{14} 1153.4433$; found 1153.4458. Anal. Cal. for $\mathrm{C}_{64} \mathrm{H}_{63} \mathrm{~N}_{7} \mathrm{O}_{14}$ : C, 66.60; H, 5.50. Found: C, 66.40; H, 5.28.

Trimer 20. Following the general procedure for the deprotection of methyl esters, compound 11 (52 mg, $0.04 \mathrm{mmol}$ ) gave $49.2 \mathrm{mg}$ (quant) of $\mathbf{2 0}$ as an amorphous white solid. ${ }^{1} \mathrm{H}$ NMR (400 MHz, DMSO- $\left.d_{6}\right) \delta: 11.31$ (s, 3H, NH-1 $\left.{ }^{\mathrm{i}} \operatorname{Trp}\right), 8.30$ (d, $\left.J=8.2 \mathrm{~Hz}, 3 \mathrm{H}, \mathrm{NHCO}\right), 8.18$ (bs, 3H, Ar), $7.92(\mathrm{~d}, J=7.7 \mathrm{~Hz}, 3 \mathrm{H}, \mathrm{Ar}), 7.88(\mathrm{~d}, J=8.1 \mathrm{~Hz}, 3 \mathrm{H}, \mathrm{Ar}), 7.64$ (d, $J=7.9 \mathrm{~Hz}, 3 \mathrm{H}, \mathrm{Ar}), 7.58$ (t, $J$ 
$=7.7 \mathrm{~Hz}, 3 \mathrm{H}, \mathrm{Ar}), 7.32(\mathrm{~d}, J=8.0 \mathrm{~Hz}, 3 \mathrm{H}, \mathrm{Ar}), 7.07$ (t, $J=7.5 \mathrm{~Hz}, 3 \mathrm{H}, \mathrm{Ar}), 6.98(\mathrm{t}, J=7.4 \mathrm{~Hz}$, 3H, Ar), 4.56-4.48 (m, 3H, $\alpha$-CHTrp), 3.32 (dd, $\left.J=14.4,7.2 \mathrm{~Hz}, 3 \mathrm{H}, \beta-\mathrm{CH}_{2} \mathrm{Trp}\right), 3.14$ (dd, $J=$ 14.4, $\left.7.4 \mathrm{~Hz}, 3 \mathrm{H}, \beta-\mathrm{CH}_{2} \mathrm{Trp}\right), 1.93-1.70\left(\mathrm{~m}, 12 \mathrm{H}, \mathrm{CH}_{2}\right) .{ }^{13} \mathrm{C}$ NMR (100 MHz, DMSO- $\left.d_{6}\right) \delta$ : 173.6, 170.8, 167.7, 136.5, 134.7, 133.6, 132.6, 131.9, 129.4, 129.3, 129.2, 128.6, 122.2, 119.5, $119.4,111.6,108.5,93.4,53.6,31.0,29.7,27.7$. HPLC [gradient: A:B, 10-100\% of A in 10 min]: 4.738 min. HRMS (ESI-) m/z: Cald for $\mathrm{C}_{64} \mathrm{H}_{57} \mathrm{~N}_{7} \mathrm{O}_{17}$ 1195.3811; found 1195.3810. Anal. Cal. for $\mathrm{C}_{64} \mathrm{H}_{57} \mathrm{~N}_{7} \mathrm{O}_{17}: \mathrm{C}, 64.26 ; \mathrm{H}, 4.80$. Found: $\mathrm{C}, 63.98 ; \mathrm{H}, 4.20$.

Trimer 21. Following the general procedure for the deprotection of methyl esters, compound 12 (73.7 mg, $0.057 \mathrm{mmol}$ ) gave $68 \mathrm{mg}$ (quant) of 21 as an amorphous white solid. ${ }^{1} \mathrm{H}$ NMR (400 MHz, DMSO- $\left.d_{6}\right) \delta: 11.31$ (s, 3H, NH-1 $\left.{ }^{\mathrm{T}} \mathrm{Trp}\right), 8.34$ (d, $\left.J=8.2 \mathrm{~Hz}, 3 \mathrm{H}, \mathrm{NHCO}\right), 8.02$ (d, $J=8.2$ $\mathrm{Hz}, 6 \mathrm{H}, \mathrm{Ar}), 7.78$ (d, $J=8.3 \mathrm{~Hz}, 6 \mathrm{H}, \mathrm{Ar}), 7.66$ (d, $J=8.0 \mathrm{~Hz}, 3 \mathrm{H}, \mathrm{Ar}), 7.33$ (d, $J=8.1 \mathrm{~Hz}, 3 \mathrm{H}$, Ar), 7.08 (t, $J=7.3 \mathrm{~Hz}, 3 \mathrm{H}, \mathrm{Ar}), 6.98$ (t, $J=7.5 \mathrm{~Hz}, 3 \mathrm{H}, \mathrm{Ar}), 4.59-4.51$ (m, 3H, $\alpha$-CHTrp), 3.34 (dd, $J=14.4,7.0 \mathrm{~Hz}, 3 \mathrm{H}, \beta-\mathrm{CH}_{2} \mathrm{Trp}$ ), 3.16 (dd, $\left.J=14.4,7.6 \mathrm{~Hz}, 3 \mathrm{H}, \beta-\mathrm{CH}_{2} \mathrm{Trp}\right), 1.93-1.73$ (m, 12H, $\left.\mathrm{CH}_{2}\right) .{ }^{13} \mathrm{C}$ NMR (100 MHz, DMSO-d $\left.d_{6}\right) \delta: 173.6,170.8,167.5,137.4,136.6,134.3,130.06$, 129.6, 129.3, 128.2, 122.5, 119.7, 119.4, 111.7, 109.6, 93.3, 53.5, 30.9, 30.9, 29.7, 27.9. HPLC [gradient: $\mathrm{A}: \mathrm{B}, 10-100 \%$ of $\mathrm{A}$ in $10 \mathrm{~min}$ ]: $4.651 \mathrm{~min} . \mathrm{HRMS}(\mathrm{ESI}-) \mathrm{m} / \mathrm{z}$ : Cald for $\mathrm{C}_{64} \mathrm{H}_{57} \mathrm{~N}_{7} \mathrm{O}_{17}$ 1195.3811; found 1195.3806. Anal. Cal. for $\mathrm{C}_{64} \mathrm{H}_{57} \mathrm{~N}_{7} \mathrm{O}_{17}: \mathrm{C}, 64.26$; H, 4.80. Found: C, 64.04; $\mathrm{H}$, 4.60 .

Trimer 22. Following the general procedure for the deprotection of methyl esters, compound 13 (35.1 mg, $0.024 \mathrm{mmol}$ ) gave $32 \mathrm{mg}$ (quant) of 22 as an amorphous white solid. ${ }^{1} \mathrm{H}$ NMR (400 MHz, DMSO- $\left.d_{6}\right) \delta: 11.43$ (s, 3H, NH-1 $\left.{ }^{\mathrm{i} T r p}\right), 8.44$ (m, 3H, Ar), 8.39-8.36 (m, 6H, Ar), 8.31 (d, $J$ $=8.0 \mathrm{~Hz}, 3 \mathrm{H}, \mathrm{NHCO}), 7.65(\mathrm{~d}, J=8.0 \mathrm{~Hz}, 3 \mathrm{H}, \mathrm{Ar}), 7.34(\mathrm{~d}, J=8.1 \mathrm{~Hz}, 3 \mathrm{H}, \mathrm{Ar}), 7.13-7.06(\mathrm{~m}$, 3H, Ar), 7.02-6.96 (m, 3H, Ar), 4.53-4.46 (m, 3H, $\alpha$-CHTrp), 3.35 (dd, $J=14.4,7.8 \mathrm{~Hz}, 3 \mathrm{H}, \beta$ - 
$\left.\mathrm{CH}_{2} \mathrm{Trp}\right), 3.17$ (dd, $\left.J=14.4,7.0 \mathrm{~Hz}, 3 \mathrm{H}, \beta-\mathrm{CH}_{2} \mathrm{Trp}\right), 1.97-1.69\left(\mathrm{~m}, 12 \mathrm{H}, \mathrm{CH}_{2}\right) .{ }^{13} \mathrm{C}$ NMR $(100$ MHz, DMSO- $\left.d_{6}\right) \delta: 173.3,170.8,167.0,136.6,134.2,133.9,133.0,132.3,129.2,129.0,122.4$, $119.6,119.5,111.7,109.0,93.3,53.4,30.9,30.9,29.7,27.5$. HPLC [gradient: A:B, 10-100\% of A in 10 min]: 3.815 min. HRMS (ESI-) m/z: Cald for $\mathrm{C}_{67} \mathrm{H}_{57} \mathrm{~N}_{7} \mathrm{O}_{23}$ 1327.3506; found 1327.3498. Anal. Cal. for $\mathrm{C}_{67} \mathrm{H}_{57} \mathrm{~N}_{7} \mathrm{O}_{23}$ : C, 60.59; H, 4.33. Found: $\mathrm{C}, 60.03 ; \mathrm{H}, 4.01$.

Tetramer 28. Following the general procedure for the deprotection of methyl esters, compound 25 (34.2 mg, $0.019 \mathrm{mmol}$ ) gave $32 \mathrm{mg}$ (quant) of 28 as an amorphous white solid. ${ }^{1} \mathrm{H}$ NMR (400 MHz, DMSO- $\left.d_{6}\right) \delta: 11.32$ (s, 4H, NH-1 $\left.{ }^{\mathrm{T} T r p}\right), 8.24-8.17$ (m, 8H, NHCO and Ar), 7.92 (t, $J=8.5 \mathrm{~Hz}, 8 \mathrm{H}, \mathrm{Ar}), 7.67$ (d, $J=8.0 \mathrm{~Hz}, 4 \mathrm{H}, \mathrm{Ar}), 7.58$ (t, $J=7.7 \mathrm{~Hz}, 4 \mathrm{H}, \mathrm{Ar}), 7.34$ (d, $J=8.0$ $\mathrm{Hz}, 4 \mathrm{H}, \mathrm{Ar}), 7.09$ (t, $J=7.5 \mathrm{~Hz}, 4 \mathrm{H}, \mathrm{Ar}), 6.99$ (t, $J=7.5 \mathrm{~Hz}, 4 \mathrm{H}, \mathrm{Ar}), 4.63-4.55$ (m, 4H, $\alpha-$ CHTrp), 3.42-3.24 (m, $12 \mathrm{H}, \mathrm{OCH}_{2}$ and $\left.\beta-\mathrm{CH}_{2} \mathrm{Trp}\right), 3.15$ (dd, $\left.J=14.2,7.1 \mathrm{~Hz}, 4 \mathrm{H}, \beta-\mathrm{CH}_{2} \operatorname{Trp}\right)$, 3.07 (bs, 8H, $\left.\mathrm{OCH}_{2}\right), 2.28-2.06\left(\mathrm{~m}, 8 \mathrm{H}, \mathrm{CH}_{2}\right) .{ }^{13} \mathrm{C} \mathrm{NMR}\left(100 \mathrm{MHz}, \mathrm{DMSO}-d_{6}\right) \delta: 173.7,170.5$, $167.7,136.5,134.8,133.6,132.6,131.8,129.4,129.3,128.5,122.2,119.5,119.3,111.6,108.55$, 69.2, 67.4, 53.4, 45.2, 36.1, 27.9. HPLC [gradient: A:B, 10-100\% of A in $10 \mathrm{~min}$ ]: $4.846 \mathrm{~min}$. HRMS (ESI-) m/z: Cald for $\mathrm{C}_{89} \mathrm{H}_{84} \mathrm{~N}_{8} \mathrm{O}_{24}$ 1648.5598; found 1648.5609. Anal. Cal. for $\mathrm{C}_{89} \mathrm{H}_{84} \mathrm{~N}_{8} \mathrm{O}_{24}: \mathrm{C}, 64.80 ; \mathrm{H}, 5.13$. Found: C, 64.74; H, 5.01.

Tetramer 29. Following the general procedure for the deprotection of methyl estes, compound 26 (35.7 mg, $0.02 \mathrm{mmol}$ ) gave $33 \mathrm{mg}$ (quant) of $\mathbf{2 9}$ as an amorphous white solid. ${ }^{1} \mathrm{H}$ NMR (400 MHz, DMSO- $\left.d_{6}\right) \delta: 11.32$ (s, 4H, NH-1 $\left.{ }^{\mathrm{i} T r p}\right), 8.25$ (d, $\left.J=8.3 \mathrm{~Hz}, 4 \mathrm{H}, \mathrm{NHCO}\right), 8.03$ (d, $J=8.1$ $\mathrm{Hz}, 8 \mathrm{H}, \mathrm{Ar}), 7.80$ (d, $J=8.1 \mathrm{~Hz}, 8 \mathrm{H}, \mathrm{Ar}), 7.69$ (d, $J=8.0 \mathrm{~Hz}, 4 \mathrm{H}, \mathrm{Ar}), 7.35(\mathrm{~d}, J=8.0 \mathrm{~Hz}, 4 \mathrm{H}$, Ar), $7.11(\mathrm{t}, J=7.5 \mathrm{~Hz}, 4 \mathrm{H}, \mathrm{Ar}), 7.00(\mathrm{t}, J=7.5 \mathrm{~Hz}, 4 \mathrm{H}, \mathrm{Ar}), 4.66-4.59$ (m, 4H, $\alpha$-CHTrp), 3.44-3.22 (m, $12 \mathrm{H}, \mathrm{OCH}_{2}$ and $\left.\beta-\mathrm{CH}_{2} \mathrm{Trp}\right), 3.22-3.14$ (m, $\left.4 \mathrm{H}, \beta-\mathrm{CH}_{2} \mathrm{Trp}\right), 3.03$ (bs, $8 \mathrm{H}, \mathrm{OCH}_{2}$ ), 2.27-2.09 (m, 8H, $\left.\mathrm{CH}_{2}\right) .{ }^{13} \mathrm{C}$ NMR (100 MHz, DMSO- $\left.d_{6}\right) \delta: 173.7,170.6,167.6,137.4,136.65$, 
134.4, 130.1, 129.6, 129.3, 128.2, 122.6, 119.7, 119.4, 111.7, 109.6, 69.2, 67.3, 53.4, 45.2, 36.1, 28.1. HPLC [gradient: A:B, 10-100\% of A in $10 \mathrm{~min}$ ]: $5.235 \mathrm{~min}$. HRMS (ESI-) $\mathrm{m} / \mathrm{z}$ : Cald for $\mathrm{C}_{89} \mathrm{H}_{84} \mathrm{~N}_{8} \mathrm{O}_{24}$ 1648.5598; found 1648.5589. Anal. Cal. for $\mathrm{C}_{89} \mathrm{H}_{84} \mathrm{~N}_{8} \mathrm{O}_{24}$ : C, 64.80; $\mathrm{H}, 5.13$. Found: C, 64.96; H, 4.98.

Tetramer 30. Following the general procedure for the deprotection of methyl esters, compound 27 (31 mg, $0.016 \mathrm{mmol}$ ) gave $28 \mathrm{mg}$ (quant) of $\mathbf{3 0}$ as an amorphous white solid. ${ }^{1} \mathrm{H}$ NMR (500 MHz, DMSO- $\left.d_{6}\right) \delta: 11.40$ (s, 4H, NH-1 Trp), 8.44-8.42 (m, 4H, Ar), 8.37-8.34 (m, 8H, Ar), $8.15(\mathrm{~d}, J=8.0 \mathrm{~Hz}, 4 \mathrm{H}, \mathrm{NHCO}), 7.64$ (d, $J=7.9 \mathrm{~Hz}, 4 \mathrm{H}, \mathrm{Ar}), 7.33(\mathrm{~d}, J=8.1 \mathrm{~Hz}, 4 \mathrm{H}$, Ar), 7.11-7.06 (m, 4H, Ar), 6.01-6.95 (m, 4H, Ar), 4.55-4.48 (m, 4H, $\alpha$-CHTrp), 3.39-3.23 (m, $12 \mathrm{H}, \mathrm{OCH}_{2}$ and $\left.\beta-\mathrm{CH}_{2} \mathrm{Trp}\right), 3.15\left(\mathrm{dd}, J=14.4,6.9 \mathrm{~Hz}, 4 \mathrm{H}, \beta-\mathrm{CH}_{2} \mathrm{Trp}\right), 3.09-3.02(\mathrm{~m}, 8 \mathrm{H}$, $\left.\mathrm{OCH}_{2}\right), 2.19\left(\mathrm{dt}, J=14.1,6.8 \mathrm{~Hz}, 4 \mathrm{H}, \mathrm{CH}_{2}\right), 2.10\left(\mathrm{dt}, J=14.0,6.5 \mathrm{~Hz}, 4 \mathrm{H}, \mathrm{CH}_{2}\right) .{ }^{13} \mathrm{C}$ NMR $(126$ MHz, DMSO-d $\left.d_{6}\right) \delta: 173.4,170.4,167.0,136.6,134.2,134.0,133.0,132.4,129.1,129.0,122.4$, 119.6, 119.4, 111.7, 108.9, 69.3, 67.4, 53.2, 45.2, 36.0, 27.6. HPLC [gradient: A:B, 10-100\% of A in $10 \mathrm{~min}$ ]: $3.756 \mathrm{~min}$. HRMS (ESI-) m/z: Cald for $\mathrm{C}_{93} \mathrm{H}_{84} \mathrm{~N}_{8} \mathrm{O}_{32}$ 1824.5192; found 1824.5198 . Anal. Cal. for $\mathrm{C}_{93} \mathrm{H}_{84} \mathrm{~N}_{8} \mathrm{O}_{32}$ : C, 61.18; H, 4.64. Found: $\mathrm{C}, 60.96 ; \mathrm{H}, 4.44$.

General procedure for the synthesis of $\mathbf{N 1}$ benzyl derivatives $31-33$ and 37 . To a solution containing the corresponding trimer $\mathbf{4}$ or tetramer $\mathbf{2 4}(1.0 \mathrm{mmol})$ in acetonitrile anhydrous (10 $\mathrm{mL}), \mathrm{Cs}_{2} \mathrm{CO}_{3}(1.5$ eq for each $\operatorname{Trp})$ was added and the mixture was stirred at room temperature for 15 minutes. Then the corresponding benzyl bromide (1.2 eq for each Trp) was added and the reaction mixture was stirred at $80{ }^{\circ} \mathrm{C}$ for $6 \mathrm{~h}$. The mixture was evaporated to dryness, dissolved in dichloromethane $(20 \mathrm{~mL})$ and washed successively with citric acid $(3 \times 20 \mathrm{~mL})$ and brine $(3 \mathrm{x}$ $20 \mathrm{~mL}$ ). The organic phase was dried over anhydrous $\mathrm{Na}_{2} \mathrm{SO}_{4}$ and evaporated to dryness. The 
residue was purified on a Biotage HPFC (High Performance Flash Chromatography) purification system on reverse phase using water/acetonitrile (100:0 to 0:100) as eluent.

Trimer 31. Following the general procedure, compound 4 (200 mg, $0.23 \mathrm{mmol}), \mathrm{Cs}_{2} \mathrm{CO}_{3}$ (335.6 $\mathrm{mg}, 1.03 \mathrm{mmol}$ ) and benzyl bromide (118.9 $\mu \mathrm{L}, 1.03 \mathrm{mmol})$ afforded $87.2 \mathrm{mg}(33 \%)$ of 31 as an amorphous solid of cream color. ${ }^{1} \mathrm{H}$ NMR (400 MHz, $\left.\mathrm{CDCl}_{3}\right) \delta: 7.52-7.47$ (m, 3H, Ar), 7.30-7.20 (m, 12H, Ar), 7.15-7.04 (m, 12H, Ar), 6.90 (d, J=2.7 Hz, 3H, Ar), 6.13-6.08 (m, 3H, NHCO), 5.25 (bs, 6H, $\mathrm{CH}_{2} \mathrm{Bn}$ ), 4.90-4.83 (m, 3H, $\alpha$-CHTrp), 3.36-3.19 (m, 6H, $\left.\beta-\mathrm{CH}_{2} \operatorname{Trp}\right)$, 2.14-1.90 (m, 12H, $\left.\mathrm{CH}_{2}\right)$. HPLC [gradient: A:B, 10-100\% of A in $10 \mathrm{~min}$ ]: $7.566 \mathrm{~min}$. HRMS $\left(\mathrm{ESI}^{+}\right) \mathrm{m} / \mathrm{z}$ : calculated for $\mathrm{C}_{67} \mathrm{H}_{69} \mathrm{~N}_{7} \mathrm{O}_{11} 1147.4586$; found 1147.4581 .

Trimer 32. Following the general procedure, compound 4 (200 mg, $0.23 \mathrm{mmol}), \mathrm{Cs}_{2} \mathrm{CO}_{3}$ (335.6 mg, $1.03 \mathrm{mmol}$ ) and 4-fluorobenzyl bromide (127.7 $\mu \mathrm{L}, 1.03 \mathrm{mmol})$ afforded $116.1 \mathrm{mg}$ $(42 \%)$ of 32 as an amorphous solid of cream color. ${ }^{1} \mathrm{H}$ NMR $\left(400 \mathrm{MHz}, \mathrm{CDCl}_{3}\right) \delta: 7.41-7.57(\mathrm{~m}$, 3H, Ar), 7.23-7.17 (m, 3H, Ar), 7.16-7.05 (m, 6H, Ar), 7.05-6.98 (m, 6H, Ar), 6.99-6.91 (m, 6H, Ar), 6.89 (bs, 3H, Ar), 6.22-6.09 (m, 3H, NHCO), 5.21 (s, 6H, $\left.\mathrm{CH}_{2} \mathrm{Bn}\right), 4.91-4.80$ (m, 3H, $\alpha$-CHTrp), 3.32-3.15 (m, 6H, $\beta$ - $\left.\mathrm{CH}_{2} \mathrm{Trp}\right), 2.16-1.90\left(\mathrm{~m}, 12 \mathrm{H}, \mathrm{CH}_{2}\right)$. HPLC [gradient: A:B, 10$100 \%$ of $\mathrm{A}$ in $10 \mathrm{~min}$ ]: $8.517 \mathrm{~min}$. HRMS $\left(\mathrm{ESI}^{+}\right) \mathrm{m} / \mathrm{z}$ : calculated for $\mathrm{C}_{67} \mathrm{H}_{66} \mathrm{~F}_{3} \mathrm{~N}_{7} \mathrm{O}_{11} 1201.4586$; found 1201.4582 .

Trimer 33. Following the general procedure, compound 4 (200 mg, $0.23 \mathrm{mmol}), \mathrm{Cs}_{2} \mathrm{CO}_{3}$ (335.6 mg, $1.03 \mathrm{mmol}$ ) and methyl 4-(bromomethyl)benzoate (235.03 mg, $1.03 \mathrm{mmol}$ ) afforded $99.8 \mathrm{mg}(33 \%)$ of $\mathbf{3 3}$ as an amorphous solid of cream color. ${ }^{1} \mathrm{H}$ NMR $\left(400 \mathrm{MHz}, \mathrm{CDCl}_{3}\right) \delta$ : 7.95-7.88 (m, 6H, Ar), 7.52-7.47 (m, 3H, Ar), 7.16-7.04 (m, 15H, Ar), 6.93-6.91 (m, 3H, Ar), 6.25-6.21 (m, 3H, NHCO), 5.29 (bs, 6H, $\left.\mathrm{CH}_{2} \mathrm{Bn}\right), 4.89-4.82$ (m, 3H, $\left.\alpha-\mathrm{CHTrp}\right), 3.33-3.17$ (m, 
$\left.6 \mathrm{H}, \beta-\mathrm{CH}_{2} \mathrm{Trp}\right), 2.13-1.90\left(\mathrm{~m}, 12 \mathrm{H}, \mathrm{CH}_{2}\right)$. HPLC [gradient: $\mathrm{A}: \mathrm{B}, 10-100 \%$ of $\mathrm{A}$ in $10 \mathrm{~min}$ ]: 7.619 min. HRMS (ESI $\left.{ }^{+}\right) \mathrm{m} / \mathrm{z}$ : calculated for $\mathrm{C}_{73} \mathrm{H}_{75} \mathrm{~N}_{7} \mathrm{O}_{17}$ 1321. 4280; found 1321. 4278 .

Tetramer 37. Following the general procedure for the synthesis of N1 benzyl derivatives, compound 24 (200 mg, $0.163 \mathrm{mmol}), \mathrm{Cs}_{2} \mathrm{CO}_{3}(318.9 \mathrm{mg}, 0.98 \mathrm{mmol})$ and methyl 4(bromomethyl)benzoate (224.3 $\mathrm{mg}, 0.98 \mathrm{mmol}$ ) afforded $91.9 \mathrm{mg}(31 \%)$ of 37 as an amorphous solid of cream color. ${ }^{1} \mathrm{H}$ NMR (300 MHz, $\left.\mathrm{CDCl}_{3}\right) \delta: 7.96$ (d, $\left.J=8.5 \mathrm{~Hz}, 8 \mathrm{H}, \mathrm{Ar}\right), 7.58$ (d, $J=7.1$ $\mathrm{Hz}, 4 \mathrm{H}, \mathrm{Ar}), 7.01-7.24$ (m, 20H, Ar), 6.95 (s, 4H, Ar), 6.95-6.845 (m, 4H, NHCO), 5.30 (s, 8H, $\left.\mathrm{CH}_{2} \mathrm{Bn}\right), 4.97$ (m, 4H, $\left.\alpha-\mathrm{CHTrp}\right), 3.90\left(\mathrm{~s}, 12 \mathrm{H}, \mathrm{OCH}_{3}\right), 3.59\left(\mathrm{~s}, 12 \mathrm{H}, \mathrm{OCH}_{3}\right), 3.52-3.40(\mathrm{~m}, 12 \mathrm{H}$, $\left.\mathrm{OCH}_{2}, \beta-\mathrm{CH}_{2} \mathrm{Trp}\right), 3.33-3.24$ (m, 4H, $\left.\beta-\mathrm{CH}_{2} \mathrm{Trp}\right), 3.20-3.09\left(\mathrm{~m}, 8 \mathrm{H}, \mathrm{OCH}_{2}\right), 2.42-2.30(\mathrm{~m}, 8 \mathrm{H}$, $\mathrm{CH}_{2}$ ). HRMS (ESI $\left.{ }^{+}\right) \mathrm{m} / \mathrm{z}$ : calculated for $\mathrm{C}_{102} \mathrm{H}_{109} \mathrm{~N}_{7} \mathrm{O}_{24} 1815.6215$; found 1815.6207.

Trimer 34. Following the general procedure for the deprotection of methyl esters above mentioned, compound $\mathbf{3 1}(60 \mathrm{mg}, 0.05 \mathrm{mmol})$ gave $57.1 \mathrm{mg}$ (quant) of $\mathbf{3 4}$ as an amorphous white solid. ${ }^{1} \mathrm{H}$ NMR (400 MHz, DMSO- $d_{6}$ ) $\delta: 8.28-8.19$ (m, 3H, NHCO), 7.52 (d, $J=7.8 \mathrm{~Hz}$, 3H, Ar), 7.32 (d, $J=8.1 \mathrm{~Hz}, 3 \mathrm{H}, \mathrm{Ar}), 7.26-7.14$ (m, 12H, Ar), 7.12-7.07 (m, 6H, Ar), 7.03 (t, $J$ $=7.5 \mathrm{~Hz}, 3 \mathrm{H}, \mathrm{Ar}), 6.97$ (t, $J=7.4 \mathrm{~Hz}, 3 \mathrm{H}, \mathrm{Ar}), 5.30\left(\mathrm{bs}, 6 \mathrm{H}, \mathrm{CH}_{2} \mathrm{Bn}\right), 4.50-4.43(\mathrm{~m}, 3 \mathrm{H}, \alpha-$ CHTrp), 3.15 (dd, $\left.J=14.7,5.4 \mathrm{~Hz}, 3 \mathrm{H}, \beta-\mathrm{CH}_{2} \operatorname{Trp}\right), 2.97$ (dd, $J=14.6,8.4 \mathrm{~Hz}, 3 \mathrm{H}, \beta-\mathrm{CH}_{2} \operatorname{Trp}$ ), 2.04-1.87 (m, 12H, $\left.\mathrm{CH}_{2}\right) .{ }^{13} \mathrm{C}$ NMR (100 MHz, DMSO) $\delta: 173.3,170.6,138.3,136.0,128.5$, $127.9,127.5,127.3,126.9,121.3,118.8,118.6,110.1,110.0,93.2,53.1,49.0,30.7,29.3,27.1$. HPLC [gradient: A:B, 10-100\% of A in $10 \mathrm{~min}$ ]: $7.382 \mathrm{~min}$. HRMS (ESI-) m/z: calculated for $\mathrm{C}_{64} \mathrm{H}_{63} \mathrm{~N}_{7} \mathrm{O}_{11}$ 1105.4586; found 1105.4583. Anal. Cal. for $\mathrm{C}_{64} \mathrm{H}_{63} \mathrm{~N}_{7} \mathrm{O}_{11}$ : C, 69.49; $\mathrm{H}, 5.74$. Found: C, 69.66; H, 5.99.

Trimer 35. Following the general procedure for the deprotection of methyl esters above mentioned, compound 32 (113.9 mg, $0.09 \mathrm{mmol}$ ) gave $109.3 \mathrm{mg}$ (quant) of $\mathbf{3 5}$ as an amorphous 
white solid. ${ }^{1} \mathrm{H}$ NMR (400 MHz, DMSO- $\left.d_{6}\right) \delta: 8.27-8.21(\mathrm{~m}, 3 \mathrm{H}, \mathrm{NHCO}), 7.52$ (d, $J=7.8 \mathrm{~Hz}$, 3H, Ar), $7.33(\mathrm{dd}, J=8.2,2.1 \mathrm{~Hz}, 3 \mathrm{H}, \mathrm{Ar}), 7.25$ (s, 3H, Ar), 7.18-7.12 (m, 6H, Ar), 7.10-7.01 (m, 9H, Ar), 6.97 (t, $J=7.4 \mathrm{~Hz}, 3 \mathrm{H}, \mathrm{Ar}), 5.30$ (bs, 6H, $\left.\mathrm{CH}_{2} \mathrm{Bn}\right), 4.49-4.41$ (m, 3H, $\left.\alpha-\mathrm{CHTrp}\right)$, $3.14\left(\mathrm{dd}, J=14.7,5.6 \mathrm{~Hz}, 3 \mathrm{H}, \beta-\mathrm{CH}_{2} \mathrm{Trp}\right), 2.98$ (dd, $\left.J=14.6,8.2 \mathrm{~Hz}, 3 \mathrm{H}, \beta-\mathrm{CH}_{2} \mathrm{Trp}\right), 2.06-1.92$ $\left(\mathrm{m}, 12 \mathrm{H}, \mathrm{CH}_{2}\right) .{ }^{13} \mathrm{C} \mathrm{NMR}(100 \mathrm{MHz}, \mathrm{DMSO}) \delta: 173.3,173.3,170.6,170.6,162.6,160.2,135.8$, $134.5,134.5,129.0,128.9,127.9,127.4,121.3,118.8,118.7,115.4,115.1,110.1,93.3,53.2$, 53.1, 48.2, 30.6, 29.3, 27.1. HPLC [gradient: A:B, 10-100\% of A in $10 \mathrm{~min}$ ]: $7.771 \mathrm{~min}$. HRMS (ESI-) $\mathrm{m} / \mathrm{z}$ : calculated for $\mathrm{C}_{64} \mathrm{H}_{60} \mathrm{~F}_{3} \mathrm{~N}_{7} \mathrm{O}_{11}$ 1159.4303; found 1159.4293. Anal. Cal. for $\mathrm{C}_{64} \mathrm{H}_{60} \mathrm{~F}_{3} \mathrm{~N}_{7} \mathrm{O}_{11}$ : C, 66.26; H, 5.21. Found: C, 66.65; H, 4.87.

Trimer 36. Following the general procedure for the deprotection of methyl esters above mentioned, compound $33(79.2 \mathrm{mg}, 0.06 \mathrm{mmol})$ gave $73.9 \mathrm{mg}$ (quant) of $\mathbf{3 6}$ as an amorphous white solid. ${ }^{1} \mathrm{H}$ NMR (400 MHz, DMSO- $\left.d_{6}\right) \delta: 8.28-8.23(\mathrm{~m}, 3 \mathrm{H}, \mathrm{NHCO}), 7.82(\mathrm{~d}, J=7.9 \mathrm{~Hz}$, 6H, Ar), 7.53 (d, $J=7.7 \mathrm{~Hz}, 3 \mathrm{H}, \mathrm{Ar}), 7.31-7.25$ (m, 6H, Ar), 7.19-7.13 (m, 6H, Ar), 7.06-6.95 (m, 6H, Ar), 5.40 (bs, 6H, $\left.\mathrm{CH}_{2} \mathrm{Bn}\right), 4.49-4.42$ (m, 3H, $\left.\alpha-\mathrm{CHTrp}\right), 3.14$ (dd, $J=14.6,5.9 \mathrm{~Hz}, 3 \mathrm{H}$, $\left.\beta-\mathrm{CH}_{2} \mathrm{Trp}\right), 3.00\left(\mathrm{dd}, J=14.5,7.9 \mathrm{~Hz}, 3 \mathrm{H}, \beta-\mathrm{CH}_{2} \mathrm{Trp}\right), 2.06-1.92\left(\mathrm{~m}, 12 \mathrm{H}, \mathrm{CH}_{2}\right) .{ }^{13} \mathrm{C}$ NMR $(100$ MHz, DMSO) $\delta: 173.3,170.6,167.1,143.4,135.9,129.8,129.6,128.0,127.6,126.9,121.4$, $118.9,118.7,110.2,93.3,53.2,48.7,30.6,29.3,27.2$. HPLC [gradient: A:B, 10-100\% of A in 10 min]: $5.380 \mathrm{~min}$. HRMS (ESI-) m/z: calculated for $\mathrm{C}_{67} \mathrm{H}_{63} \mathrm{~N}_{7} \mathrm{O}_{17}$ 1237.4280; found 1237.4279. Anal. Cal. for $\mathrm{C}_{67} \mathrm{H}_{63} \mathrm{~N}_{7} \mathrm{O}_{17}$ : C, 64.99; H, 5.13. Found: C, 64.62; H, 4.90.

Tetramer 38. Following the general procedure for the deprotection of methyl esters above mentioned, compound $37(74.1 \mathrm{mg}, 0.04 \mathrm{mmol})$ gave $69.5 \mathrm{mg}$ (quant) of $\mathbf{3 8}$ as an amorphous white solid. ${ }^{1} \mathrm{H}$ NMR (300 MHz, DMSO) $\delta: 8.23$ (d, $\left.J=7.3 \mathrm{~Hz}, 4 \mathrm{H}, \mathrm{NH}\right) .7 .80$ (d, $J=7.9 \mathrm{~Hz}$, 8H, Ar), 7.52 (d, $J=7.7 \mathrm{~Hz}, 4 \mathrm{H}, \mathrm{Ar}), 7.27$ (d, $J=8.1 \mathrm{~Hz}, 4 \mathrm{H}, \mathrm{Ar}), 7.23$ (s, 4H, Ar), 7.13 (d, $J=$ 
$7.8 \mathrm{~Hz}, 8 \mathrm{H}, \mathrm{Ar}), 7.05-6.98$ (m, 4H, Ar), 6.94 (t, $J=7.4 \mathrm{~Hz}, 4 \mathrm{H}, \mathrm{Ar}), 5.36$ (s, 8H, $\left.\mathrm{CH}_{2} \mathrm{Bn}\right), 4.51-$ $4.44\left(\mathrm{~m}, 4 \mathrm{H}, \alpha\right.$-CHTrp), 3.41-3.28 (m, 8H, $\left.\mathrm{OCH}_{2}\right), 3.14$ (dd, $\left.J=14.5,5.6 \mathrm{~Hz}, 4 \mathrm{H}, \beta-\mathrm{CH}_{2} \operatorname{Trp}\right)$, $3.07\left(\mathrm{~s}, 8 \mathrm{H}, \mathrm{OCH}_{2}\right), 2.98\left(\mathrm{dd}, J=14.7\right.$ y $\left.8.0 \mathrm{~Hz}, 4 \mathrm{H}, \beta-\mathrm{CH}_{2} \mathrm{Trp}\right), 2.22\left(\mathrm{~m}, 8 \mathrm{H}, \mathrm{CH}_{2}\right) .{ }^{13} \mathrm{C} \mathrm{NMR}$ (100 MHz, DMSO) $\delta: 22.2,28.1,49.3,54.1,67.7,69.6,110.6,111.0,119.4,122.0,127.4,128.1$, 128.6, 130.2, 130.6, 136.5, 143.9, 167.8, 170.7, 174.1. HPLC [gradient: A:B, 2-100\% of A in 15 min]: $3.83 \mathrm{~min}$. HRMS (ESI-) $\mathrm{m} / \mathrm{z}$ : calculated for $\mathrm{C}_{93} \mathrm{H}_{92} \mathrm{~N}_{8} \mathrm{O}_{24}$ 1704.6225; found 1704.6267. Anal. Cal. for $\mathrm{C}_{93} \mathrm{H}_{92} \mathrm{~N}_{8} \mathrm{O}_{24}$ : C, 65.48; H, 5.44. Found: C, 65.79; H,5.83.

\section{Synthesis of 22 and 30 using a convergent synthetic strategy}

\section{Dimethyl 5-[3-[2-[((benzyloxy)carbonyl)amino]-3-methoxy-3-oxopropyl]-1H-indol-2-}

yl]isophthalate (40). $N$-Benzyloxycarbonyl-L-tryptophan benzyl ester (1.00 g, $2.84 \mathrm{mmol}, 1$ equiv), dimethyl 5-iodoisophthalate (1.36 g, $4.26 \mathrm{mmol}, 1.50$ equiv), $\mathrm{Pd}(\mathrm{OAc})_{2}$ (32 mg, 0.14 mmol, 5\% mol), $\operatorname{AgBF}_{4}(1.10 \mathrm{~g}, 5.68 \mathrm{mmol}, 2$ equiv) and TFA (0.22 mL, $2.84 \mathrm{mmol}, 1.00$ equiv) were placed in a microwave reactor vessel in dry DMF $(15 \mathrm{~mL})$. The mixture was heated under microwave irradiation $(250 \mathrm{~W})$ at $90{ }^{\circ} \mathrm{C}$ for $30 \mathrm{~min}$. The resulting suspension was filtered through Whatman ${ }^{\circledR}$ filter paper 42 , and the solvent was removed under vacuum. The residue was dissolved in ethyl acetate $(20 \mathrm{~mL})$ and washed successively with saturated $\mathrm{NaHCO}_{3}(3 \times 20 \mathrm{~mL})$ and brine $(3 \times 20 \mathrm{~mL})$. The organic phase was dried over anhydrous $\mathrm{Na}_{2} \mathrm{SO}_{4}$, filtered and evaporated to dryness. The residue was purified by Biotage HPFC (High Performance Flash Chromatography) system on reverse phase using water/acetonitrile (100:0 to 0:100) to afford compound 40 (1.09 g, 71\%) as an amorphous solid of cream color. ${ }^{1} \mathrm{H}$ NMR $\left(400 \mathrm{MHz}, \mathrm{CDCl}_{3}\right)$ $\delta: 8.62\left(\mathrm{~s}, 1 \mathrm{H}, \mathrm{NH}-1^{\mathrm{i}} \mathrm{Trp}\right), 8.39(\mathrm{~s}, 2 \mathrm{H}, \mathrm{Ar}), 7.63(\mathrm{~d}, J=8.0 \mathrm{~Hz}, 1 \mathrm{H}, \mathrm{Ar}), 7.37$ (d, $J=8.1,1 \mathrm{H}$, Ar), $7.30(\mathrm{~m}, 3 \mathrm{H}, \mathrm{Ar}), 7.22$ (d, $J=7.1 \mathrm{~Hz}, 3 \mathrm{H}), 7.13(\mathrm{t}, J=7.4 \mathrm{~Hz}, 1 \mathrm{H}, \operatorname{Ar}), 5.20(\mathrm{~d}, J=8.3 \mathrm{~Hz}$, 1H, NHCO), 4.96 (d, $\left.J=12.2 \mathrm{~Hz}, 1 \mathrm{H}, \mathrm{CH}_{2} \mathrm{Ph}\right), 4.86$ (d, $\left.J=12.2 \mathrm{~Hz}, 1 \mathrm{H}, \mathrm{CH}_{2} \mathrm{Ph}\right), 4.67$ (m, 1H, 
$\alpha$-CHTrp), 3.94 (s, $6 \mathrm{H}, \mathrm{OCH}_{3}$ ), 3.54 (dd, $J=14.8,6.0 \mathrm{~Hz}, 1 \mathrm{H}, \beta$ - $\mathrm{CH}_{2} \mathrm{Trp}$ ), 3.47 (dd, $J=14.8,6.0$ $\left.\mathrm{Hz}, 1 \mathrm{H}, \beta-\mathrm{CH}_{2} \mathrm{Trp}\right), 3.40\left(\mathrm{~s}, 3 \mathrm{H}, \mathrm{OCH}_{3}\right) .{ }^{13} \mathrm{C} \mathrm{NMR}\left(101 \mathrm{MHz}, \mathrm{CDCl}_{3}\right) \delta: 172.1,165.9,155.5$, $136.3,136.2,134.0,133.9,133.2,131.5,129.8,129.1,128.5,128.1,128.0,123.3,120.5,119.4$, 111.3, 108.5, 66.9, 54.6, 52.7, 52.3, 27.7. HPLC [gradient: $\mathrm{H}_{2} \mathrm{O}: \mathrm{MeCN}, 30-100 \%$ of A in 10 $\min ]: 7.805 \mathrm{~min}$.

Dimethyl 5-(3-(2-amino-3-methoxy-3-oxopropyl)-1H-indol-2-yl)isophthalate (41). To a solution of compound 40 (500 mg, $0.92 \mathrm{mmol}, 1.00$ equiv) in DMF (10 mL), ammonium formate (191 mg, 3.03 mmol, 3.30 equiv) and $\mathrm{Pd} / \mathrm{C}(10 \%$ on C; 30 wt.\%) were added. After 3h, The residue was filtrated through a Whatman ${ }^{\circledR}$ filter paper 42 and the solvent was removed under reduced pressure to give $358.5 \mathrm{mg}$ ( $89 \%$ in HPLC) of $\mathbf{4 1}$ as an amorphous white solid. ${ }^{1} \mathrm{H}$ NMR $\left(400 \mathrm{MHz}, \mathrm{CDCl}_{3}\right) \delta: 8.64$ (s, 1H, NH-1 $\left.{ }^{\mathrm{T} T r p}\right), 8.50$ (m, 2H, Ar), 8.45 (s, 1H, Ar), 7.67 (d, $J=7.9$ Hz, 1H, Ar), 7.39 (d, $J=7.9 \mathrm{~Hz}, 1 \mathrm{H}, \mathrm{Ar}), 7.25$ (m, 1H, Ar), 7.16 (t, $J=7.5 \mathrm{~Hz}, 1 \mathrm{H}, \mathrm{Ar}), 3.98$ (s, $\left.6 \mathrm{H}, \mathrm{OCH}_{3}\right), 3.87\left(\mathrm{~m}, 1 \mathrm{H}, \alpha\right.$-CHTrp), $3.59\left(\mathrm{~s}, 3 \mathrm{H}, \mathrm{OCH}_{3}\right), 3.44(\mathrm{dd}, J=14.4,5.1 \mathrm{~Hz}, 1 \mathrm{H}, \beta$ $\mathrm{CH}_{2} \mathrm{Trp}$ ), 3.17 (dd, $\left.J=14.4,5.1 \mathrm{~Hz}, 1 \mathrm{H}, \beta-\mathrm{CH}_{2} \mathrm{Trp}\right), 1.75\left(\mathrm{~s}, 2 \mathrm{H}, \mathrm{NH}_{2}\right) \cdot{ }^{13} \mathrm{C} \mathrm{NMR}(101 \mathrm{MHz}$, $\left.\mathrm{CDCl}_{3}\right) \delta: 175.6,166.1,136.3,133.9,133.8,133.3,131.5,129.7,129.0,123.3,120.3,119.6$ 111.3, 110.2, 55.4, 52.7, 52.1, 30.5. HPLC [gradient: $\mathrm{H}_{2} \mathrm{O}: \mathrm{MeCN}, 5-95 \%$ of A in $10 \mathrm{~min}$ ]: $10.270 \mathrm{~min}$.

Trimers 13 and 22. According to the general coupling procedure, tripodal polyacid $\mathbf{3}$ (100 mg, $0.36 \mathrm{mmol}, 1.00$ equiv), HATU (494 mg, $1.30 \mathrm{mmol}, 3.60$ equiv), intermediate 41 (533 mg, $1.30 \mathrm{mmol}, 3.60$ equiv) and DIPEA (440 $\mu \mathrm{L}, 2.70 \mathrm{mmol}, 7.50$ equiv) afforded trimer 13 (407 $\mathrm{mg}, 85 \%$ ) as an amorphous white solid. Compound 13 (248 mg, $0.12 \mathrm{mmol}, 1.00$ equiv) was treated with $\mathrm{LiOH} / \mathrm{H}_{2} \mathrm{O}$ (232 $\mathrm{mg}, 5.52 \mathrm{mmol}, 18.00$ equiv) as it was previously described, to 
afford $227 \mathrm{mg}$ (quant) of $\mathbf{2 2}$ as an amorphous white solid. Analytical and spectroscopic data of 13 and 22 are consistent with those previously found.

Tetramers 27 and 30. According to the general coupling procedure, tetrapodal polyacid 23 (99 mg, $0.23 \mathrm{mmol}, 1.00$ equiv), HATU (426 mg, $1.12 \mathrm{mmol}, 4.80$ equiv), intermediate 41 (460 mg, 1.12 mmol, 4.80 equiv) and DIPEA (380 $\mu \mathrm{L}, 2.34 \mathrm{mmol}, 10.00$ equiv) afforded tetramer 27 (350 mg, 75\%) as an amorphous white solid. Compound 27 (248 mg, $0.12 \mathrm{mmol}, 1.00$ equiv) was treated with $\mathrm{LiOH} / \mathrm{H}_{2} \mathrm{O}(125 \mathrm{mg}, 2.99 \mathrm{mmol}, 24.00$ equiv) as it was previously described, to afford $227 \mathrm{mg}$ (quant) of $\mathbf{3 0}$ as an amorphous white solid. Analytical and spectroscopic data of $\mathbf{2 7}$ and $\mathbf{3 0}$ are consistent with those previously found.

\section{BIOLOGICAL ASSAYS}

Antiviral activity against HIV. The MT-4 cells used for the anti-HIV assays was a kind gift from Dr. L. Montagnier (formely at the Pasteur Institute, Paris, France) and cultured in RPMI1640 medium (Invitrogen, Merelbeke, Belgium) supplemented with 10\% Fetal Calf Serum (FCS) (Hyclone, Perbio Science, Aalst, Belgium) and 1\% L-glutamine (Invitrogen). The HIV-1 strain NL4-3 was obtained from the AIDS Research and Reference Reagent Program (Division of AIDS, NIAID, NIH) and cultured in MT-4 cells. The virus stock was stored at $-80^{\circ} \mathrm{C}$.

The compounds were evaluated for their inhibitory activity against HIV-1 (NL4.3) and HIV-2 (ROD) infection in MT-4 cell cultures as have been described in detail earlier ${ }^{62}$. Briefly, MT-4 cells $(50 \mu \mathrm{L}, 1 \times 106$ cells $/ \mathrm{mL})$ were pre-incubated for $30 \mathrm{~min}$ at $37^{\circ} \mathrm{C}$ with the test compounds $(100 \mu \mathrm{L})$ in a 96-well plate. Next, the cell-line adapted HIV strains (NL4.3 and ROD) were added according to the TCID50 (50\% Tissue Culture Infectious Dose) of the viral stock. After 5 days, cytopathic effect (CPE) was scored microscopically and the anti-HIV-1 activity (50\% 
effective concentration, EC50) of each compound were calculated using a colorimetric method based in the in situ reduction of 3-(4,5-dimethylthiazol-2-yl)-5-(3-carboxymethoxyphenyl)-2-(4sulfophenyl)-2H-tetrazolium (MTS) ${ }^{63}$ according to the manufacturer's instructions (Promega, Leiden, The Netherlands). Assays are performed by adding a small amount of a solution that contains the tetrazolium compound MTS and an electron coupling reagent (phenazine ethosulfate; PES), directly to culture wells, incubating for 1-4 hours and then recording absorbance at $490 \mathrm{~nm}$ (A490) with a 96-well plate reader. The quantity of formazan product as measured by the amount of $490 \mathrm{~nm}$ absorbance is directly proportional to the number of living cells in culture. Cytotoxicity in MT-4 cells was measured after 5 days using the MTS/PES method $^{62,63}$. Data are the mean \pm S.D. of at least 3 independent experiments.

Time-of-addition (TOA) experiment (HIV). Time-of-addition experiment was adapted from previously reported methods ${ }^{54}$. Briefly, MT-4 cells were infected with HIV-1(IIIB) at an m.o.i. of 0.5. Following a one hour adsorption period, cells were washed, distributed in a 96-well tray at 100,000 cells per well and incubated at $37^{\circ} \mathrm{C}$. Test compounds were added at different times $(0,1,2,3,4,5$ and $6 \mathrm{~h})$ after infection. Product added at time point $0 \mathrm{~h}$, was present during the start of infection and was washed away after 1 hour. After washing, fresh product was added to maintain viral suppression throughout the rest of the experiment. HIV-1 production was determined at $31 \mathrm{~h}$ postinfection via a p24 enzyme-linked immunosorbent assay (Perkin Elmer, Brussels, Belgium). DS5000 was used at $1 \mathrm{mg} / \mathrm{mL}$, AZT at $3.5 \mu \mathrm{M}$, compounds 22 and $\mathbf{3 0}$ at 20 $\mu \mathrm{M}$.

Surface plasmon resonance (SPR) analysis (HIV). It should be noted that the binding of the viral glycoprotein gp120 with the glycosaminoglycans (GAGs) of the host cell initiates HIV infection. To mimic this viral attachment, we used a Surface Plasmon Resonance (SPR) 
approach in which heparin, as mimic of the host cell membrane GAGs, was bound to the sensorchip. ${ }^{55}$ In brief, heparin was biotinylated at the reducing end and captured on a streptavidin sensor chip. Gp120 (10 nM) was injected to measure the full binding capacity of the chip. Next, gp120 (10 nM) was pre-incubated with compound 22 or $\mathbf{3 0}$ and injected over the chip to measure the inhibitory effect of the latter compounds on gp120-heparin interaction.

The experiments were performed at $25^{\circ} \mathrm{C}$ on a Biacore T200 (GE Healthcare, Uppsala, Sweden) in PBS supplemented with 5\% DMSO and 0.005\% (v/v) Tween20 at pH 7.4. Heparin (Iduron) was minimally biotinylated at the reducing end with biotinamidohexanoic acid hydrazide (Sigma-Aldrich). Biotinylated-heparin was extensively dialyzed to remove unreacted biotin and 880 Resonance Units (RU) were captured on a Streptavidin Sensor Chip. Recombinant gp120 HIV-1(III ${ }_{B}$ ) (ImmunoDiagnostics Inc., Woburn, MA) alone (10 nM) or premixed with a concentration range of compound $\mathbf{2 2}$ or $\mathbf{3 0}$ was injected for 2 minutes at a flow rate of $10 \mu \mathrm{l} / \mathrm{min}$. The Sensor chip was immediately regenerated by a single treatment with $1 \mathrm{M}$ $\mathrm{NaCl}$ in $10 \mathrm{mM} \mathrm{NaOH}$. A reference flow was used as a control for non-specific binding and several buffer blanks were used for double referencing.

Antiviral Activity against EV-A71. The EV-A71 BrCr laboratory adapted strain and clinical isolates representative of B genogroup (B2 sub-genogroup: 11316; B5 sub-genogroup: TW/70902/08) and C genogroup (C2 sub-genogroup: H08300 461\#812; C4 subgenogroup: TW/1956/05) were used at a low multiplicity of infection (MOI) in a standardized cell-based antiviral assay. Briefly, rhabdosarcoma (RD) cells were seeded in a 96 well-plate. The day after, a serial dilution of the compounds and the virus inoculum were added to the cells. The assay plates were incubated at $37{ }^{\circ} \mathrm{C}, 5 \% \mathrm{CO}_{2}$ with virus inoculum and compounds until full virusinduced cell death was observed in the untreated, infected controls (3 days post-infection). 
Subsequently, the antiviral effect was quantified using a colorimetric readout with 3-(4,5dimethylthiazol-2-yl)-5-(3-carboxymethoxyphenyl)-2-(4-sulfophenyl)-2H-tetrazolium/phenazine methosulfate (MTS/PMS method) and the concentration of compound at which 50\% inhibition of virus-induced cell death was observed $\left(\mathrm{EC}_{50}\right)$, was calculated from the antiviral dose-response curves. A similar assay setup was used to determine the adverse effect of the compound on uninfected, treated cells for calculation of the $\mathrm{CC}_{50}$ (concentration of compound that reduces overall cell health with $50 \%$ as determined by the MTS/PMS method). Selectivity index (SI) was calculated as the ration of $\mathrm{CC}_{50}$ to $\mathrm{EC}_{50}$.

Time-of-drug-addition experiment (EV-A71). RD cells, grown to confluence in 96-wells assay plates, were treated with compound $22(20 \mu \mathrm{M}$ in $2 \%$ FBS culture medium) at selected time points $1 \mathrm{~h}$ before or at 1,2, $4 \mathrm{~h}$ post-infection with EV-A71, $\mathrm{BrCr}$ (MOI of 1). Virusinfected, untreated cells were used as controls. Pirodavir $(20 \mu \mathrm{M})$, a traditional capsid binder, was included as an entry-inhibitor reference compound. At $8 \mathrm{~h}$ post-infection, intracellular RNA was isolated (RNeasy Mini Kit, QIAGEN) and viral RNA levels were quantified by means of RT-qPCR.

\section{CRYO-ELECTRON MICROSCOPY STUDIES}

Virus purification. EV-A71_11316 was purified as described previously ${ }^{64}$. Briefly, EVA71_11316 was propagated in HeLa cells for $24 \mathrm{~h}$. The media and cells were collected and processed by freezing and thawing three times. Cell debris was pelleted by centrifugation and the supernatant was precipitated with sodium chloride and polyethylene glycol (PEG) 8000. After ultracentrifugation through a $30 \%$ sucrose buffer cushion, the pellets were resuspended and 
applied to a 10 to $35 \% \mathrm{~K}$-tartrate step gradient. The virus was collected and dialyzed against 10 mM Tris, $200 \mathrm{mM} \mathrm{NaCl}, 50 \mathrm{mM} \mathrm{MgCl}$, $\mathrm{pH} 7.5$.

Electron microscopy data collection. EM samples were prepared and data sets were recorded at the Pennsylvania State University - Huck Institutes of the Life Sciences. Prior to incubation and vitrification of the sample, the virus buffer was exchanged to phosphate-buffered saline (PBS). Compounds 22 and $\mathbf{3 0}$ were incubated at $20 \mu \mathrm{M}$ with about $80 \mathrm{nM}$ of the virus at $37^{\circ} \mathrm{C}$ for 1 hour, which equates to about four copies of molecule per each of vertex on the virus capsid. Three microliters of each sample were pipetted onto carbon coated Quantifoil R2/1 grids (Quantifoil Micro Tools GmbH, Jena, Germany), blotted to remove excess, and plunge-frozen in liquid ethane using a Vitrobot (Thermo Fisher, USA). Grids were imaged in a Titan Krios G3 under automated control of the FEI EPU software. An atlas image was assembled from micrographs taken at $165 \mathrm{x}$ magnification on a FEI BM-Ceta camera, and suitable areas were selected for imaging on the FEI Falcon 3EC direct electron detector. The microscope was operated at $300 \mathrm{kV}$ with a $70 \mu \mathrm{m}$ condenser aperture and a $100 \mu \mathrm{m}$ objective aperture. Magnification was set at 59,000x yielding a calibrated pixel size of 1.1 Å. Images were recorded in integration mode saving 59 and 19 fraction images for $\mathbf{2 2}$ and $\mathbf{3 0}$ and the total accumulated exposure was 140 and $58 \mathrm{e}^{-} / \AA^{2}$, respectively (Supporting Information, S1Table).

Image processing. Both data sets (EV-A71_11316-22 and EV-A71_11316-30) were processed in the same manner. Micrograph movie frame stacks were aligned and dose-weighted with the UCSF program MotionCorr v2.165and the contrast transfer function (CTF) of each micrograph was determined with $\mathrm{GCTF}^{66}$. Image processing steps were performed by using RELION v3.167. After initial particle picking for a subset of the data, particles were extracted with a 420-pixel by 420-pixel box and processed for reference-free $2 \mathrm{D}$ classification. Using the 
output 2D classes as references, 51,413 and 84,522 particles were picked by automatic particle picking for $\mathbf{2 2}$ and $\mathbf{3 0}$ data sets, respectively. The extracted particles were subjected to 2D- and 3D-classfiication, yielding 42,926 and 30,452 particles. An ab initio 3D model was generated with icosahedral-symmetry averaging by a stochastic gradient descent algorithm in RELION, followed by $3 \mathrm{D}$ refinement. $3.45 \AA$ and $3.42 \AA$ resolution maps for the virus-alone and the complex $(\mathrm{FSC}=0.143)$ were reconstructed after post-processing. Resolutions improved to 3.03 $\AA$ and $2.89 \AA$ after applying CTF refinement and Bayesian polishing in Relion. In addition to the new complex data, we also reprocessed the recently published EV-A71 data set, which improved the resolution to $3.08^{41}$ (Supporting Information, S1 Table). Specifically, 75,125 particles were selected from 152,476 after 2D and 3D classifications and CTF refinement and Bayesian polishing were applied using the same method as for the two virus-drug complex datasets. Ewald sphere correction was applied to all three maps, resulting in only marginal resolution improvements (Supporting Information, S1 Table).

Atomic coordinate refinement. An atomic model of EV-A71_11316 (PDB ID: 6DIJ) ${ }^{41}$ was used as a starting model. Building of the model into the three sharpened maps was initiated by fitting the starting model as a rigid body in Chimera ${ }^{69}$. The fitted structure of an asymmetric unit was refined with additional rigid_body, morphing, and simulated_annealing options in PHENIX real-space refinement ${ }^{70}$. The refinement asymmetric units were duplicated for sixty icosahedral units and refined with non-crystallographic symmetry using PHENIX real-space refinement ${ }^{70}$. Then, the asymmetric units were refined additionally to optimize the model geometry. The map cross-correlation values with mask for all three models were between 0.81 and 0.83 . Root-meansquare deviation (RMSD) deviations from ideal bonds length and angles were $0.010 \sim 0.011 \AA$ 
and $0.905 \sim 0.920^{\circ}$ for all three models. Ramachandran outliers were $0.00 \%$. The refined model was visually inspected, modified in $\mathrm{COOT}^{71}$, and validated by Molprobity ${ }^{72}$.

Map and structure accession numbers. The cryo-EM density maps for the EV-A71 virus and the two virus-complexes are available at the Electron Microscopy Data Bank via accession codes EMD-20766 (sharpened and unsharpened EV-A71_11316 maps), EMD-20768 (sharpened and unsharpened virus-22 complex maps) and EMD-20769 (sharpened and unsharpened virus-30 complex maps). The atomic coordinates for the viruses built in the two maps are available at the PDB via accession codes 6UH1 (EV-A71_11316), 6UH6 (virus-22 complex) and 6UH7 (virus30 complex).

\section{COMPUTER-ASSISTED MOLECULAR MODELING}

Model building of the constituent fragments of $\mathbf{2 2}$ and $\mathbf{3 0}$ and subsequent assembly into the full dendrimers were accomplished by means of the editing facilities implemented in the molecular graphics program PyMOL ${ }^{73}$ which was also employed for trajectory visualization and 3D figure generation. $A b$ initio geometry optimization and derivation of RESP point charges for the methyl-capped pentaerythritol core and the isophthaloyl-decorated Trp residue were achieved by means of a $6-31 \mathrm{G}^{*}$ basis set and the Hartree-Fock method, as implemented in the Gaussian 09 program. ${ }^{74}$ The standard ff14SB force field parameter set ${ }^{75}$ in AMBER $16^{76}$ was used for both ligand and protein atoms.

A three-dimensional cubic grid consisting of $65 \times 65 \times 65$ points with a spacing of $0.375 \AA$ centered on the VP1 pore region displaying electron density for $\mathbf{3 0}$ was defined for docking purposes. Electrostatic, desolvation, and affinity maps for the atom types present in the decorated Trp fragment of 30 were calculated using AutoGrid 4.2.6; thereafter the Lamarckian genetic 
algorithm implemented in AutoDock $4{ }^{77}$ was used to generate 100 docked conformations of the fragment. Intra- and intermolecular energy evaluation of each configuration allowed the selection of the 10 best scoring solutions for each fragment. Significant clustering of top-ranking solutions at two of the five intermonomer interfaces was apparent and visual inspection confirmed their feasibility in the context of the full molecule. Therefore, the best binding poses were used for model building a complex of the VP1 pentamer with a full dendrimer that had one of its four legs docked in compliance with the previous docking results.

The VP1-30 complex was immersed in a cubic box of TIP3P water molecules and simulated essentially as described before. ${ }^{41}$ In brief, a weak harmonic restraint of $2 \mathrm{kcal} \mathrm{mol}^{-1} \AA^{-2}$ on the protein $\mathrm{C} \alpha$ atoms was used to restrain the protein backbone and every $5 \mathrm{~ns}$ a snapshot from the simulated trajectory was cooled down from 300 to $273 \mathrm{~K}$ over a 1-ns period and energyminimized to provide an ensemble of 30 low-energy structures. The PyMOL implementation of the Adaptive Poisson-Boltzmann Solver (APBS) method $^{78}$ was used to calculate and display the molecular electrostatic potential on the solvent-accessible surface of the VP1 pentamer.

\author{
ASSOCIATED CONTENT \\ Supporting Information \\ ${ }^{1} \mathrm{H}$ and ${ }^{13} \mathrm{C}$ NMR spectra of the most representative compounds (PDF), cryo-EM data \\ collection, refinement and validation statistics for the EV-A71_11316 and EV-A71_11316-22 \\ and EV-A71_11316-30 complexes and computer-assisted molecular modeling details. \\ Molecular formula strings of the novel synthesized compounds are also available (CSV).
}




\section{AUTHOR INFORMATION \\ Corresponding Author}

Phone: 34912587617. Fax:34915644853. E-mail:anarosa@iqm.csic.es

\section{ORCID}

\section{A. San-Félix: 0000-0003-4271-7598}

\section{Present Addresses}

$¥$ Medicinal Chemistry, Rega Institute for Medical Research, KU Leuven, B-3000, Leuven, Belgium.

\& Department of Medicine, The Pennsylvania State University College of Medicine, Hershey, Pennsylvania, USA.

\section{ACKNOWLEDGEMENTS}

This work was supported by the Spanish MINECO [projects SAF2015-64629-C2-1-R and SAF2015-64629-C2-2-R (MINECO/FEDER)], the Spanish "Ministerio de Ciencia, Innovación y Universidades" (project PID2019-104070RB-C21) and by the Spanish Agencia Estatal Consejo Superior de Investigaciones Científicas (CSIC, Projects CSIC201680E079 and 201980E028), "The Centers of Excellence" of the KU Leuven (EF-05/15 and PF-10/18), EU FP7 (FP7/20072013) Project EUVIRNA (Grant 408 Agreement 264286), EU FP7 SILVER (Contract HEALTH-F3-2010-260644), a grant from the Belgian Interuniversity Attraction Poles (IAP) Phase VII-P7/45 (BELVIR) and the EU FP7 Industry-Academia Partnerships and Pathways Project AIROPICO. The Spanish MEC/MINECO is also acknowledged for a grant to B.M.G and the China Scholarship Council (CSC) (Grant 201403250056) for a grant to L.S. We also thank Charlotte Vanderheydt, Sandra Claes and Evelyne Van Kerckhove for helping with the 
processing of the antiviral antiviral data. This work has been awarded with the Janssen prize within the "XVIII call for prizes for young researchers of the Spanish Society of Medicinal Chemistry (SEQT)." S.H. received a grant with the Pennsylvania Department of Health using Tobacco CURE Funds.

\begin{abstract}
ABBREVIATIONS
Trp, tryptophan; HATU, Hexafluorophosphate Azabenzotriazole Tetramethyl Uronium; DIPEA, N,N-diisopropylethylamine; TFA, trifluoroacetic acid; DMF, dimethylformamide; HIV, Human immunodeficiency virus; AIDS, Acquired Immune Deficiency Syndrome; FCS, fetal calf serum; GAGs, glycosaminoglycans; MTS, 3-(4,5-dimethylthiazol-2-yl)-5-(3-carboxymethoxyphenyl)-2(4-sulfophenyl)-2H-tetrazolium; SPR, Surface plasmon resonance; PES, phenazine ethosulfate; EV71, enterovirus 71; EV-A71, enterovirus 71 genogroup A; CCR5, chemokine receptor type 5; DS-5000, dextran sulfate-5000; PRM-A, pradimicin A; cryo-EM, cryo-electron microscopy.
\end{abstract}

$\underline{\text { PDB ID Codes. }}$ Coordinates have been deposited at the Protein Data Bank (PDB) under accession numbers PDB 6UH1 (EV-A71_11316), PDB 6UH6 (EV-A71_11316 + 22) and PDB 6UH7 (EV-A71_11316 + 30). Authors will release the atomic coordinates and experimental data upon article publication. PDB IDs have been provided in Table S1 (Supporting Material, page S31).

\title{
REFERENCES
}

(1) UNAIDS data 2018. http://www.unaids.org/en/topic/data (accessed 22 August 2019).

(2) Arts, E. J.; Hazuda, D. J. HIV-1 antiretroviral drug therapy. Cold Spring Harbor Perspect. Med. 2012, 2, a007161. 
(3) Broder S. The development of antiretroviral therapy and its impact on the HIV-1/AIDS pandemic. Antiviral Res. 2010, 85, 1-18.

(4) De Clercq, E.; Li, G. Approved antiviral drugs over the past 50 years. Clin. Microbiol. Rev. 2016, 29, 695-747.

(5) Mehellou, Y.; De Clercq, E. Twenty-six years of anti-HIV drug discovery: where do we stand and where do we go?. J. Med. Chem. 2010, 53, 521-538.

(6) Volberding, S.; Deeks, G. Antiretroviral therapy and management of HIV infection. Lancet 2010, 376, 9734, 49-62.

(7) Zhan, P; Pannecouque, C.; De Clercq, E.; Liu, X. Anti-HIV drug discovery and development: Current innovations and future trends. J. Med. Chem. 2016, 59, 2849-78.

(8) Drug resistance database. https://hivdb.stanford.edu/dr-summary/resistance-notes/NNRTI/ (accessed December 13, 2018).

(9) Gaardbo, J.C.; Hartling, H.J.; Gerstoft, J.; Nielsen, S.D. Incomplete immune recovery in HIV infection: mechanisms, relevance for clinical care, and possible solutions. Clin. Dev. Immunol. 2012, 670957, 1-17.

(10) Margolis, A.M.; Heverling, H.; Pham, P.A.; Stolbach. A. A Review of the Toxicity of HIV Medications, J. Med. Toxicol. 2014, 10, 26-39.

(11) Rojas, P.; Holguín, A. Drug resistance in the HIV-1-infected paediatric population worldwide: a systematic review. J. Antimicrob. Chemother. 2014, 69, 2032-2042.

(12) WHO. World Health Organization HIV/AIDS fact sheet [Internet]. 2018 https://www.who.int/en/news-room/fact-sheets/detail/hiv-aids (accessed 19 July 2018). 
(13) Barré-Sinoussi, F.; Ross, A. L.; Delfraissy, J.-F. Past, present and future: 30 years of HIV research. Nat. Rev. Microbiol. 2013, 12, 877-883.

(14) Badia, R., Ballana, E., Esté, J.A., Riveira-Muñoz, E. Antiviral treatment strategies based on gene silencing and genome editing, Curr. Opin. Virol, 2017, 24, 46-54.

(15) Kumari, G.; Singh. R.K. Anti-HIV drug development: structural features and limitations of present day drugs and future challenges in the successful HIV/AIDS treatment. Curr. Pharm. Des. 2013, 19, 1767-1783.

(16) Tintori, C.; Brai, A.; Fallacara, A. L.; Fazi, R.; Schenone, S.; Botta. M. Protein-protein interactions and human cellular cofactors as new targets for HIV therapy. Curr. Opin. Pharmacol. 2014, 18, 1-8.

(17) Gulick, R.M., Investigational antiretroviral drugs: what is coming down the pipeline. Top. Antivir. Med. 2019, 25, 127-132.

(18) Esté, J.A. Inhibition of HIV entry. In: Antiviral drug strategies, Methods and principles in Medicinal Chemistry, vol 50; De Clercq, E. (Ed.); Wiley-VCH Verlag GmbH\&Co. KGaA; Weinheim, Germany, 2011; pp 29-50.

(19) Kang, Y.; Guo, J.; Chen, Z. Closing the door to human immunodeficiency virus. Protein Cell 2013, 4, 86-102.

(20) Klase, J. The molecular basis of HIV entry. Cell Microbiol. 2012, 14, 1183-1192.

(21) Lu, L.; Fei, Y.; Lifeng, C.; Asim, K. D.; Shibo, J. Development of small-molecule HIV entry inhibitors specifically targeting gp120 or gp41. Curr. To. Med. Chem. 2016, 16, 10741090.

(22) Micewicz, E.D.; Ruchala, P. Inhibitors of HIV-1 entry. Curr. Pharm. Des., 2013, 10, 17841799. 
(23) Wilen, C.B.; Tilton, J.C.; Doms, R.W. Molecular mechanisms of HIV entry. Adv. Exp. Med. Biol. 2012, 726, 223-242.

(24) Ding, X.; Zhu, Y.; Chong, H.; Cui, S.; Zhang, X.; He, J.; Wang, X.; He, Y. Structural and functional characterization of HIV-1 cell fusion inhibitor T20. AIDS, 2018, 33, 1-11.

(25) Fletcher. C.V. Enfuvirtide, a new drug for HIV infection. Lancet 2003, 361, 1577-1578.

(26) Woollard, S.M.; Kanmogne, G.D., Maraviroc: a review of its use in HIV infection and beyond. Drug. Des. Devel. Ther., 2015, 9, 5447-5468.

(27) Rivero-Buceta, E.; Doyagüez, E.G.; Colomer, I.; Quesada, E.; Mathys, L.; Noppen, S.; Liekens, S.; Camarasa, M-J.; Pérez-Pérez, M-J.; Balzarini. J.; San-Félix, A. Tryptophan dendrimers that inhibit HIV replication, prevent virus entry and bind to the HIV envelope glycoproteins gp120 and gp41. European J. Med Chem 2015, 106, 34-43.

(28) Rivero-Buceta, E.; Sun, L.; Martínez-Gualda, B.; Doyagüez, E.G.; Donkers, K.; Quesada, E.; Camarasa, M-J.; Delang, L.; San-Félix, A.; Neyts, J.; Leyssen. P. Optimization of a class of tryptophan dendrimers that inhibit HIV replication leads to a selective, specific and lownanomolar inhibitor of clinical isolates of enterovirus A71. Antimicrob. Agents and Chemother 2016, 60, 5064-5067.

(29) Nadel, S. Hand, foot, mouth, brainstem and heart disease resulting from enterovirus 71. Crit. Care Med., 2013, 41, 1821-1822.

(30) Solomon, T.; Lewthwaite, P.; Perera, D.; Cardosa, M.J.; McMinn, P.; Ooi, M.H. Virology, epidemiology, pathogenesis and control of enterovirus 71. Lancet Infect.Dis., 2010, 10, 778790.

(31) McMinn, P.C. An overview of the evolution of enterovirus 71 and its clinical and public health significance. FEMS Microbiol Rev. 2002, 26, 91-107. 
(32) Chang, L-Y.; Huang, L-M.; Gau, SS-F.; Wu, Y-Y.; Hsia, S-H.; Fan, T-Y.; Lin, K-L.; Huang, Y-C.; Lu, C-Y.; Lin, T-Y. Neurodevelopment and cognition in children after enterovirus 71 infection. N. Engl. J. Med. 2007, 356, 1226-1234.

(33) Chen, C.Y.; Chang, Y.C.; Huang, C.C.; Lui, C.C.; Lee, K.W.; Huang. S.C. Acute flaccid paralysis in infants and young children with enterovirus 71 infection: MR imaging findings and clinical correlates. AJNR Am. J. Neuroradiol. 2001, 22, 200-205.

(34) Chan, Y-F.; Sam, I-C.; Wee, K-L.; Abubakar, S. Enterovirus 71 in Malaysia: A decade later. Neurol Asia, 2011, 16, 1-15.

$$
\text { ProMED-mail post Human enterovirus } 2016 \text { Spain: }
$$
http://promedmail.org/post/20160524.4242904 for earlier report on this enterovirus outbreak in Catalonia, Spain.

(36) ECDC [European Centre for Disease Prevention and Control] Week 31, 29 July-4 August 2018 https://ecdc.europa.eu/en/search?s=enterovirus+A71

(37) Tan, Y.W.; Chu, J.J.H. Sinovac EV71 vaccine: the silver bullet for hand,foot and mouth disease-or not? J. Public Heal Emerg. 2017; 1. doi: 10.21037/jphe.2016.12.14.

(38) Li, J.X.; Song, Y.F.; Wang, L.; Zhang, XF, Hu YS, Hu, YM, Xia, JL, Li, J, Zhu, FC, Twoyear efficacy and immunogenicity of Sinovac Enterovirus 71 vaccine agasint hand, foot and mouth disease in children, Expert Rev, Vaccines 2016, 15, 129-137.

(39) Ng, Q.; He, F.; Kwang, J. Recent progress towards novel EV71 anti-therapeutics and vaccines. Viruses 2015, 7, 6441-6457. 
(40) Baggen, J.; Thibaut, H.J.; Strating J.R.P.M., van Kuppeveld, F.J.M.. The life cycle of nonpolio enteroviruses and how to target it. Nat. Rev. Microbiol. 2018, 16, 368-381.

(41) Sun, L.; Lee, H.; Thibaut, H.J; Rivero-Buceta, E.; Bator, C.; Martinez-Gualda, B. ; Dallmeiera, K.; Leen Delang, L.; Leyssen, P.; Gago, F.; San-Félix A.; Hafenstein, S.; Mirabelli, C.; Neyts J., 2019. Viral engagement with host (co-)receptors blocked by a novel class of tryptophan dendrimers that targets the 5-fold-axis of the enterovirus-A71 capsid. PLOS Pathog. 15(5), e1007760.htps//doi.org/10.1371/journal.ppat/1007760.

(42) Martínez-Gualda,B.; Sun, L.; Rivero-Buceta, E.; Flores, A.; Quesada, E.; Balzarini, J.; Noppen, S.; Liekens, S.; Schols, D.; Neyts, J.; Leyssen, P.; Mirabelli, C.; Camarasa, M.J.; San-Félix, A. Structure-activity relationship studies on a Trp dendrimer with dual activities against HIV and enterovirus A71. Modifications on the amino acid. Antivir. Res. 2017, 139, $32-40$.

(43) Martínez-Gualda,B.; Sun, L.; Martí-Marí, O.; Mirabelli, C.; Delang, L.; Neyts, J.; Schols, D.; Camarasa, M.-J., San-Félix, A. Modifications in the branched arms of a class of dual inhibitors of HIV and EV71 replication expand their antiviral spectrum. Antivir. Res. 2019, $210-214$.

(44) Cachi, S.; Fabrizi, G. Synthesis and functionalization of indoles through palladiumcatalyzed reactions. Chem. Rev. 2005, 2873-2920.

(45) Ruiz-Rodríguez, J.; Albericio, F.; Lavilla, R. Post-synthetic modification of peptides: chemoselective C-arylation of tryptophan residues. Chem. Eur. J. 2010, 16, 1124-1127.

(46) Preciado, S.; Mendive-Tapia, L.; Albericio, F.; Lavilla, R. Synthesis of C-2 arylated tryptophan amino acids and related compounds through palladium-catalyzed $\mathrm{C}-\mathrm{H}$ activation. J. Org. Chem., 2013, 78, 8129-8135. 
(47) Ornelas, C.; Broichhagen, J.; Weck, M. Strain-promoted alkyne azide cycloaddition for the functionalization of poly(amide)-based dendrons and dendrimers. J. Am. Chem. Soc., 2010, $132,3923-3931$.

(48) Flores, A.; Camarasa, M.J.; Pérez-Pérez, M.J.; San-Félix, A.; Balzarini, J.; Quesada, E. Multivalent agents containing 1-substituted 2,3,4-trihydroxyphenyl moieties as novel synthetic polyphenols directed against HIV-1. Org. Biomol. Chem. 2014, 12, 5278-5294.

(49) Newkome, G.R.; Weis, C.D. 6,6-bis(carboxy-2-oxabutyl)-4,8-dioxaundecane-1,11dicarboxylic acid. Org. Prep. Proced. Int., 1996, 28, 242-244.

(50) Gowda, D.Ch.; Rajesh, B.; Gowda, S. Ammonium formate catalytic transfer hydrogenation: a convenient method for removal of halogenated benzyloxycarbonyl and benzyl protecting groupd in peptide synthesis, Indian Journal of Chemistry, 2000, 39B, 504-508.

(51) Baba, M.; Pauwels, R.; Balzarini, J.; Arnout, J.; Desmyter, J.; De Clercq, E. Mechanism of inhibitory effect of dextran sulfate and heparin on replication of human immunodeficiency virus in vitro. Proc. Natl. Acad. Sci. 1988, 85, 6132-6136.

(52) Balzarini, J.; Laethem, K.V.; Daelemans, D.; Hatse, S.; Bugatti, A.; Rusnati, M.; Igarashi, Y.; Oki, T.; Schols, D. Pradimicin A, a carbohydrate-binding nonpeptidic lead compound for treatment of infections with viruses with highly glycosylated envelopes, such as human Immunodeficiency virus, J. Virol. 2007, 81, 362-373.

(53) Pauwels, R.; Andries, K.; Desmyter, J.; Schols, D.; Kukla, M. J.; Breslin, H. J.; Raeymaeckers, A.; Van Gelder, J.; Woestenborghs, R.; Heykants, J.; Schellekens, K.; 
Janssen, M. A. C.; De Clercq, E. and Janssen, P.A.J. Potent and selective inhibition of HIV-1 replication in vitro by a novel series of TIBO derivatives. Nature 1990, 343, 470-474.

(54) Daelemans, D.; Pauwels, R.; De Clercq, E. and Pannecouque, C. A time-of-drug addition approach to target identification of antiviral compounds. Nat. Protoc. 2011, 6, 925-933.

(55) Nici, F; Oliviero, G.; Falanga, A.P.; D’Errico, S.; Marzano, M.; Musumeci, D.; Montesarchio, D.; Noppen, S.; Pannecouque, C.; Piccialli, G.; Borbone, N. Org. Biomol. Chem. 2018, 16, 2349-2355.

(56) Tijsma, A.; Franco, D.; Tucker, S.; Hilgenfeld, R.; Froeyen, M.; Leyssen, P.; Neyts, J. The capsid binder vapendavir and the novel protease inhibitor SG85 inhibit enterovirus 71 replication. Antimicrob. Agents Chemother. 2014, 58, 6990-6992. http://dx.dou.org/10.1128/AAC.03328-14.

(57) Andries, K.; Dewindt, B.; Snoeks, J.; Willebrords, R.; Van Eemeren, K.; Stokbroekx, R.; Janssen, P.A.J. In vitro activity of pirodavir (R 77975), a substituted phenoxy pyridazinamine with broad-spectrum antipicornaviral activity. Antimicrob Agents Chemother, 1992, 36, 100107.

(58) Yamayoshi, S.; Yamashita, Y.; Li, J.; Hanagata, N.; Minowa, T.; Takemura, T.; Koike, S. Scavenger receptor B2 is a celular receptor for enterovirus 2009, Nat. Med. 15, 798-801.

(59) Thibaut, H.J.; Leyssen, P.; Puerstinger, G.; Muigg, A.; Neyts, J.; De Palma, A.M. Towards the design of combination therapy for the treatment of enterovirus infections. Antiviral Res. 2011, 90, 213-217. http://dx.doi.org/10.1016/j.antiviral.2011.03.187. 
(60) Plevka, P; Perera, R.; Cardosa, J.; Kuhn, R.J.; Rossman, M.G. Crystal structure of human enterovirus 71, Science 2012, 336, 1274.

(61) Plevka, P; Perera, R.; Cardosa, J.; Kuhn, R.J.; Rossman, M.G. Structure determination of enterovirus 71. Acta Cryst. 2012, 1217-1222.

(62) Vermeire, K.; Princen, K.; Hatse, S.; De Clercq, E.; Dey. K; Bell; T.W.; Schols, D. CADA, a novel CD4-targeted HIV inhibitor, is synergistic with various anti-HIV drugs in vitro. AIDS 2004, 18, 2115-2125.

(63) Pauwels, R.; Balzarini, J.; Baba, M.; Snoeck, R.; Schols, D.; Herdewijn, P.;Desmyter, J.; De Clercq, E. Rapid and automated tetrazolium-based colorimetric assay for the detection of antiHIV compounds. J. Virol. Meth., 1988, 20, 309-321.

(64) Shingler, K. L.; Organtini, L. J.; Hafenstein, S. Enterovirus 71 Virus Propagation and Purification. Bio-protocol 2014, 4, 9, DOI: 10.21769/BioProtoc.1117.

(65) Zheng, S. Q.; Palovcak, E.; Armache, J.P.; Verba, K.A.; Cheng, Y.; Agard, D.A. MotionCor2: anisotropic correction of beam-induced motion for improved cryo-electron microscopy. Nat. Methods 2017, 14, 331-332.

(66) Zhang, K. Gctf: Real-time CTF determination and correction. J. Struct. Biol. 2016, 193, 112.

(67) Zivanov, J.; Nakane T.; Forsberg B.O.; Kimanius D.; Hagen W.J.H.; Lindahl E.; Scheres S.H.W. New tools for automated high-resolution cryo-EM structure determination in RELION-3. eLife 2018, 7:e42166 DOI: 10.7554/eLife.42166. 
(68) Scheres, S. H. W. Semi-automated selection of cryo-EM particles in RELION-1.3. J. Struct. Biol. 2015, 189, 114-122.

(69) Pettersen, E. F.; Goddard, T.D.; Huang, C.C.; Couch, G.S.; Greenblatt, D.M.; Meng, E.C.; Ferrin, T.E. UCSF Chimera-A visualization system for exploratory research and analysis. J. Comput.Chem. 2004, 25, 1605-1612.

(70) Afonine, P.V.; Headd, J.J.; Terwilliger, T. C.; Adams, P. D. PHENIX News. Computational Crystallography Newsletter 2013, 4, 43-44.

(71) Emsley, P.; Lohkamp, B.; Scott, W. G.; Cowtan, K. Features and development of Coot. Acta Crystallogr. D Biol. Crystallogr. 2010, 66, 486-501.

(72) Chen, V.B.; Arendall W.B.3 ${ }^{\text {rd }}$; Headd J.J.; Keedy, D.A. Immormino, R.M.; Kaprai G.J.; Murray, L.W.; Richarson, J.S.; Richardson D.C. MolProbity: all-atom structure validation for macromolecular crystallography. Acta Crystallogr. D Biol. Crystallogr. 2010, 66, 12-21.

(73) DeLano, W. L. The PyMOL Molecular Graphics System, 1.3; Schrödinger, LLC.: 2013.

(74) Frisch MJ, Trucks GW, Schlegel HB, Scuseria GE, Robb MA, Cheeseman JR, Scalmani G, Barone V, Mennucci B, Petersson GA, Nakatsuji H, Caricato M, Li X, Hratchian HP, Izmaylov AF, Bloino J, Zheng G, Sonnenberg JL, Hada M, Ehara M, Toyota K, Fukuda R, Hasegawa J, Ishida M, Nakajima T, Honda Y, Kitao O, Nakai H, Vreven T, Montgomery JA Jr, Peralta JE, Ogliaro F, Bearpark MJ, Heyd J, Brothers EN, Kudin KN, Staroverov VN, Kobayashi R, Normand J, Raghavachari K, Rendell AP, Burant JC, Iyengar SS, Tomasi J, Cossi M, Rega N, Millam NJ, Klene M, Knox JE, Cross JB, Bakken V, Adamo C, Jaramillo J, Gomperts R, Stratmann RE, Yazyev O, Austin AJ, Cammi R, Pomelli C, Ochterski JW, Martin RL, Morokuma K, Zakrzewski VG, Voth GA, Salvador P, Dannenberg JJ, Dapprich 
S, Daniels AD, Farkas Ö, Foresman JB, Ortiz JV, Cioslowski J, Fox DJ (2009) Gaussian 09, Gaussian, Inc., Wallingford

(75) Maier, J. A.; Martinez, C.; Kasavajhala, K.; Wickstrom, L.; Hauser, K. E.; Simmerling, C., ff14SB: Improving the accuracy of protein side chain and backbone parameters from ff99SB. J Chem Theory Comput 2015, 11 (8), 3696-713.

(76) Kaus, J. W.; Pierce, L. T.; Walker, R. C.; McCammon, J. A., Improving the efficiency of free energy calculations in the AMBER molecular dynamics package. $J$ Chem Theory Comput 2013, 9 (9).

(77) Morris, G. M.; Huey, R.; Lindstrom, W.; Sanner, M. F.; Belew, R. K.; Goodsell, D. S.; Olson, A. J., AutoDock4 and AutoDockTools4: Automated docking with selective receptor flexibility. J. Comput. Chem. 2009, 30, 2785-2791.

(78) Baker, N. A.; Sept, D.; Joseph, S.; Holst, M. J.; McCammon, J. A., Electrostatics of nanosystems: application to microtubules and the ribosome. Proc Natl Acad Sci U S A 2001, 98, 10037-10041.

\section{LIST OF CAPTIONS}

Figure 1. Structures of the prototype pentaerythritol derivative MADAL-385 (1) and "truncated" analogues I and II.

Figure 2. Results of the time-of-drug-addition experiment for compounds 22 and $\mathbf{3 0} . \mathrm{CD}^{+} \mathrm{T}$ cells were treated with the compounds at selected times before, during or after infection with HIV-1. 8h post-infection, cells were harvested and $\mathrm{p} 24$ was isolated and quantified by means of RT-qPCR. Data for AZT are given as reference.

Figure 3. Inhibition of gp120-heparin binding by 22 and $\mathbf{3 0}$ as measured by SPR. Biotinylated heparin was captured on a Streptavidin Sensor Chip. Gp120 (10 nM) was mixed with a concentration range of compound 22 (A) or 30 (B). One representative sensorgram per compound out of three independent experiments is shown. Binding levels (RU) were converted 
into percentage inhibition relative to gp120 binding without compound. Mean (+SEM) and nonlinear fit of three independent experiments are shown (C).

Figure 4. Time-of-drug-addition for compound 22. RD cells were treated with the compounds at selected times before, during or after infection with EV-A71. 8h post-infection, cells were harvested and intracellular viral RNA was isolated and quantified by means of RT-qPCR.

Figure 5. Cryo-EM 3D maps identified the MADAL drugs on the capsid 5-fold vertex. (A) Surface rendering of the sharpened 3D maps for EV-A71 incubated with 22 (left) and 30 (right) showed canonical features of the capsid. Icosahedral symmetry axes were marked with arrows. (B) Comparison of the unsharpened maps (gray) of $\mathbf{2 2}$ and $\mathbf{3 0}$ complexes with EV-A71 showed extra densities (yellow) on the 5-fold axis. The surface rendered at $1 \sigma$ and $1.9 \sigma$ (insets) for EVA71 (left), 22 (middle) and 30 (right). (C) Central sections of the three cryo-EM maps showed extra densities on the 5-fold-vertex covering the hole at the symmetry axis. Icosahedral symmetry axes were marked.

Figure 6. Atomic model built into the cryo-EM map. (A) The atomic models for EV-A71 VP1 (blue), VP2 (green), VP3 (red), VP4 (yellow), and the pocket factor (orange) were built into the cryo-EM map of the virus-30 complex (gray mesh). (B) Representative residues of each VP and the pocket-factor are shown within the corresponding cryo-EM density envelopes to illustrate the quality of the 3D map.

Figure 7. The drug densities are connected to two VP1 residues. (A) The icosahedrally averaged drug density (yellow, 30) was connected mostly with Lys244 and Tyr245 on the VP1 surface (grey). The atomic model of VP1 is depicted as a blue ribbon and the side-chains are shown as sticks. The surface is rendered at $1.9 \sigma$. Neighboring residues are also labeled. (B) Sideview of the interaction site shows the thin drug density connected to the two VP1 residues. (C) Binding pose proposed by the automated docking program for the substituted Trp residue in $\mathbf{3 0}$ at the interface between chains $\mathrm{E}$ (cyan) and Q (pink).

Figure 8. Proposed binding mode of the decorated Trp moiety of 30 around the 5-fold axis of the EV-A71 capsid. (A) A semitransparent surface envelops the five VP1 chains making up the pore. $\mathrm{C}$ atoms in chains $\mathrm{A}, \mathrm{E}, \mathrm{I}, \mathrm{M}$, and Q are colored in green, cyan, magenta, yellow and pink, respectively. Note that the ethylene linker points towards the central pore. (B) Solventaccessible surface of the VP1 pentamer color-coded according to the molecular electrostatic potential calculated with APBS (red, $-3.0 \mathrm{kT} / \mathrm{e}$; blue, $+3.0 \mathrm{kT} / \mathrm{e}$ ). The yellow surface filling the subunit interfaces corresponds to the van der Waals surface of the five docked fragments shown in (A).

Scheme 1. Synthesis of the tripodal derivatives I and 14-22.

Scheme 2. Synthesis of the tetrapodal derivatives II and 28-30. 
Scheme 3. Synthesis of the N1 substituted tripodal (34-36) and tetrapodal (38) derivatives.

Scheme 4. Alternative synthetic route for the synthesis of 22 and $\mathbf{3 0 .}$

Table 1. Anti-HIV-1 and anti-HIV-2 activity of the selected group of compounds

Table 2. Antiviral activity of dendrimers against the $\mathrm{BrCr}$ lab strain of EV-A71 virus in RD cells.

Table 3. Evaluation of the broad-spectrum antiviral effect of compounds 22, 28 and $\mathbf{3 0}$ against a representative panel of clinical EV71 isolates in RD cells.

Table 4. Susceptibility of reverse-engineered EV-A71 variants to prototype 1 and compounds 22 and 30

\section{TABLE OF CONTENTS GRAPHIC}

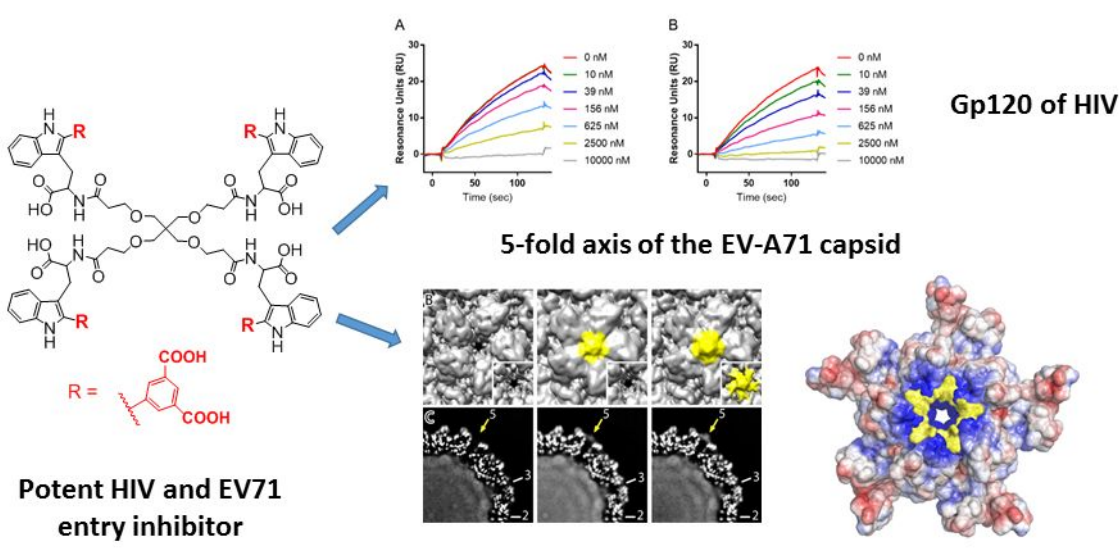




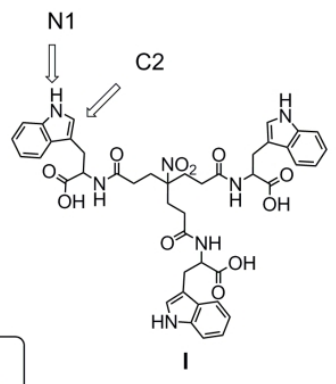

HIV: $\mathrm{EC}_{50}>100 \mu \mathrm{M}$ EV71: $\mathrm{EC}_{50}>120 \mu \mathrm{M}$

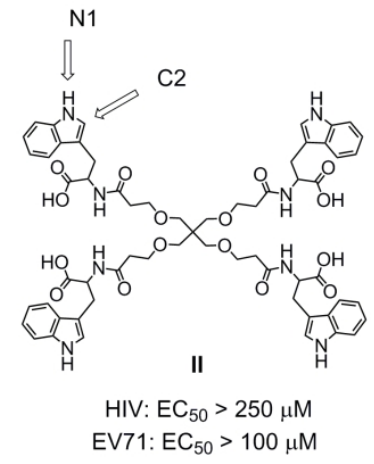

Figure 1. Structures of the prototype pentaerythritol derivative MADAL-385 (1) and "truncated" analogues I and II.

$219 \times 94 \mathrm{~mm}(300 \times 300$ DPI $)$ 
Figure 2. Results of the time-of-drug-addition experiment for compounds 22 and 30 . CD4+ T cells were treated with the compounds at selected times before, during or after infection with HIV-1. 8h post-infection, cells were harvested and p24 was isolated and quantified by means of RT-qPCR. Data for AZT are given as reference. 

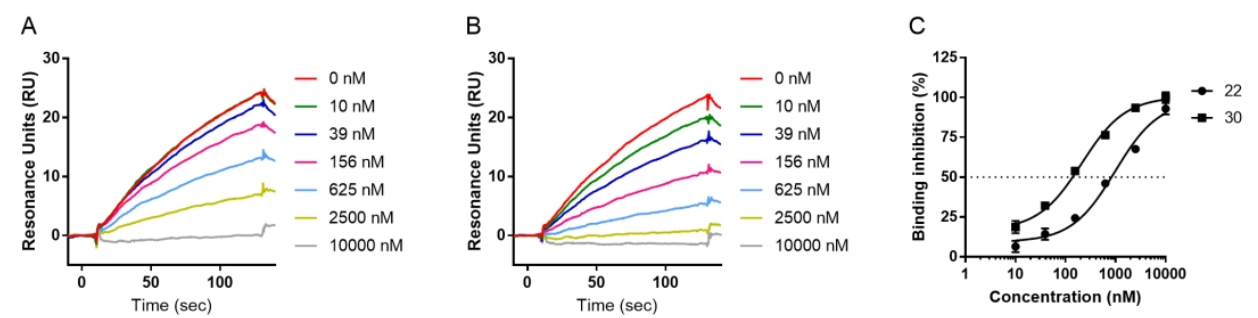

Figure 3. Inhibition of gp120-heparin binding by 22 and 30 as measured by SPR. Biotinylated heparin was captured on a Streptavidin Sensor Chip. Gp120 (10 nM) was mixed with a concentration range of compound 22 (A) or 30 (B). One representative sensorgram per compound out of three independent experiments is shown. Binding levels (RU) were converted into percentage inhibition relative to gp120 binding without compound. Mean (+SEM) and nonlinear fit of three independent experiments are shown (C).

$$
188 \times 53 \mathrm{~mm}(300 \times 300 \text { DPI) }
$$


Figure 4. Time-of-drug-addition for compound 22. RD cells were treated with the compounds at selected times before, during or after infection with EV-A71. 8h post-infection, cells were harvested and intracellular viral RNA was isolated and quantified by means of RT-qPCR. 

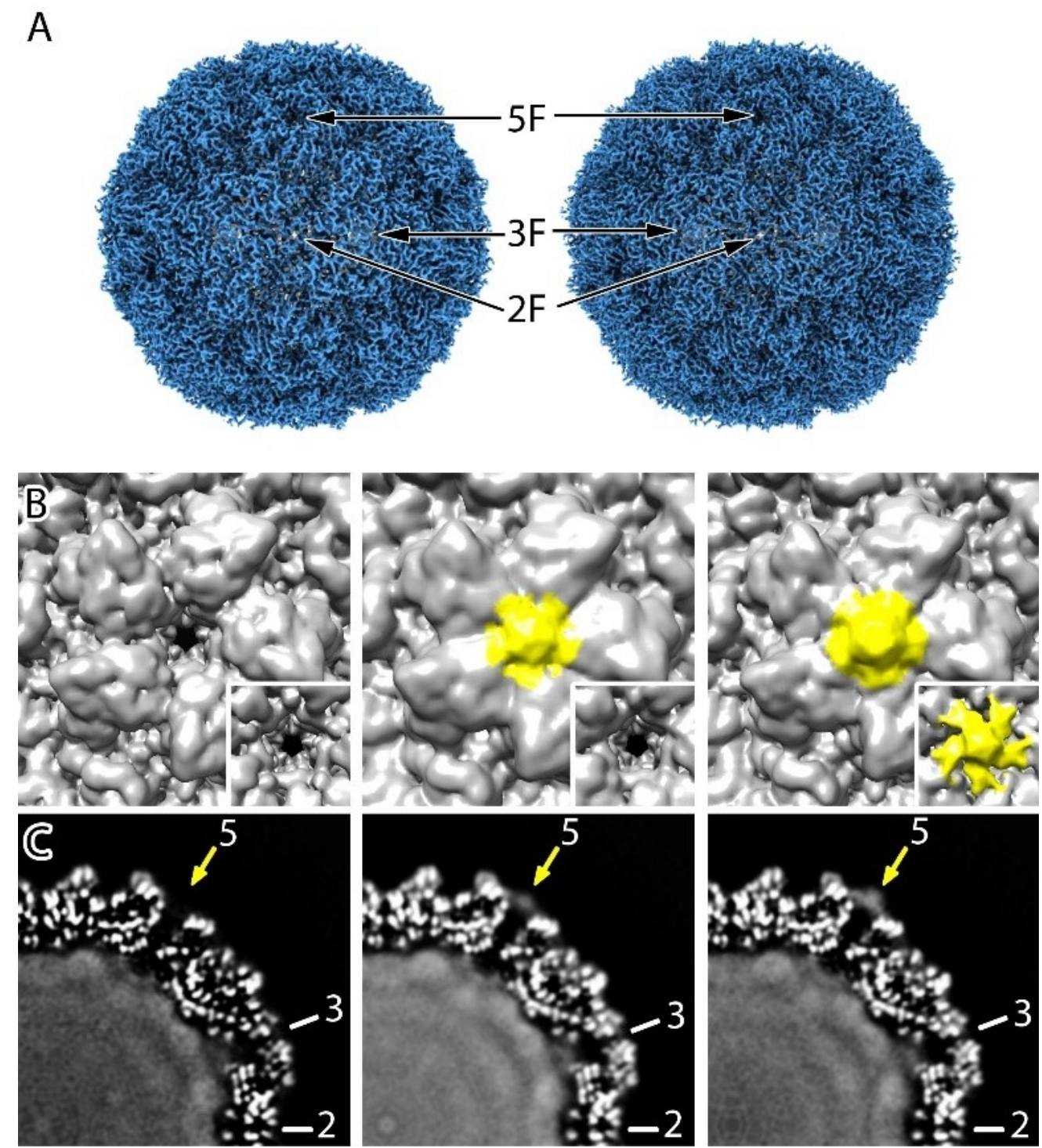

Figure 5. Cryo-EM 3D maps identified the MADAL drugs on the capsid 5-fold vertex. (A) Surface rendering of the sharpened 3D maps for EV-A71 incubated with 22 (left) and 30 (right) showed canonical features of the capsid. Icosahedral symmetry axes were marked with arrows. (B) Comparison of the unsharpened maps (gray) of 22 and 30 complexes with EV-A71 showed extra densities (yellow) on the 5-fold axis. The surface rendered at $1 \square$ and 1.9 (insets) for EV-A71 (left), 22 (middle) and 30 (right). (C) Central sections of the three cryo-EM maps showed extra densities on the 5 -fold-vertex covering the hole at the symmetry axis. Icosahedral symmetry axes were marked.

$89 \times 99 m m(220 \times 220$ DPI $)$ 


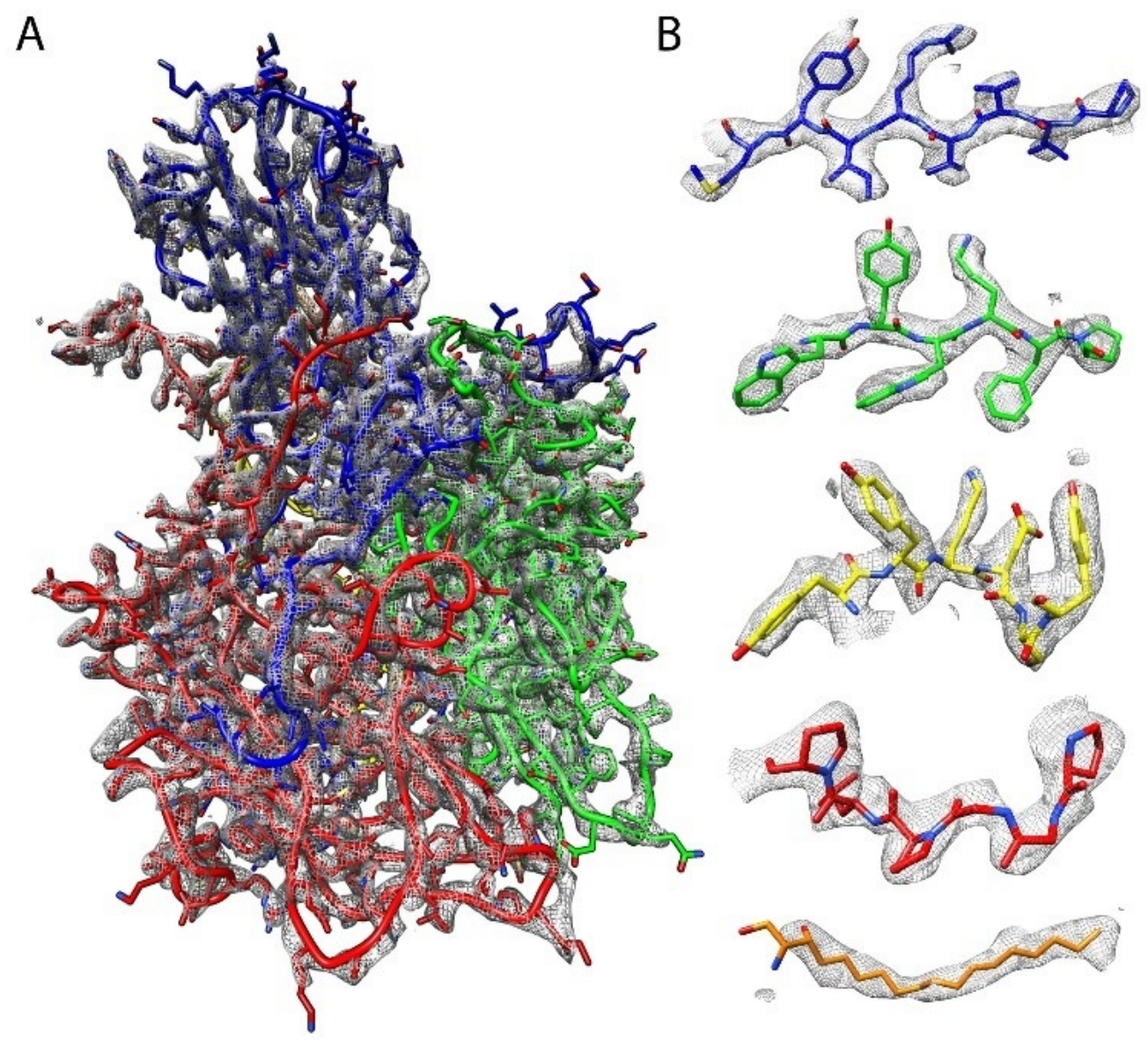

Figure 6. Atomic model built into the cryo-EM map. (A) The atomic models for EV-A71 VP1 (blue), VP2 (green), VP3 (red), VP4 (yellow), and the pocket factor (orange) were built into the cryo-EM map of the virus-30 complex (gray mesh). (B) Representative residues of each VP and the pocket-factor are shown within the corresponding cryo-EM density envelopes to illustrate the quality of the 3D map.

$86 \times 78 \mathrm{~mm}(220 \times 220$ DPI $)$ 
1

2

3

4

5

6

7

8

9

10

11

12

13

14

15

16

17

18

19

20

21

22

23

24

25

26

27

28

29

30

31

32

33

34

35

36

37

38

39

40

41

42

43

44

45

46

47

48

49

50

51

52

53

54

55

56

57

58

59

60
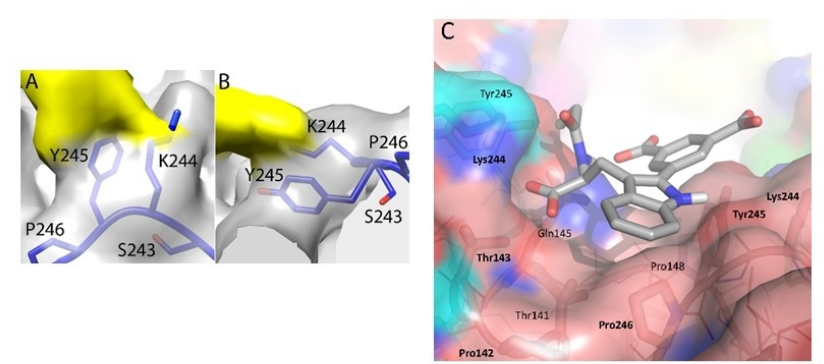

Figure 7. The drug densities are connected to two VP1 residues. (A) The icosahedrally averaged drug density (yellow, 30) was connected mostly with Lys244 and Tyr245 on the VP1 surface (grey). The atomic model of VP1 is depicted as a blue ribbon and the side-chains are shown as sticks. The surface is rendered at $1.9 \square$. Neighboring residues are also labeled. (B) Side-view of the interaction site shows the thin drug density connected to the two VP1 residues. (C) Binding pose proposed by the automated docking program for the substituted Trp residue in 30 at the interface between chains $E$ (cyan) and Q (pink).

$338 \times 190 \mathrm{~mm}(96 \times 96 \mathrm{DPI})$ 
A

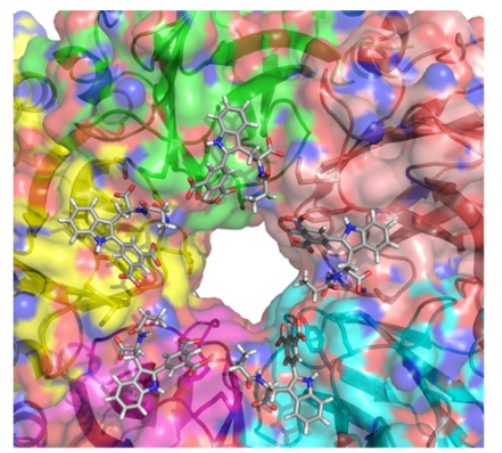

B

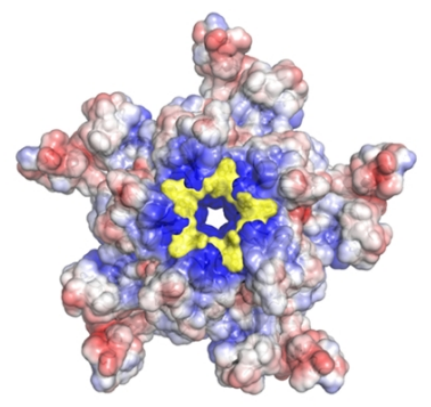

Figure 8. Proposed binding mode of the decorated Trp moiety of 30 around the 5-fold axis of the EV-A71 capsid. (A) A semitransparent surface envelops the five VP1 chains making up the pore. $C$ atoms in chains $A, E, I, M$, and $Q$ are colored in green, cyan, magenta, yellow and pink, respectively. Note that the ethylene linker points towards the central pore. (B) Solvent-accessible surface of the VP1 pentamer color-coded according to the molecular electrostatic potential calculated with APBS (red, $-3.0 \mathrm{kT} / \mathrm{e}$; blue, $+3.0 \mathrm{kT} / \mathrm{e}$ ). The yellow surface filling the subunit interfaces corresponds to the van der Waals surface of the five docked fragments shown in $(A)$.

$338 \times 190 \mathrm{~mm}(96 \times 96 \mathrm{DPI})$ 


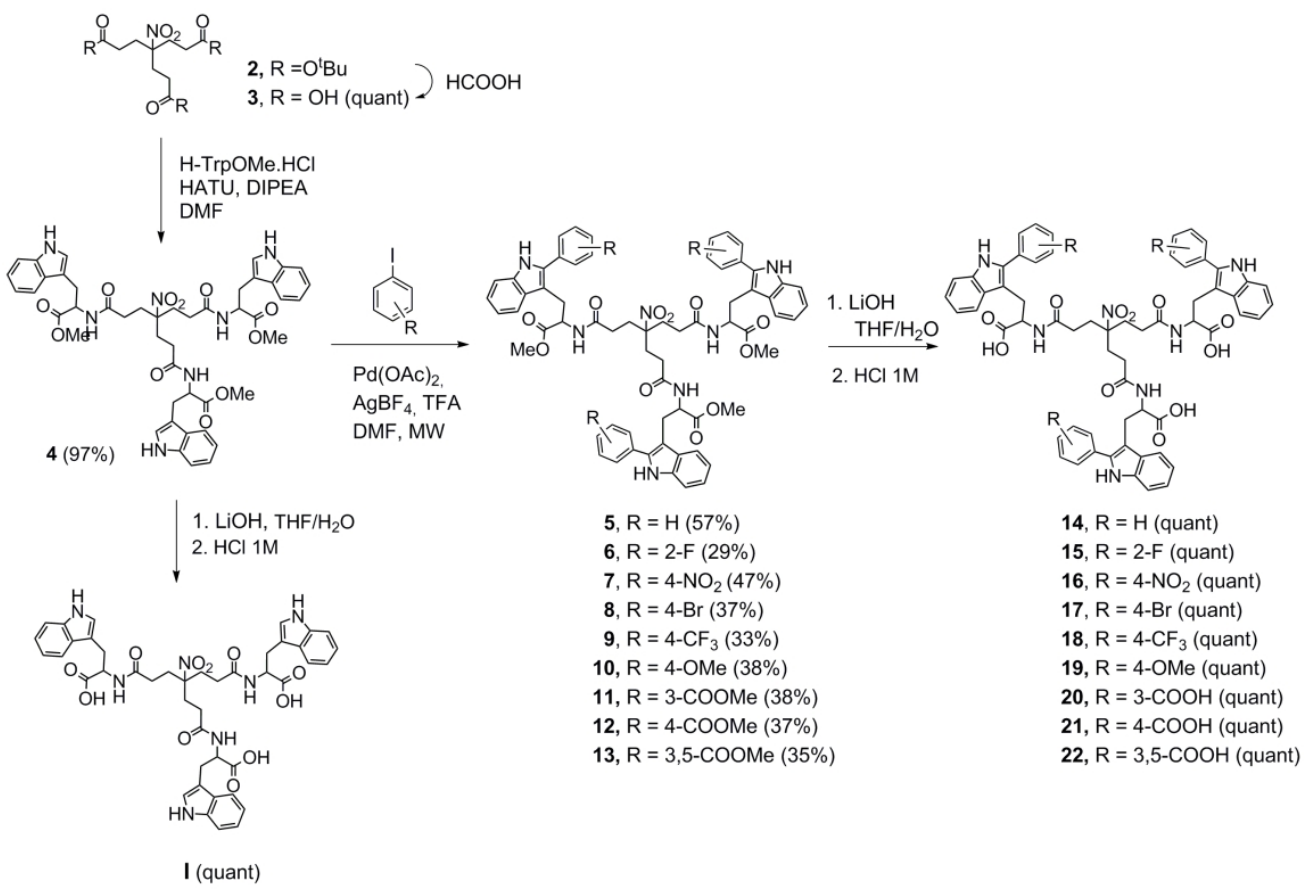

Scheme 1. Synthesis of the tripodal derivatives I and 14-22.

$225 \times 152 \mathrm{~mm}(300 \times 300 \mathrm{DPI})$ 


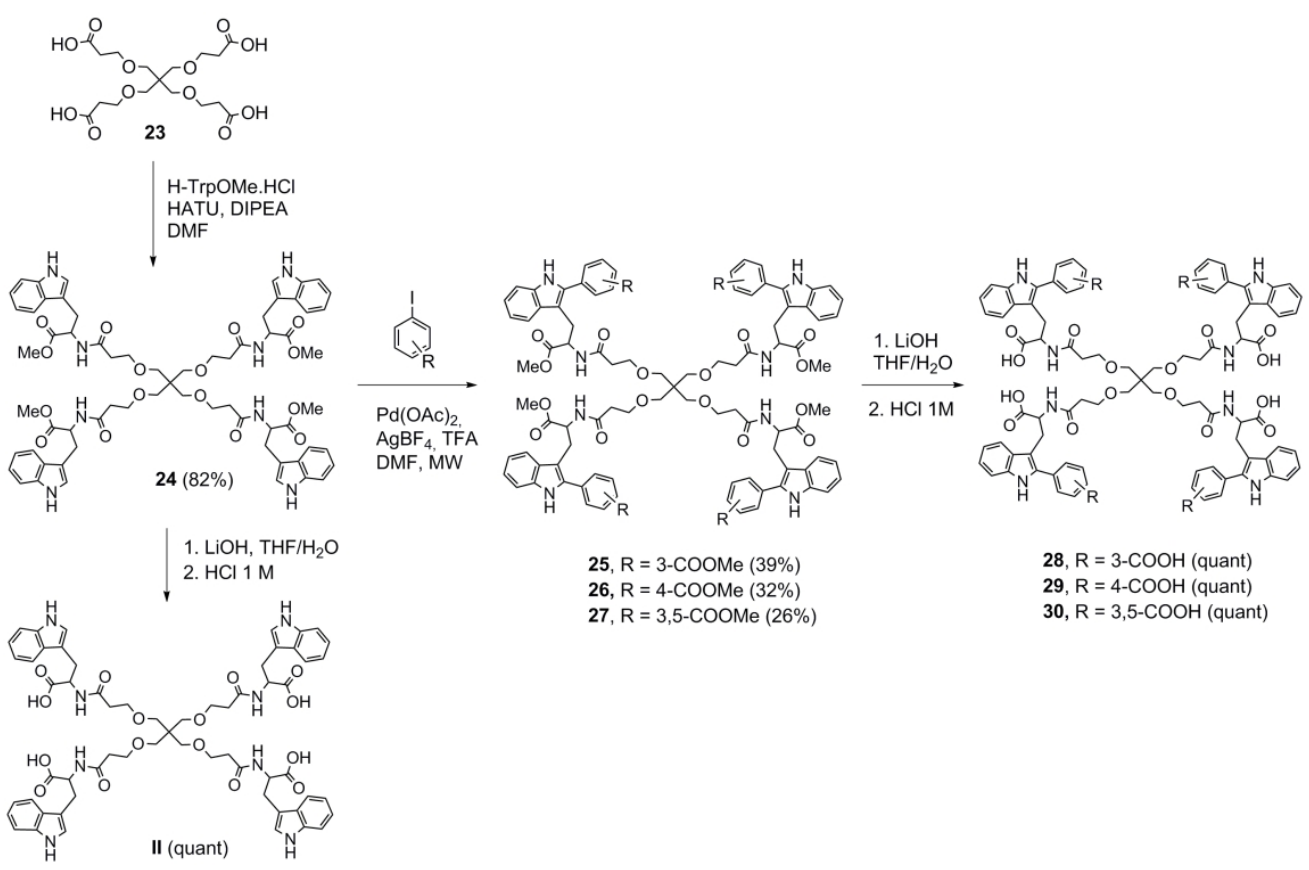

Scheme 2. Synthesis of the tetrapodal derivatives II and 28-30.

$250 \times 164 \mathrm{~mm}(300 \times 300 \mathrm{DPI})$ 

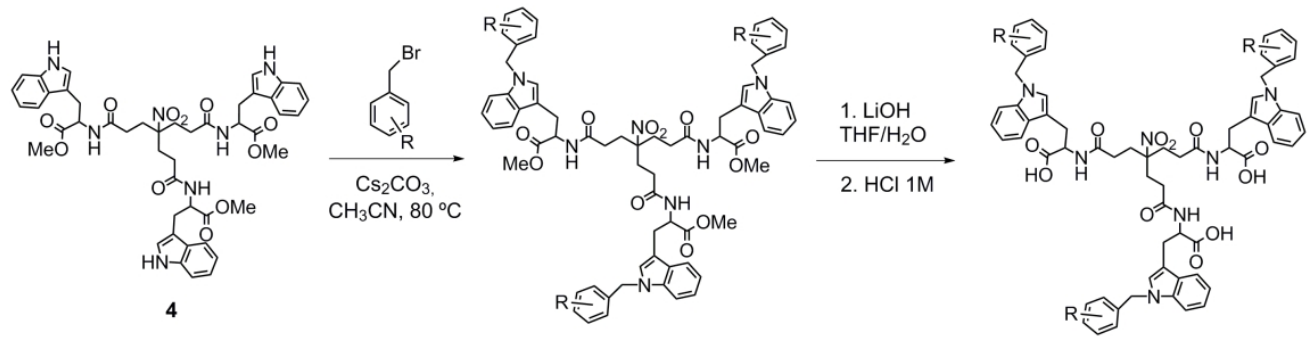

31, $\mathrm{R}=\mathrm{H}(33 \%)$

$32, \mathrm{R}=4-\mathrm{F}(42 \%)$

34, $\mathrm{R}=\mathrm{H}$ (quant)

$35, \mathrm{R}=4-\mathrm{F}$ (quant)

$33, \mathrm{R}=4-\mathrm{COOMe}(33 \%)$

$36, \mathrm{R}=4-\mathrm{COOH}$ (quant)
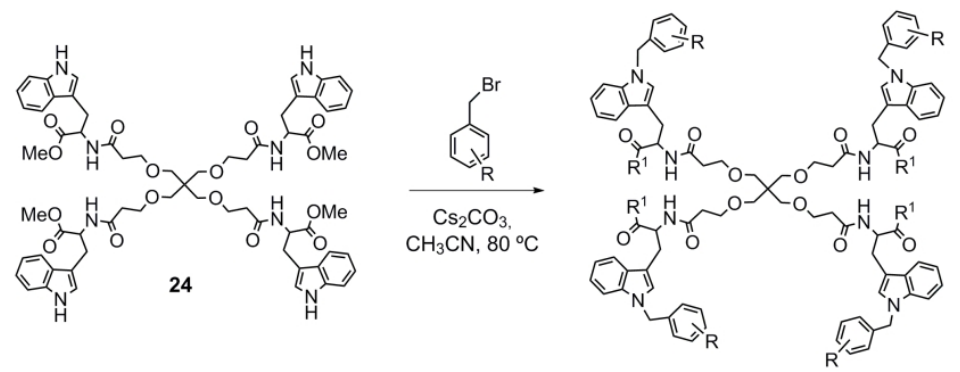

37, $\mathrm{R}=4-\mathrm{COOMe} ; \mathrm{R}^{1}=\mathrm{OMe}(31 \%)$ 1. $\mathrm{LiOH}, \mathrm{THF} / \mathrm{H}_{2} \mathrm{O}$

38, $\mathrm{R}=4-\mathrm{COOH} ; \mathrm{R}^{1}=\mathrm{OH}$ (quant) 2. $\mathrm{HCl} 1 \mathrm{M}$

$240 \times 171 \mathrm{~mm}(300 \times 300$ DPI $)$ 

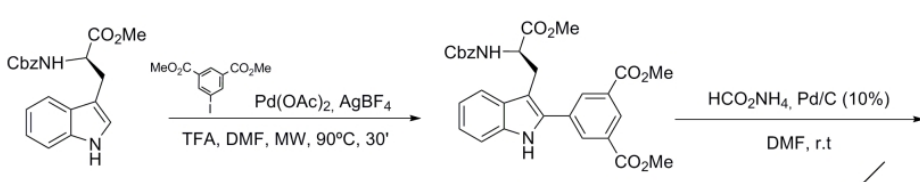

39
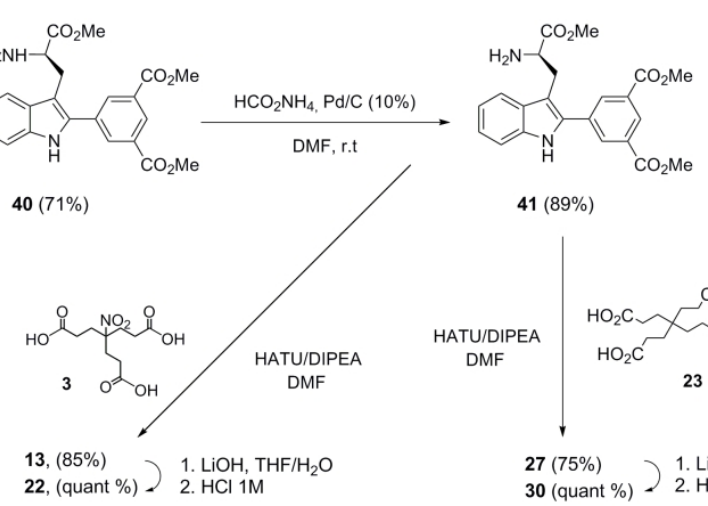

Scheme 4. Alternative synthetic route for the synthesis of 22 and 30.

\section{$243 \times 91 \mathrm{~mm}(300 \times 300 \mathrm{DPI})$}

